Summary of Suspended-Sediment Data for Streams Draining the Chesapeake Bay Waterstied,

Water Years 1952-2002

Scientific Investigations Report 2004-5056

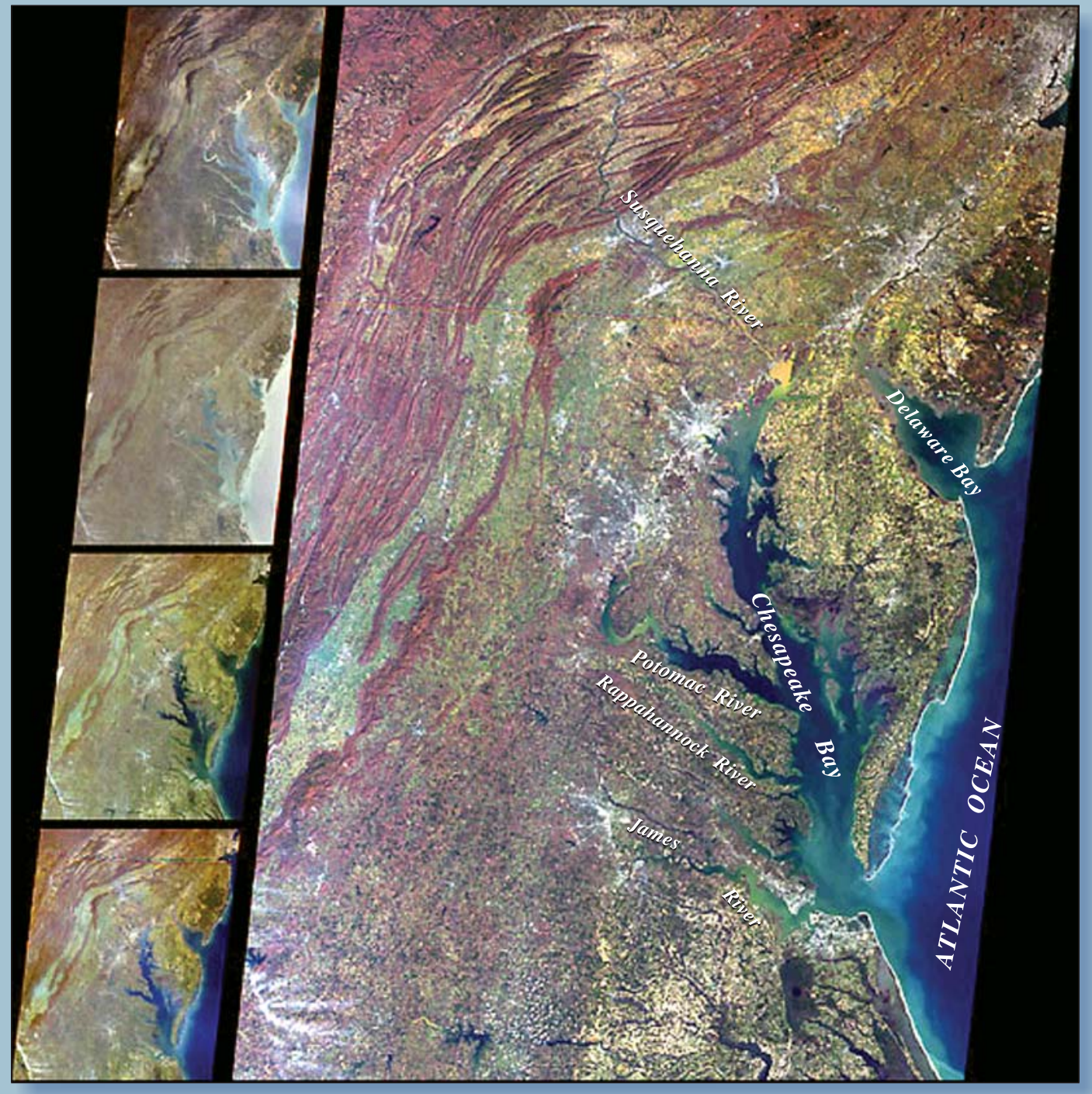


Cover. Multi-angle Imaging SpectroRadiometer (MISR) images of the Chesapeake Bay, Delaware Bay, and the Appalachian Mountains acquired March 24, 2000 during a Terra satellite orbit. (Note the visible sediment export from the Susquehanna River to the Chesapeake Bay.) 


\section{Summary of Suspended-Sediment Data for Streams Draining the Chesapeake Bay Watershed, Water Years 1952-2002}

by Allen C. Gellis, William S.L. Banks, Michael J. Langland, and Sarah K. Martucci

Scientific Investigations Report 2004-5056 


\section{U.S. Department of the Interior}

GALE A. NORTON, Secretary

\section{U.S. Geological Survey}

Charles G. Groat, Director

The use of trade, product, or firm names in this report is for descriptive purposes only and does not imply endorsement by the U.S. Government.

For additional information contact:

District Chief

U.S. Geological Survey

8987 Yellow Brick Road

Baltimore, MD 21237

Copies of this report can be purchased from:

U.S. Geological Survey

Branch of Information Services

Box 25286

Denver, CO 80225-0286 


\section{CONTENTS}

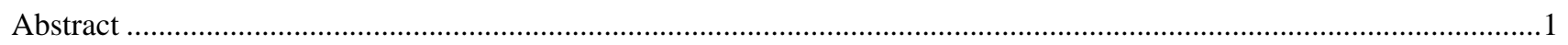

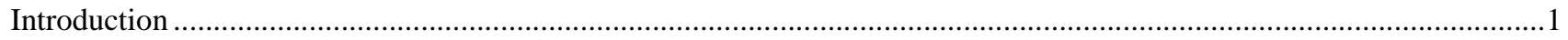

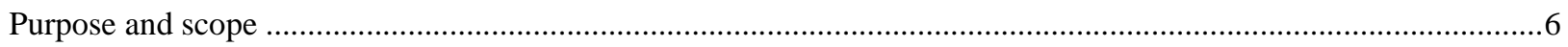

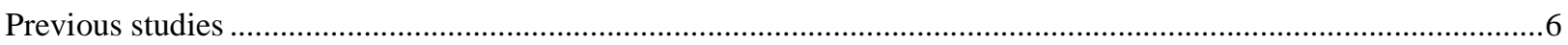

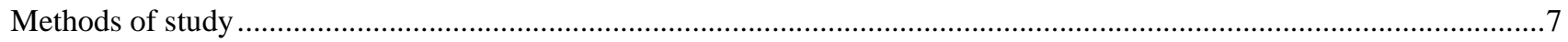

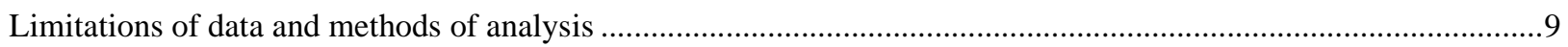

Summary of sediment loads, yields, and discharge-weighted sediment concentrations ..............................................10

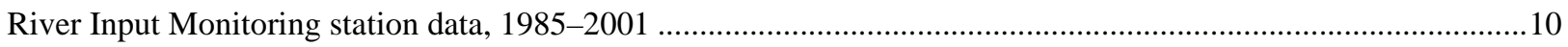

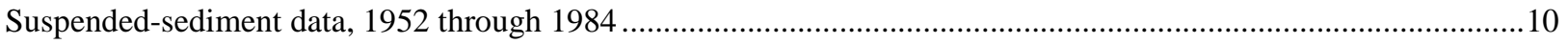

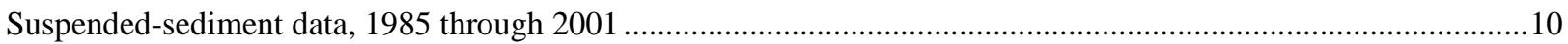

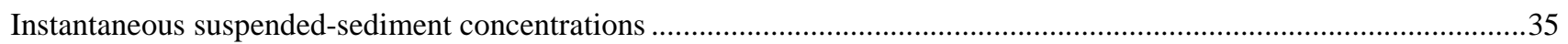

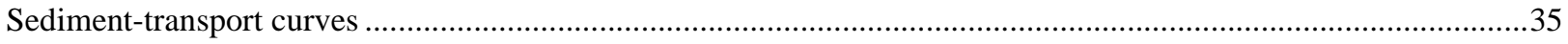

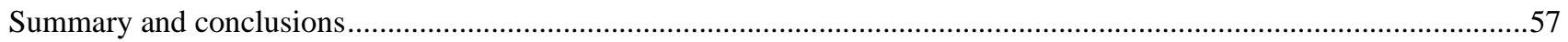

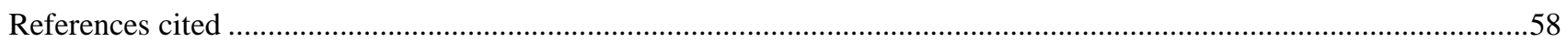

\section{Figures}

1. Map showing location of 65 stations in the Chesapeake Bay Watershed with at least 3 years of water year suspended-sediment load record from 1952 through 2001

2. Graph showing average annual water year suspended-sediment load computed at daily-load stations compared with loads computed with the Estimator program for water years 1973 through 1993

3. Chart showing listing of sediment stations in the Chesapeake Bay Watershed with at least 3 years of record from water years 1952 through 2001

4. Graph showing distribution of drainage areas for 65 sediment stations in the Chesapeake Bay Watershed with at least 3 years of sediment record from 1952 through 2001

5. Graph showing relation of (A) average annual suspended-sediment load to drainage area, (B) average annual suspended-sediment load to mean-daily discharge, (C) average annual sediment yield to drainage area, and (D) average annual discharge-weighted sediment concentration to drainage area for 65 sediment stations in the Chesapeake Bay Watershed with at least 3 years of record from 1952 through 2001

6a-6c. Maps showing:

6a. Average annual suspended-sediment load from 1985 through 2001 for nine River Input Monitoring (RIM) stations in the Chesapeake Bay Watershed.

6b. Average annual sediment yield from 1985 through 2001 for nine River Input Monitoring (RIM) stations in the Chesapeake Bay Watershed

6c. Average annual discharge-weighted sediment concentration from 1985 through 2001 for nine River Input Monitoring (RIM) stations in the Chesapeake Bay Watershed 
Figures-Continued

7a-7c. Maps showing:

7a. Average annual suspended-sediment load from 1952 through 1984 for 43 stations in the

Chesapeake Bay Watershed with at least 3 years of record

7b. Average annual sediment yield from 1952 through 1984 for 43 stations in the Chesapeake

Bay Watershed with at least 3 years of record

7c. Average annual discharge-weighted sediment concentration from 1952 through 1984 for 43 stations in the Chesapeake Bay Watershed with at least 3 years of record

8a-8c. Maps showing:

8a. Average annual suspended-sediment load from 1985 through 2001 for 35 stations in the

Chesapeake Bay Watershed with at least 3 years of record

8b. Average annual sediment yield from 1985 through 2001 for 35 stations in the Chesapeake

Bay Watershed with at least 3 years of record

8c. Average annual discharge-weighted sediment concentration from 1985 through 2001 for

35 stations in the Chesapeake Bay Watershed with at least 3 years of record

9. Map showing location of stations in the Chesapeake Bay Watershed used in the analysis of instantaneous suspended-sediment concentration on percentiles and sediment-transport curves from 1985 through 2002

10a-10c. Maps showing:

10a. The $10^{\text {th }}$ percentile of suspended-sediment concentration for 51 stations draining the Chesapeake Bay Watershed with at least 3 years of record and at least 10 samples in a given year

10b. The median ( $50^{\text {th }}$ percentile) of suspended-sediment concentration for 51 stations draining the Chesapeake Bay Watershed with at least 3 years of record and at least 10 samples in a given year

10c. The $90^{\text {th }}$ percentile of suspended-sediment concentration for 51 stations draining the Chesapeake Bay Watershed with at least 3 years of record and at least 10 samples in a given year

11a-e. Graphs showing sediment-transport curves for the stream-gaging stations on/in the:

a. Eastern Shore of Maryland and Delaware ……....................................................................................

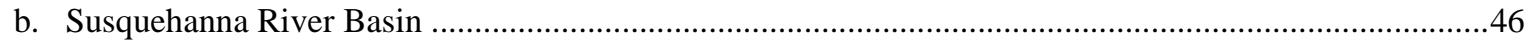

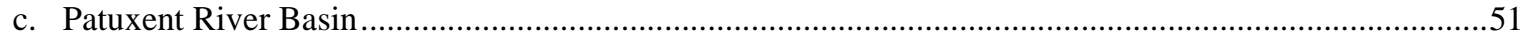

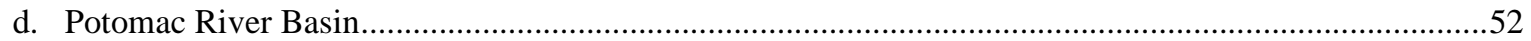

e. Pamunkey and Mattaponi River Basins …………...................................................................................54

12a-h. Graphs showing sediment-transport curves normalized by drainage area separated into eight classes of drainage area:

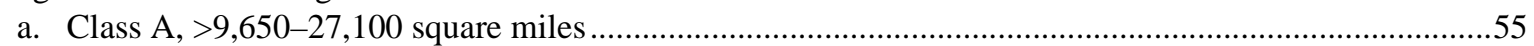

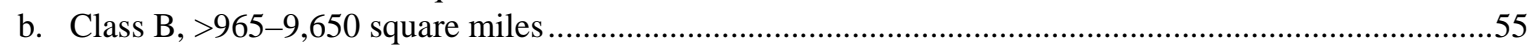

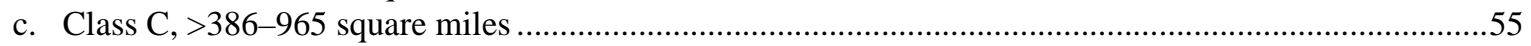

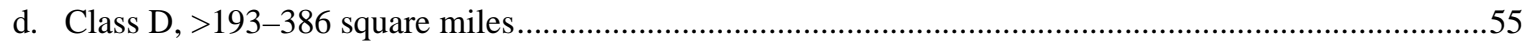

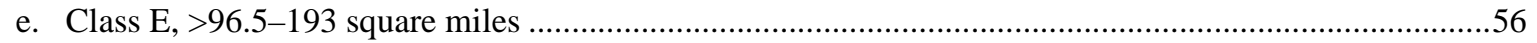

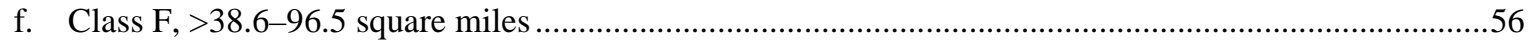

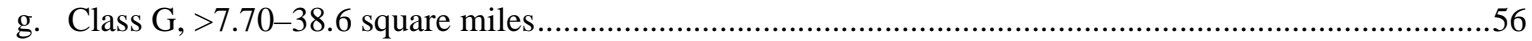

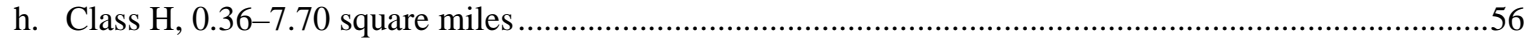




\section{Tables}

1. Period of record for suspended-sediment loads and instantaneous suspended-sediment concentrations used in this report, drainage areas of collection stations, and sources used in the computation of suspended-sediment loads

2. Summary of sediment data collected from River Input Monitoring stations, 1985 through 2001 ........................18

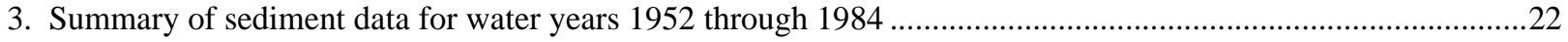

4. Rankings of sediment loads, yields, and discharge-weighted sediment concentrations, from highest (1) to lowest (43) values, for stations operating from water years 1952 through 1984 ........................................26

5. Summary of sediment data for water years 1985 through 2001 ..........................................................................30

6. Rankings of sediment loads, yields, and discharge-weighted sediment concentrations, from highest (1) to lowest (43) values, for stations operating from water years 1985 through 2001 ........................................34

7. Summary of instantaneous suspended-sediment concentration data for stations used in this report for water years 1985 through 2002, including $10^{\text {th }}, 50^{\text {th }}$, and $90^{\text {th }}$ percentiles ...................................................36

8. Rankings of $10^{\text {th }}, 50^{\text {th }}$, and $90^{\text {th }}$ percentiles of suspended-sediment concentrations from highest (1) to lowest (51) values. 


\section{Conversion Factors}

\begin{tabular}{|c|c|c|}
\hline Multiply & By & To obtain \\
\hline \multicolumn{3}{|c|}{ Length } \\
\hline $\begin{array}{l}\text { foot }(\mathrm{ft}) \\
\text { mile (mi) } \\
\text { mile, nautical (nmi) } \\
\text { yard (yd) }\end{array}$ & $\begin{array}{l}0.3048 \\
1.609 \\
1.852 \\
0.9144\end{array}$ & $\begin{array}{l}\text { meter } \\
\text { kilometer } \\
\text { kilometer } \\
\text { meter }\end{array}$ \\
\hline \multicolumn{3}{|c|}{ Area } \\
\hline $\begin{array}{l}\text { acre } \\
\text { acre } \\
\text { acre } \\
\text { acre } \\
\text { square foot }\left(\mathrm{ft}^{2}\right) \\
\text { square foot }\left(\mathrm{ft}^{2}\right) \\
\text { square inch }\left(\mathrm{in}^{2}\right) \\
\text { section }\left(640 \mathrm{acres}^{2} \text { or } 1 \text { square mile) }\right. \\
\text { square mile }\left(\mathrm{mi}^{2}\right) \\
\text { square mile }\left(\mathrm{mi}^{2}\right)\end{array}$ & $\begin{array}{l}4,047 \\
0.4047 \\
0.4047 \\
0.004047 \\
929.0 \\
0.09290 \\
6.452 \\
259.0 \\
259.0 \\
2.590\end{array}$ & $\begin{array}{l}\text { square meter } \\
\text { hectare } \\
\text { square hectometer } \\
\text { square kilometer } \\
\text { square centimeter } \\
\text { square meter } \\
\text { square centimeter } \\
\text { square hectometer } \\
\text { hectare } \\
\text { square kilometer }\end{array}$ \\
\hline \multicolumn{3}{|c|}{ Flow rate } \\
\hline $\begin{array}{l}\text { cubic foot per second }\left(\mathrm{ft}^{3} / \mathrm{s}\right) \\
\text { cubic foot per second } \\
\text { per square mile }\left[\left(\mathrm{ft}^{3} / \mathrm{s}\right) / \mathrm{mi}^{2}\right]\end{array}$ & $\begin{array}{l}0.02832 \\
0.01093\end{array}$ & $\begin{array}{r}\text { cubic meter per second } \\
\text { cubic meter per second } \\
\text { per square kilometer }\end{array}$ \\
\hline \multicolumn{3}{|c|}{ Mass } \\
\hline ton, short $(2,000 \mathrm{lb})$ & 0.9072 & megagram \\
\hline ton, long $(2,240 \mathrm{lb})$ & 1.016 & megagram \\
\hline ton per day (ton/d) & 0.9072 & metric ton per day \\
\hline ton per day (ton/d) & 0.9072 & megagram per day \\
\hline $\begin{array}{l}\text { ton per day per } \\
\text { square mile }\left[(\text { ton } / \mathrm{d}) / \mathrm{mi}^{2}\right]\end{array}$ & 0.3503 & $\begin{array}{l}\text { megagram per day } \\
\text { per square kilometer }\end{array}$ \\
\hline ton per year (ton/yr) & 0.9072 & megagram per year \\
\hline ton per year (ton/yr) & 0.9072 & metric ton per year \\
\hline
\end{tabular}

Concentrations of chemical constituents in water are given either in milligrams per liter (mg/L).

Note to USGS users: Use of hectare (ha) as an alternative name for square hectometer $\left(\mathrm{hm}^{2}\right)$ is restricted to the measurement of small land or water areas. Use of liter (L) as a special name for cubic decimeter $\left(\mathrm{dm}^{3}\right)$ is restricted to the measurement of liquids and gases. No prefix other than milli should be used with liter. Metric ton ( $\mathrm{t}$ ) as a name for megagram (Mg) should be restricted to commercial usage, and no prefixes should be used with it. 


\title{
Summary of Suspended-Sediment Data for Streams Draining the Chesapeake Bay Watershed, Water Years 1952-2002
}

\author{
By Allen C. Gellis, William S.L. Banks, Michael J. Langland, and Sarah K. Martucci
}

\begin{abstract}
U.S. Geological Survey suspended-sediment data from 1952 to 2002 from selected stream-gaging stations draining the nontidal parts of the Chesapeake Bay Watershed were summarized to identify areas in the Watershed with high suspended-sediment loads, yields, and concentrations. The suspended-sediment load data were separated into two periods, 1952-1984 and 1985-2001. In 1985, the Chesapeake Bay Program began recommending sediment regulations, so 1985 represents an important break in the data. The instantaneous suspended-sediment concentration data were examined for the period 1985-2002.

Suspended-sediment load data collected from

51 stations were separated into classes by drainage-area size. Five of the eight drainage-area classes showed that streams draining the Susquehanna River Basin had the highest suspended-sediment concentrations. Three of the Susquehanna River Basin drainage-area classes were in the Conestoga River Basin. Agriculture is the dominant land use in the Conestoga River Basin and may be an important source of sediment leading to the high sediment yields and instantaneous suspended-sediment concentrations, but further research is needed to quantify the importance of agriculture in relation to other sources of sediment in the Conestoga River Basin.
\end{abstract} 43 stations from 1952-1984, with a minimum of 3 years of record, indicated that the two highest average annual suspended-sediment loads were for stations on the main stem of the Potomac and Susquehanna Rivers. The highest average annual sediment yields and discharge-weighted sediment concentrations were for streams draining the metropolitan Washington, D.C. area, possibly related to urbanization. Data from 1985 through 2001 that were collected from 35 stations with a minimum of 3 years of record showed that the highest average annual suspended-sediment loads were also on the main stem of the Potomac and Susquehanna Rivers. Four of the six highest average annual sediment yields and dischargeweighted sediment concentrations for 1985-2001 were for stations draining to the Conestoga River, a tributary of the Susquehanna River.

Examination of percentiles $\left(10^{\text {th }}, 50^{\text {th }}\right.$, and $90^{\text {th }}$ ) of instantaneous suspended-sediment concentrations for 51 stations with a minimum of 3 years of data and at least 10 samples in a year indicated that streams that drain to the Conestoga River had the highest suspended-sediment concentrations. Sediment-transport curves for the

\section{Introduction}

The Chesapeake Bay is the largest estuary in the United States, draining over 64,000 $\mathrm{mi}^{2}$ (square miles). Much of the habitat in the Chesapeake Bay is degraded because of sediment (Langland and others, 1995). Suspended sediment in the water column can decrease the light available for submerged aquatic vegetation (SAV), and excess sediment can bury benthic habitats. Nutrients and toxic materials that contaminate habitats can also attach to suspended sediment (Darrell and others, 1999). Goals to reduce sediment loads by the year 2010 have been established by the U.S. Environmental Protection Agency (USEPA). To achieve these goals and reduce suspended-sediment loads and suspended-sediment concentrations in the Chesapeake Bay, identification of source areas of sediment is necessary. Watershed sediment sources can be separated into sediment originating from upland land uses (such as agriculture, mining, and construction) and sediment eroded from channel corridors (such as the channel bed and banks).

The U.S. Geological Survey (USGS) collected suspended sediment to determine daily sediment loads at selected stream-gaging stations in the Chesapeake Bay Watershed from water years (WY) 1952 through 1999 (fig. 1 , table 1 ). A WY is defined as October 1 of the previous 


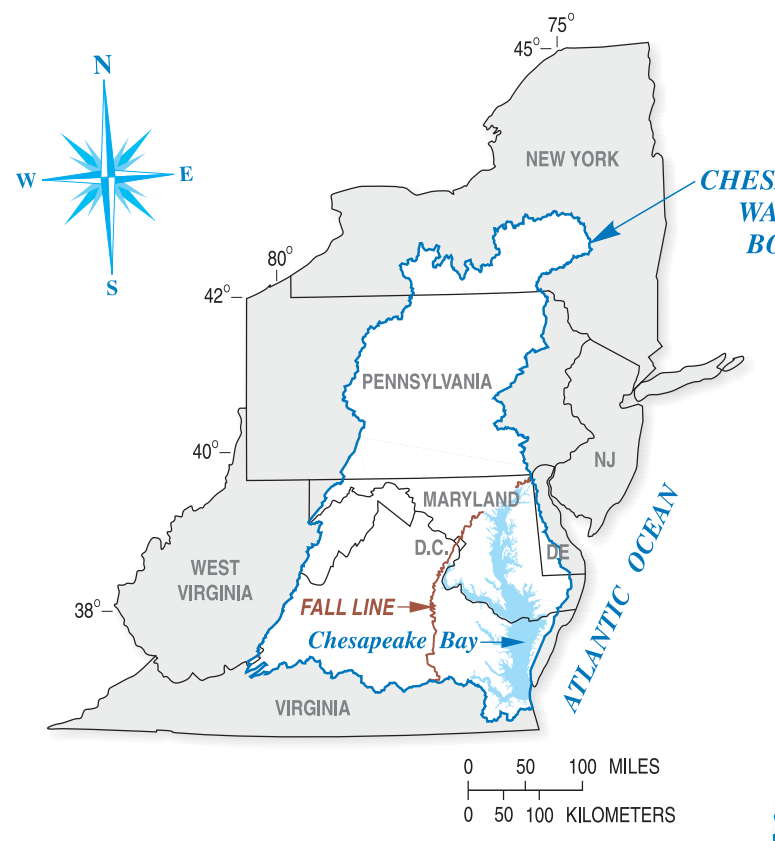

EXPLANATION

SEDIMENT DATA SOURCE

1567500 USGS DAILY-LOAD STATION AND IDENTIFICATION NUMBER

1562000 ESTIMATOR STATION AND IDENTIFICATION NUMBER

1570500 O USGS DAILY-LOAD AND ESTIMATOR STATION AND IDENTIFICATION NUMBER

\section{CHESAPEAKE BAY WATERSHED}

BASINS

SUSQUEHANNA RIVER

WESTERN SHORE

PATUXENT RIVER

POTOMAC RIVER

RAPPAHANNOCK RIVER

YORK RIVER

JAMES RIVER

EASTERN SHORE

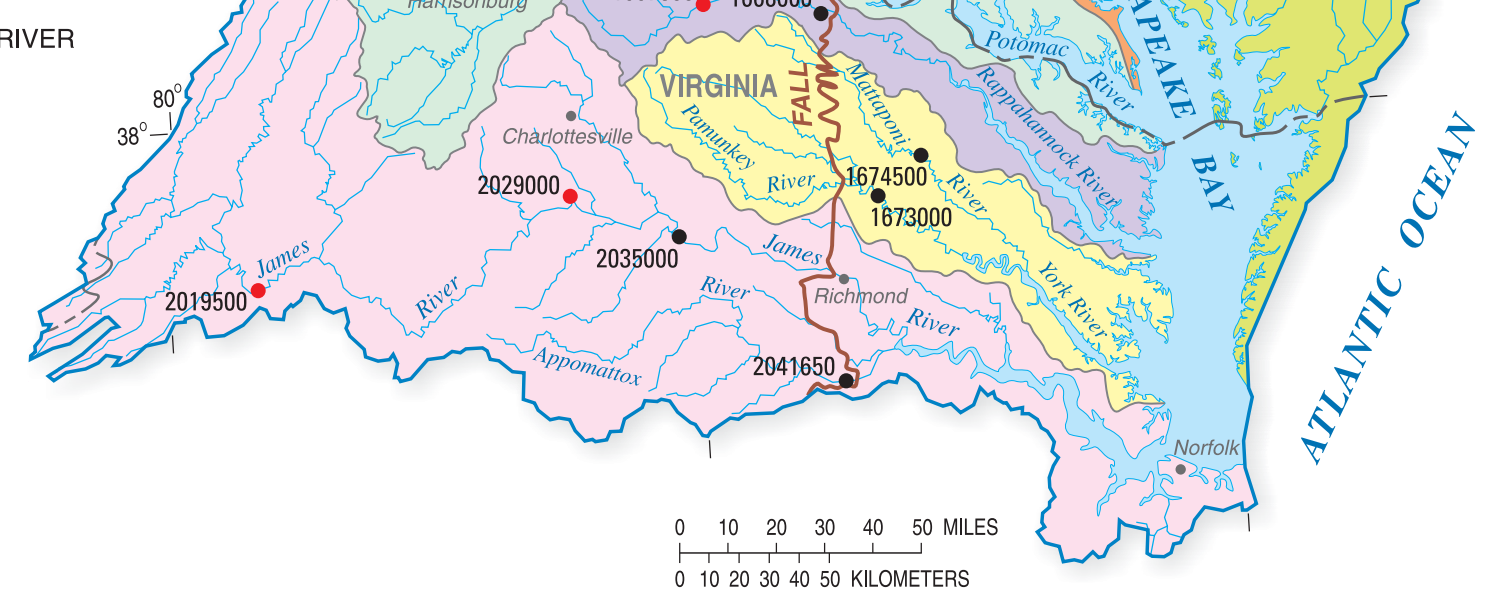

Figure 1. Location of 65 stations in the Chesapeake Bay Watershed with at least 3 years of water year suspended-sediment load record from 1952 through 2001. (The data source for computation of suspended sediment is shown as either reported from daily-load stations or Estimator stations.) 
Table 1. Period of record for suspended-sediment loads and instantaneous suspended-sediment concentrations used in this report, drainage areas of collection stations, and sources used in the computation of suspended-sediment loads

[USGS daily refers to daily load sediment stations, Estimator is sediment data from the ESTIMATOR model, and RIM is sediment data from the River Input Monitoring stations. Water Year is from October 1 of the previous year to September 30 of the current year]

\begin{tabular}{|c|c|c|c|c|c|}
\hline Station name & $\begin{array}{l}\text { Station } \\
\text { identification } \\
\text { number }\end{array}$ & $\begin{array}{l}\text { Period of } \\
\text { record for } \\
\text { annual loads } \\
\text { (water year) }\end{array}$ & $\begin{array}{l}\text { Annual load } \\
\text { computation } \\
\text { sources }\end{array}$ & \begin{tabular}{|l} 
Period of \\
record for \\
instantaneous \\
suspended- \\
sediment data \\
(water year)
\end{tabular} & $\begin{array}{l}\text { Drainage } \\
\text { area, } \\
\text { square } \\
\text { miles }\end{array}$ \\
\hline \multicolumn{6}{|l|}{ Eastern Shore } \\
\hline Nassawango Creek near Snow Hill, MD & 01485500 & & & 1999-2002 & 44.9 \\
\hline Nanticoke River near Bridgeville, DE & 01487000 & & & 1994-2002 & 75.4 \\
\hline Choptank River near Greensboro, MD & 01491000 & & $\begin{array}{l}\text { Estimator/ } \\
\text { USGS daily/ } \\
\text { RIM }\end{array}$ & 1985-2002 & 113 \\
\hline Chesterville Branch near Crumpton, MD & 01493112 & $1972-2001$ & & 1996-2002 & 6.12 \\
\hline \multicolumn{6}{|l|}{ Susquehanna River } \\
\hline Corey Creek near Mainesburg, PA & 01516500 & $\begin{array}{l}\text { 1955, 1957, 1960- } \\
1967\end{array}$ & USGS daily & & 12.2 \\
\hline Elk Run near Mainesburg, PA & 01517000 & $\begin{array}{l}\text { 1955-1956, 1958, } \\
1960-1962,1966- \\
1967\end{array}$ & USGS daily & & 10.2 \\
\hline Tioga River at Tioga, PA & 01518000 & $1973-1978$ & Estimator & & 282 \\
\hline Tioga River at Lindley, NY & 01520500 & $1975-1980$ & USGS daily & & 771 \\
\hline Chemung River at Chemung, NY & 01531000 & 1975-1977 & USGS daily & & 2,506 \\
\hline Susquehanna River at Towanda, PA & 01531500 & 1985-1996 & Estimator & 1985-1993 & 7,797 \\
\hline Susquehanna River at Danville, PA & 01540500 & 1975-1996 & $\begin{array}{l}\text { Estimator/ } \\
\text { USGS daily }\end{array}$ & 1985-1995 & 11,220 \\
\hline Young Womans Creek near Renovo, PA & 01545600 & $\begin{array}{l}\text { 1973-1979, 1981, } \\
\text { 1983, 1985-1992 }\end{array}$ & Estimator & & 46.2 \\
\hline Wilson Creek above Sand Run near Antrim, PA & 01548408 & $\begin{array}{l}\text { 1979-1981, 1985- } \\
1996\end{array}$ & USGS daily & & 6,847 \\
\hline Blockhouse Creek Tributary at Liberty, PA & 01549100 & $1973-1977$ & USGS daily & & 1.08 \\
\hline Blockhouse Creek at Buttonwood, PA & 01549300 & 1973-1977 & USGS daily & & 22.3 \\
\hline Steam Valley Run at Buttonwood, PA & 01549350 & $1973-1977$ & USGS daily & & 5.34 \\
\hline Blockhouse Creek near English Center, PA & 01549500 & 1973-1977 & USGS daily & & 37.7 \\
\hline West Branch Susquehanna River at Lewisburg, PA & 01553500 & 1975-1984 & USGS daily & 1985-1995 & 6,847 \\
\hline Susquehanna River at Sunbury, PA & 01554000 & 1973-1977 & Estimator & & 18,306 \\
\hline East Mahantango Creek at Klingerstown, PA & 01555400 & & & $1993-2000$ & 44.7 \\
\hline Bobs Creek near Pavia, PA & 01559795 & & & $1993-2000$ & 16.6 \\
\hline Raystown Branch Juniata River at Saxton, PA & 01562000 & 1988-1992 & Estimator & $1985-1993$ & 756 \\
\hline Juniata River at Newport, PA & 01567000 & 1985-1996 & Estimator & & 3,355 \\
\hline Bixler Run near Loysville, PA & 01567500 & $1955-1970$ & USGS daily & & 15 \\
\hline Sherman Creek at Shermans Dale, PA & 01568000 & 1985-1996 & Estimator & 1985-1995 & 207 \\
\hline Conodoguinet Creek near Hogestown, PA & 01570000 & & & 1985-2002 & 470 \\
\hline Conodoguinet Creek Tributary No. 1 near Enola, PA & 01570100 & 1971-1976 & USGS daily & & 0.77 \\
\hline Conodoguinet Creek Tributary No. 2 near Enola, PA & 01570200 & $1973-1976$ & USGS daily & & 0.76 \\
\hline Conodoguinet Creek Tributary No. 2A near Enola, PA & 01570230 & $1973-1976$ & USGS daily & & 0.7 \\
\hline Conodoguinet Creek Tributary No. 2B near Enola, PA & 01570260 & $1973-1976$ & USGS daily & & 0.65 \\
\hline Conodoguinet Creek Tributary No. 3 near Enola, PA & 01570300 & $1970-1976$ & USGS daily & & 0.38 \\
\hline Susquehanna River at Harrisburg, PA & 01570500 & $\begin{array}{l}\text { 1964-1966, 1968, } \\
\text { 1972-1991 }\end{array}$ & $\begin{array}{l}\text { Estimator/ } \\
\text { USGS daily }\end{array}$ & & 24,100 \\
\hline Paxton Creek near Penbrook, PA & 01571000 & & & $1985-1994$ & 11.2 \\
\hline Cedar Run at Eberlys Mill, PA & 01571490 & & & 1993-1997 & 12.6 \\
\hline
\end{tabular}


Table 1. Period of record for suspended-sediment loads and instantaneous suspended-sediment concentrations used in this report, drainage areas of collection stations, and sources used in the computation of suspended-sediment loads-Continued

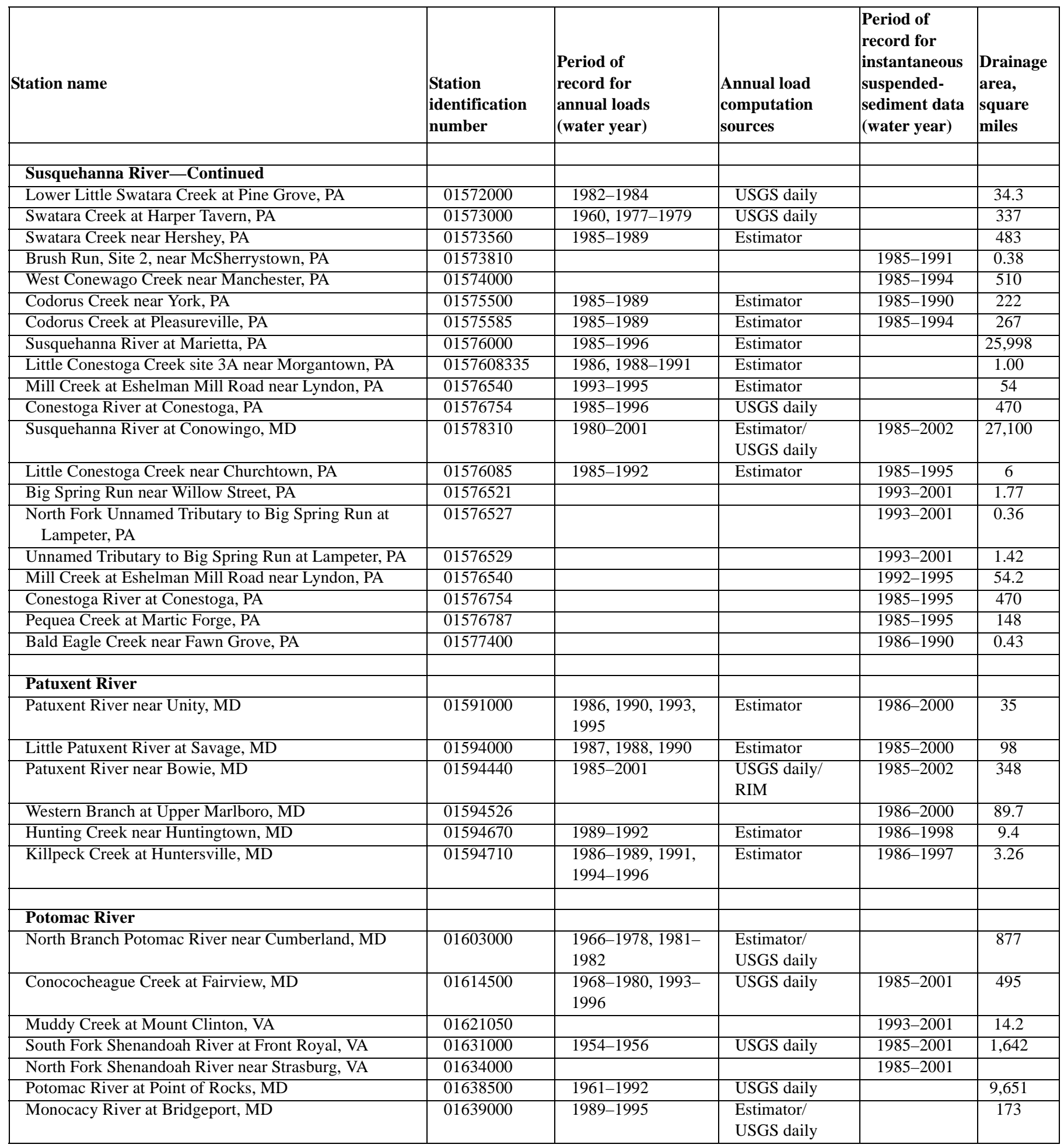


Table 1. Period of record for suspended-sediment loads and instantaneous suspended-sediment concentrations used in this report, drainage areas of collection stations, and sources used in the computation of suspended-sediment loads-Continued

\begin{tabular}{|c|c|c|c|c|c|}
\hline Station name & $\begin{array}{l}\text { Station } \\
\text { identification } \\
\text { number }\end{array}$ & $\begin{array}{l}\text { Period of } \\
\text { record for } \\
\text { annual loads } \\
\text { (water year) }\end{array}$ & $\begin{array}{l}\text { Annual load } \\
\text { computation } \\
\text { sources }\end{array}$ & $\begin{array}{l}\text { Period of } \\
\text { record for } \\
\text { instantaneous } \\
\text { suspended- } \\
\text { sediment data } \\
\text { (water year) }\end{array}$ & $\begin{array}{l}\text { Drainage } \\
\text { area, } \\
\text { square } \\
\text { miles }\end{array}$ \\
\hline \multicolumn{6}{|l|}{ Potomac River-Continued } \\
\hline $\begin{array}{l}\text { Monocacy River at Reichs Ford Bridge near } \\
\text { Frederick, MD }\end{array}$ & 01643020 & $\begin{array}{l}1961-1966,1968- \\
1983,1985-1992\end{array}$ & USGS daily & & 817 \\
\hline Smilax Branch at Reston, VA & 01644295 & $1972-1975$ & USGS daily & & 0.32 \\
\hline Snakeden Branch at Reston, VA & 01645784 & $1974-1978$ & USGS daily & & 0.79 \\
\hline Potomac River at Chain Bridge at Washington, D.C. ${ }^{1}$ & 01646580 & 1979-2001 & $\begin{array}{l}\text { Estimator/ } \\
\text { USGS daily/ } \\
\text { RIM }\end{array}$ & 1985-2002 & 11,570 \\
\hline North Branch Rock Creek near Norbeck, MD & 01647720 & $1972-1976$ & Estimator & & 9.73 \\
\hline North Branch Rock Creek near Rockville, MD & 01647740 & 1968-1977 & USGS daily & & 12.5 \\
\hline Northwest Branch Anacostia River near Colesville, MD & 01650500 & $1963-1975$ & USGS daily & & 21.1 \\
\hline Accotink Creek near Annandale, VA & 01654000 & & & 1985-2001 & 23.5 \\
\hline Cedar Run near Aden, VA & 01656100 & & & $\begin{array}{l}\text { 1985-1988, } \\
1996-1999\end{array}$ & 155 \\
\hline Cedar Run at Route 646 near Aden, VA & 01656120 & 1997-1999 & USGS daily & $1996-2000$ & 175 \\
\hline South Fork Quantico Creek near Independent Hill, VA & 01658500 & & & 1985-2001 & 7.64 \\
\hline Cannon Creek near Garrisonville, VA & 01660380 & & & 1994-1997 & 10.2 \\
\hline Beaverdam Run near Garrisonville, VA & 01660500 & & & 1997-2001 & 12.7 \\
\hline \multicolumn{6}{|l|}{ Rappahannock River } \\
\hline Hazel River at Rixeyville, VA & 01663500 & 1953-1955 & USGS daily & & 287 \\
\hline Rappahannock River at Remington, VA & 01664000 & $1953-1993$ & USGS daily & & 620 \\
\hline Rapidan River near Culpeper, VA & 01667500 & $1952-1965$ & USGS daily & & 472 \\
\hline Rappahannock River near Fredericksburg, VA & 01668000 & 1989-2001 & RIM & & 1,596 \\
\hline \multicolumn{6}{|l|}{ York River } \\
\hline Pamunkey River near Hanover, VA & 01673000 & $\begin{array}{l}\text { 1976-1980, 1991- } \\
2001\end{array}$ & Estimator/RIM & 1985-2001 & 1,081 \\
\hline Mattaponi River near Beulahville, VA & 01674500 & 1991-2001 & RIM & $\begin{array}{l}1985-1988 \\
1989-2001\end{array}$ & 601 \\
\hline \multicolumn{6}{|l|}{ James River } \\
\hline James River at Buchanan, VA & 02019500 & $1952-1956$ & USGS daily & & 2,075 \\
\hline James River at Scottsville, VA & 02029000 & 1952-1956 & USGS daily & & 4,584 \\
\hline James River at Cartersville, VA & 02035000 & $\begin{array}{l}\text { 1974-1983, 1987- } \\
2001\end{array}$ & Estimator/RIM & & 6,259 \\
\hline Appomattox River at Matoaca, VA & 02041650 & 1990-2001 & RIM & & 1,340 \\
\hline
\end{tabular}

1 Discharge is measured at Potomac River near Washington D.C., Little Falls Pumping Station (01646500), 1.2 miles upstream of Chain Bridge. 
calendar year to September 30 of the current calendar year. The methods of suspended-sediment sampling and dailyload computation may have differed for each station, including frequency of suspended-sediment sampling, instruments used to collect suspended sediment, and methods used to compute suspended-sediment load. The last active dailyload sediment station ceased operation in 1999 (Cedar Run at Route 646 near Aden, Virginia). Instantaneous suspended-sediment data were collected at the daily-load stations. Instantaneous suspended-sediment data were also collected as part of water-quality sampling programs, such as the National Stream Quality Accounting Network

(NASQAN), but suspended-sediment daily loads were never computed. Langland and others (1995) used a load-estimator model (ESTIMATOR) to compute monthly and annual suspended-sediment loads from the instantaneous suspended-sediment data for 127 sites in the Chesapeake Bay Watershed where daily loads had not previously been computed. Beginning in 1985, the USGS began estimating monthly and annual suspended-sediment loads using the ESTIMATOR model for nine major tributaries to the Chesapeake Bay, referred to as the River Input Monitoring (RIM) stations (Darrell and others, 1999).

\section{Purpose and Scope}

The USGS is engaged in several studies to identify sediment sources and sediment transport to the Chesapeake Bay. The purpose of this report is to provide a comprehensive summary of USGS data on suspended-sediment loads and concentrations from 1952 through 2002 for selected stream-gaging stations draining the nontidal parts of the Chesapeake Bay Watershed, and to identify areas in the Chesapeake Bay Watershed with high suspended-sediment loads, yields, and concentrations. The sediment data described in this report will provide useful information to Chesapeake Bay water-resources managers for identifying major source areas of sediment by drainage basin.

\section{Previous Studies}

Several studies relating sediment yield to land use have been conducted in the Chesapeake Bay Watershed (Guy and Ferguson, 1962; Jones, 1966; Williams and Reed, 1972). To assess possible sediment sources on a regional scale, Williams and Reed (1972) investigated sediment yields at 33 USGS stream-gaging stations in the Susquehanna River Basin, using data from 1962 to 1967. For basins draining more than $100 \mathrm{mi}^{2}$, sediment yield was related to mining, geologic history, and physiographic region (Williams and Reed, 1972). The highest sediment yields (greater than 200 tons $/ \mathrm{mi}^{2}$, or tons per square mile) occurred in the glaciated portions of the Appalachian Low Plateau Province, coal-mining areas of the Valley and Ridge Province, and the Piedmont Province. The lowest sediment yields were found in subbasins of the Valley and Ridge Province draining more than 25 percent limestone. Internal drainage, presumably of karst topography, was cited as the cause for the low sediment yields in the limestone terrain.
Jones (1966) evaluated sediment data from a pairedbasin study, Corey Creek (12.2 mi $\left.{ }^{2}\right)$ and Elk Run $\left(10.2 \mathrm{mi}^{2}\right)$ in northern Pennsylvania, to determine the effects of land treatment on sediment yields. The Corey Creek Basin was chosen for extensive conservation treatments. Elk Run, a similar basin where only minor conservation treatments were applied, served as an external control to evaluate possible hydrologic changes resulting from treatments in Corey Creek. Sediment loads over the study period (1954 through 1960) decreased 11 percent in Corey Creek relative to Elk Run. Conservation practices such as converting land cover from cropland to grass were cited as the main cause for the decrease in sediment loads in Corey Creek. Extensive water-diversion terraces, installed in 19 percent of the Corey Creek Basin to reduce runoff and sediment transport, had little effect on reducing sediment loads and caused a sharp rise in sediment yields during construction (Jones, 1966).

Several other studies provide estimates of sediment yields from land disturbance in the Chesapeake Bay Watershed region. Guy and Ferguson (1962) reported yields of 25,000 to 50,000 tons $/ \mathrm{mi}^{2}$ resulting from construction work around Washington, D.C. Wolman (1967) also reported sediment yields exceeding 100,000 tons $/ \mathrm{mi}^{2}$ from construction activities in the Washington, D.C. area. Roberts and Pierce (1976) suggested that the Patuxent River more than doubled its sediment yield after urbanization (408 to 983 tons $/ \mathrm{mi}^{2}$ ).

Brown and others (1988) used ${ }^{10} \mathrm{Be}$ (an isotope of beryllium) to estimate soil erosion in 48 basins of the eastern United States, including 10 basins that drain to the Chesapeake Bay. For the entire data set, the highest rates of erosion were observed in the streams in the Piedmont Physiographic Province and the lowest rates were observed in streams in the Coastal Plain Province. The difference in erosion rates between Piedmont and Coastal Plain streams was attributed to differences in land use and stream gradient. Farming, which has occurred in the Piedmont Province for two centuries, has disturbed the topsoil and has led to high rates of soil erosion, as well as sediment with higher concentrations of ${ }^{10} \mathrm{Be}$. Compared to Coastal Plain streams, the higher slopes in Piedmont watersheds have also contributed to higher erosion rates. Annual pre-colonization sediment yield for the Piedmont was estimated to be 34.3 tons $/ \mathrm{mi}^{2}$, a value that is similar to modern undisturbed basin sediment yields (Brown and others, 1988).

Langland and others (1995) used suspended-sediment data collected from 127 nontidal sites draining the Chesapeake Bay Watershed to examine the influence of land cover on total suspended solids (TSS) and suspended-sediment concentrations. They found that the largest median concentration of suspended sediment was in the upper Potomac River Basin, and that the highest concentrations of suspended sediment were in the Susquehanna River Basin. Correlations of annual sediment yields to land use, computed with a log-linear multiple regression model, indicated that basins with the highest percentage of agriculture had the 
highest sediment yields. Basins with the highest percentage of forest cover had the lowest sediment yields.

Suspended-sediment concentrations analyzed for four of the RIM stations from 1985 through 1996 (Susquehanna, Potomac, Patuxent, and Choptank Rivers) (Darrell and others, 1999) showed the Patuxent River had the highest median suspended-sediment concentrations $(45 \mathrm{mg} / \mathrm{L}$, or milligrams per liter). The Potomac River had the highest median-annual sediment yield (175 tons $/ \mathrm{mi}^{2}$ ) (Darrell and others, 1999).

\section{Methods of Study}

Two types of suspended-sediment data were analyzed in this report, suspended-sediment loads and instantaneous suspended-sediment concentrations. The data were acquired from a variety of sources. Suspended-sediment load data were obtained from: (1) daily sediment stations operating in the Chesapeake Bay Watershed (USGS Water Resources Data Reports for Maryland (1962-93), New York (1975-80), Pennsylvania (1952-86), and Virginia (1952-99)), (2) ESTIMATOR model runs (Langland and others, 1995), (3) RIM stations (Belval and Sprague, 1999), (4) the USGS National Water Information System (NWIS) data base, and

(5) the USGS web site for suspended-sediment data (U.S. Geological Survey, 2003). Instantaneous measurements of suspended-sediment concentration and discharge were compiled from NWIS.

In this report, the term "watershed" is used to describe the entire area that drains to the Chesapeake Bay. The term "basin" is used to describe drainages within the Chesapeake Bay Watershed that are associated with major rivers: the Choptank, James, Patuxent, Potomac, Rappahannock, Susquehanna, and York Rivers. Drainage areas within basins are referred to as "subbasins." Tables and plots of the suspended-sediment data are presented according to major drainage basin.

Suspended-sediment loads obtained from USGS daily suspended-sediment load stations and the ESTIMATOR model results were summed by WY and averaged to calculate an average annual suspended-sediment load for each station. All annual data presented in this report are based on WY, rather than calendar year, and only years with $12 \mathrm{com}-$ plete months of data were used. Only stations with at least 3 complete WYs of record were included in this study, and the years did not have to be consecutive. If for a given WY a station had loads reported by both a daily-load station and from the ESTIMATOR model, only the data from the dailyload station were used. Suspended-sediment load data were normalized by drainage area to calculate sediment yield (tons $/ \mathrm{mi}^{2}$ ). Guy (1964) determined that the dischargeweighted concentration of sediment for a storm event was a better dependent variable than sediment load for factors that affect storm period sediment transport, so WY suspendedsediment loads also were normalized by WY runoff to calculate a discharge-weighted sediment concentration
(mg/L). WY runoff was obtained from NWIS or USGS Water Resources Data Reports for Maryland, New York, Pennsylvania, and Virginia (1952-99).

Suspended-sediment load, yield, and concentration data were analyzed for two periods-1984 and earlier, and 1985 and later. In 1985, the Chesapeake Bay Program began recommending sediment and nutrient regulation, so 1985 represents an important break in the data.

To determine if average WY suspended-sediment loads, yields, and discharge-weighted sediment concentrations at each station for their respective collection periods were representative of longer-term flow conditions, the average WY mean-daily discharge was calculated for the sedimentcollection period and compared to the mean-daily discharge for the entire period of streamflow record. Information on historical streamflow records was obtained from NWIS.

The Chesapeake Bay River Input Monitoring (RIM) program was established in the mid-1980s to quantify loads and long-term trends in suspended sediment entering the tidal part of the Chesapeake Bay Basin from its nine major tributaries (Appomattox, Choptank, James, Mattaponi, Pamunkey, Patuxent, Potomac, Rappahannock, and Susquehanna) (Darrell and others, 1999). The RIM stations are near the "Fall Line," a natural boundary between the Piedmont and Coastal Plain Physiographic Provinces in the eastern United States, where there is a relatively large change in elevation (fig. 1). This line roughly represents the boundary between the tidal and nontidal parts of each river. The RIM stations monitor approximately 78 percent of the streamflow entering Chesapeake Bay from the nontidal part of its watershed (Darrell and others, 1999). The RIM sediment data for the period 1985 through 2001 were examined as part of this report.

Suspended-sediment concentrations in tributaries to the Chesapeake Bay were determined from samples collected using methods described by Edwards and Glysson (1988). In most cases, this involved the use of depth-integrating samplers deployed by either the Equal-Width Increment or Equal-Discharge Increment techniques, or with automatic samplers (Edwards and Glysson, 1988). Analyses of suspended-sediment concentrations and particle-size distributions were performed by methods described by the American Society for Testing and Materials (ASTM, 1999), Knott and others (1992), and Guy (1969). Porterfield (1972) and Koltun and others (1994) describe the methodology that was used for computing daily suspended-sediment loads. Daily suspended-sediment loads obtained for this report were generally computed by the subdivision technique (Porterfield, 1972) but other methods, such as the sediment rating curve-flow duration method (Porterfield, 1972), may also have been used. In the subdivision method, individual samples of suspended-sediment concentrations are plotted and a continuous trace of suspended-sediment concentration is drawn between concentration values.

The relation between instantaneous water discharge and suspended-sediment concentration is referred to as a sediment-transport curve (Glysson, 1987). In the computation of 
suspended-sediment loads, sediment-transport curves were used to estimate suspended-sediment concentrations for periods when samples were not sufficient to define concentration by time. During periods of low flow, the average daily suspended-sediment concentration $(\mathrm{mg} / \mathrm{L})$ is multiplied by the average discharge ( $\mathrm{ft}^{3} / \mathrm{s}$, or cubic feet per second) and a coefficient (0.0027) to compute sediment in tons per day. During periods of higher flows or rapidly varying flows, the suspended-sediment concentrations and water discharge are divided into smaller periods. The mid-interval or mean interval of suspended sediment and discharge for each period are multiplied together and by 0.0027 to compute a sediment load for each period. Loads computed for each period are summed to obtain a daily load. Porterfield (1972) states that the visual procedure to construct continuous temporal concentration curves is the most common and accurate method when supplemented with sediment-transport curves.

The ESTIMATOR model uses a linear regression method, whereby the line of best fit developed from the relation of mean-daily discharge to suspended sediment or TSS is used to calculate suspended-sediment load (Cohn and others, 1989, 1992). With this method, a curvilinear relation between measurements of stream discharge and suspendedsediment loads is derived on a logarithmic scale. The empirical relation is applied to stream discharges for periods of interest (monthly or annual). Langland and others (1995) used the ESTIMATOR model to quantify monthly and annual suspended-sediment loads for 127 sites in the Chesapeake Bay Watershed. Monthly and annual loads for the RIM stations also were calculated with the ESTIMATOR model.

Average annual suspended-sediment loads, sediment yields, and discharge-weighted sediment concentrations in this report are displayed spatially for two time periods1984 and earlier, and from 1985 through 2001, using a geographical information system (GIS). The RIM station data, which are representative of a major portion of the Chesapeake Bay Watershed, are shown separately to illustrate sediment transport at the major watershed scale. Data from the RIM network were used to calculate sediment loads starting in 1985; therefore, only the period from 1985 through 2001 is displayed.

In this report, instantaneous measurements of suspendedsediment concentrations were analyzed and interpreted through examination of the distribution (percentiles) of suspended-sediment concentrations and analysis of sedimenttransport curves. Only sediment data and discharge data from 1985-2002 were used to compute percentiles and sediment-transport curves. In addition, only stations with a minimum of 3 complete years of data and 10 or more suspendedsediment samples in a given year were used. Percentiles $\left(10^{\text {th }}, 50^{\text {th }}\right.$, and $\left.90^{\text {th }}\right)$ for instantaneous measurements of suspended sediment were determined using standard statistical software (SAS Institute Inc., Version 6, 1994).
To determine whether the suspended-sediment samples were biased towards either a low- or high-flow condition, mean-daily discharge values measured on days when suspended-sediment samples were collected were compared to mean-daily discharge values for all the years meeting the criteria listed above that contained suspended-sediment data. Mean-daily discharges were retrieved from the NWIS data base. A two-sided, Mann-Whitney-Wilcoxon test (Helsel and Hirsch, 1992) was used to determine if the ranked meandaily discharges differed in the two populations - the sample population of mean-daily discharges on days when suspended-sediment samples were collected and the population of mean-daily discharge values for all the years that contained sediment data. The null hypothesis that the distribution of data of the two populations was similar was rejected at the 95-percent confidence level (alpha $=0.05$ ).

Sediment-transport curves have been used to determine impaired streams and undisturbed or reference streams (Simon and others, 2001; Troendle and others, 2002). Troendle and others (2002) created pooled dimensionless sediment-transport curves for 160 reference sites in the western United States. A dimensionless transport curve is created by normalizing each discharge value by the discharge at bankfull flow and each suspended-sediment value by the suspended-sediment concentration at bankfull flow. Bankfull flow is the discharge that occurs every 1.5 years. The dimensionless transport curve for Coon Creek, Wyoming, a timber-harvested basin, was shown to depart significantly from the reference transport curve, and was considered impaired.

Sediment-transport curves were generated for all stations in this study with at least 3 complete years of data and at least 10 suspended-sediment samples in a given year. The sediment-transport curves are shown with a line of best fit, determined using a standard computer-graphing package (SIGMAPLOT, SPSS, Inc., Version 7.0, 2001) to indicate the general trend in the data. It was not determined whether the slope of the line of best fit was statistically different from zero.

When plotted together, sediment-transport curves for different rivers may indicate rivers that have higher suspendedsediment concentrations at a given discharge. Because drainage area is a controlling factor in runoff and sediment transport, in order to compare sediment-transport curves between rivers with different contributing areas, sedimenttransport curves were separated by drainage-area classes. A metric scale provided order-of-magnitude divisions to classify drainage areas. Based on the number of sites and ensuring that no class had fewer than four sites, the following classes were used: 


$\begin{array}{rlrl}\text { Class A } & >25,000-70,200 \mathrm{~km}^{2} \\ \text { (square kilometers) } & & \begin{array}{c}\left(>9,650-27,100 \mathrm{mi}^{2} ;\right. \\ \text { square miles) }\end{array} \\ \text { Class B }>2,500-25,000 \mathrm{~km}^{2} & \left(>965-9,650 \mathrm{mi}^{2}\right) \\ \text { Class C }>1,000-2,500 \mathrm{~km}^{2} & \left(>386-965 \mathrm{mi}^{2}\right) \\ \text { Class D }>500-1,000 \mathrm{~km}^{2} & \left(>193-386 \mathrm{mi}^{2}\right) \\ \text { Class E }>250-500 \mathrm{~km}^{2} & \left(>96.5-193 \mathrm{mi}^{2}\right) \\ \text { Class F }>100-250 \mathrm{~km}^{2} & \left(>38.6-96.5 \mathrm{mi}^{2}\right) \\ \text { Class G }>20-100 \mathrm{~km}^{2} & \left(>7.70-38.6 \mathrm{mi}^{2}\right) \\ \text { Class H }>0.93-20 \mathrm{~km}^{2} & \left(0.36-7.70 \mathrm{mi}^{2}\right)\end{array}$

There is still a broad range of drainage areas in each class. To minimize any influence of area, discharge was normalized by drainage area.

\section{Limitations of Data and Methods of Analysis}

Nine of the stations that operated from 1973 through 1993 have suspended-sediment loads computed as daily loads and suspended-sediment loads computed by the ESTIMATOR method, for selected years, constituting a total of 36 years of comparable data. The individual records for each station were not obtained, but the daily suspended-sediment loads were most likely computed by the subdivision method; however, at times the flow duration method may have been used. Differences in load computations may occur between the subdivision method and the ESTIMATOR method. Walling (1977) reported load overestimates of 280 percent when using a linear-regression method compared to the subdivision method. In contrast to these findings, Horowitz (2003) reported that the linear (or polynomial) regression method tends to under-predict high suspended-sediment concentrations, but can generate annual suspended-sediment load estimates within 20 percent. In this analysis, a comparison using both methods shows that ESTIMATOR has a tendency to calculate higher suspended-sediment loads than the method used for the dailyload computations, which were most likely calculated using the subdivision method (fig. 2). Figure 2 shows that the difference in suspended-sediment loads computed by ESTIMATOR and daily suspended-sediment loads is greater at the higher suspended-sediment loads.

Sediment-load computations at the four Virginia RIM stations (Pamunkey River near Hanover, Virginia, station 01673000; Mattaponi River at Beulahville, Virginia, station 01674500; James River at Cartersville, Virginia, station 02035000; and Appomattox River at Matoaca, Virginia, station 02041650) (fig. 1, table 1) were based on TSS data. Gray and others (2000) showed that the TSS method tends to under-predict concentrations when the sand content of the sample exceeds about one-quarter of the sediment by weight. Therefore, load estimations based on TSS at the Virginia RIM stations could be underestimated.

Another major limitation is sample-collection methodology. At times, samplers other than isokinetic samplers, such as point samplers and bottles, may have been used to collect

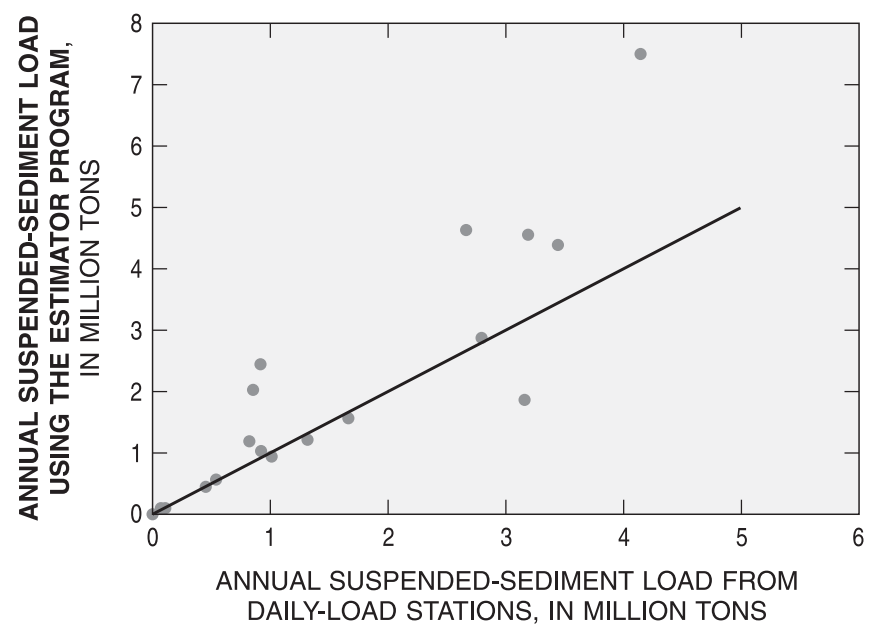

Figure 2. Average annual water year suspended-sediment load computed at daily-load stations compared with loads computed with the Estimator program for water years 1973 through 1993.

suspended sediment. Although samples should be collected at a minimum of 10 verticals in a cross section (Edwards and Glysson, 1988), sometimes a single vertical may have been used. Typically, several bottles are collected in association with a cross-sectional sample. Each bottle is sent to the laboratory for analysis of suspended-sediment concentration and composited to obtain a value. Bottles have sometimes been composited in the field with equipment such as a churn or cone splitter to obtain a single concentration. Because sample-collection methodology varied over time and space, it is difficult to quantify the errors associated with using methods other than those recommended by Edwards and Glysson (1988).

Sampling frequency is another important factor that can affect the accuracy of the annual suspended-sediment load computation. Because most rivers transport 80 to 90 percent of their annual load during storm runoff events (Meade and others, 1990), sediment sampling at high flows is favorable for a good sediment record. Continuous suspended-sediment sampling during the storm runoff hydrograph is also favorable for producing an accurate continuous sediment trace. The relation of suspended-sediment samples to high flows was not examined for the suspended-sediment load data. 


\section{Summary of Sediment Loads, Yields, and Discharge-Weighted Sediment Concentrations}

Sixty-five stations with at least 3 complete years of record were selected for analysis of suspended-sediment load data (figs. 1 and 3). The greatest number of stations functioning concurrently (27) were in operation from 1989-91 (fig. 3). The station with the longest record is the Rappahannock River at Remington, Virginia (station 01664000), with 40 years of data (fig. 3). The distribution of drainage areas for all sediment stations operating from 1952 through $2001(n=65)$ indicates that the most sediment stations operating at any time were in basins draining between 100 and $500 \mathrm{mi}^{2}$, whereas the least number of sediment stations operating at any time were in basins draining 50 and $100 \mathrm{mi}^{2}$ (fig 4). Suspended-sediment loads are highly correlated to drainage area and to average annual mean-daily discharge for the sediment collection period (figs. 5a-b). Drainage area shows a weak, inverse relation to sediment yield and to discharge-weighted sediment concentration (figs. 5c-d). Schumm (1977) and Walling (1983) described decreasing sediment yield with increasing basin area as more sites in a basin become available for sediment storage.

\section{River Input Monitoring Station Data, 1985-2001}

The RIM stations provide data on suspended-sediment loads delivered to the tidal parts of the Chesapeake Bay Watershed. The RIM station data for 1985 through 2001 show that the Potomac and Susquehanna Rivers had the two highest suspended-sediment loads (fig. 6a, table 2). When normalized by either drainage area or average annual runoff, the highest average annual sediment yields and average annual discharge-weighted sediment concentrations were in the Rappahannock and Potomac Rivers (figs. 6 b-c, and table 2). Although the Susquehanna River at Conowingo, Maryland (station 01578310) drains a large area (27,100 $\mathrm{mi}^{2}$ ), the Susquehanna River at Conowingo, Maryland, has three large dams upstream that are trapping about two-thirds of the suspended-sediment load (Langland and Hainly, 1997), thereby lowering the river's sediment yields. The Choptank, Mattaponi, and Appomattox Rivers had the lowest average annual suspended-sediment loads, sediment yields, and discharge-weighted sediment concentrations (fig. 6c, table 2).

\section{Suspended-Sediment Data, 1952 through 1984}

Forty-three stations operating from 1952 through 1984 had suspended-sediment load data with 3 or more years of record (figs. $7 \mathrm{a}-\mathrm{c}$, table 3 ). Almost one-half of the stations (20) had average annual mean-daily discharge during the study period that was within 10 percent of the average annual mean-daily discharge for the entire period of record. Sixteen stations had average annual mean-daily discharges greater than 10 percent (10.5 to 27.3 percent) of the average WY mean-daily discharges for their respective periods of record. This could indicate that sediment loads for these sta- tions could be higher under average flow conditions. Seven stations had average annual mean-daily discharge that was less than 10 percent (-11 to -23 percent) of the average annual mean-daily discharge for the period of record. At these stations, sediment loads could be lower than under average flow conditions. In summary, about one-half (46.5 percent) of the sediment data was not biased toward lower or higher flow conditions. About 37 percent of the sediment data were collected under flow conditions that were greater than 10 percent of the average mean-daily flow, and 16.3 percent of the sediment data were collected under flow conditions that were less than 10 percent of the average mean-daily flow.

For 1952 through 1984, the highest average annual suspended-sediment load was at the Potomac River at Chain Bridge, Washington, D.C. (2.92 x $10^{6}$ tons/yr, or tons per year) (table 4). The next three highest average annual suspended-sediment loads were at stations on the Susquehanna River (Susquehanna River at Harrisburg, Pennsylvania, $2.88 \times 10^{6}$ tons/yr; Susquehanna River at Sunbury, Pennsylvania, $2.19 \times 10^{6}$ tons/yr; and Susquehanna River at Conowingo, Maryland, $1.64 \times 10^{6}$ tons/yr) (fig. 7a, tables 3-4). Suspended-sediment load is highly correlated to drainage area. The stations with the highest suspended-sediment loads also drain the largest area (table 3).

Normalizing average annual suspended-sediment loads by drainage area and runoff showed that streams in the Washington, D.C. area had the three highest sediment yields and discharge-weighted sediment concentrations (Snakeden Branch at Reston, Virginia-1,140 tons $/ \mathrm{mi}^{2} / \mathrm{yr}$, or tons per square mile per year, $653 \mathrm{mg} / \mathrm{L}$; Smilax Branch at Reston, Virginia-989 tons/ $\mathrm{mi}^{2} / \mathrm{yr}, 585 \mathrm{mg} / \mathrm{L}$; and Northwest Branch Anacostia River near Colesville, Maryland-702 tons $/ \mathrm{mi}^{2} / \mathrm{yr}$, $660 \mathrm{mg} / \mathrm{L}$ ) (figs. 7b-c; tables 3-4). The high sediment yields and sediment concentrations in the Washington, D.C. area could reflect construction and urbanization during the study period (Guy and Ferguson, 1962; Wolman, 1967).

The lowest average annual sediment yields and discharge-weighted sediment concentrations for stations with data collected between 1952-1984 were from Young Womans Creek in Pennsylvania (7.6 tons $/ \mathrm{mi}^{2} / \mathrm{yr}$, $4.3 \mathrm{mg} / \mathrm{L}$ ), the Choptank River on Maryland's Eastern Shore (21.9 tons $/ \mathrm{mi}^{2} / \mathrm{yr}, 16.0 \mathrm{mg} / \mathrm{L}$ ), and the Pamunkey River in Virginia (22.3 tons $/ \mathrm{mi}^{2} / \mathrm{yr}, 20.2 \mathrm{mg} / \mathrm{L}$ ) (figs. $3 \mathrm{~b}-\mathrm{c}$, table 3). The Young Womans Creek watershed in Pennsylvania is entirely forested (Hainly and Loper, 1997).

\section{Suspended-Sediment Data, 1985 through 2001}

Thirty-five stations had suspended-sediment load data from 1985 through 2001 with 3 or more years of record (figs. 8 a-c, table 5). Most of the stations (57 percent) had average annual mean-daily discharge for the collection period within plus or minus 10 percent of the average annual mean-daily discharge for the entire period of record. About one-third of the stations (31 percent) had an average annual mean-daily discharge that was 10 to 20 percent (-10 to -20 percent) lower than the mean-daily discharge for the period of record. Only three stations, Monocacy River 
at Bridgeport, Maryland (14.9 percent), Little Conestoga Creek site 3A near Morgantown (10.9 percent), and Conococheague Creek at Fairview, Maryland (48.2 percent), had average annual mean-daily discharges that were higher than 10 percent of the mean-daily discharge for the period of record. For these two stations, suspended-sediment loads may be higher than those measured during average flow conditions.

For the period 1985 through 2001, stations on the Potomac River had the highest and third highest average annual suspended-sediment load (Potomac River at Chain Bridge, Washington, D.C., $1.84 \times 10^{6}$ tons/yr, and Potomac River at Point of Rocks, Maryland, $1.13 \times 10^{6}$ tons/yr, respectively) (fig. 8a, tables 5-6). The Potomac River at Chain Bridge is the RIM station for the Potomac River Basin. The second highest average annual suspended-sediment load was at the Susquehanna River at
Marietta, Pennsylvania ( $1.70 \times 10^{6}$ tons/yr). This site is upstream of major reservoirs that may trap and remove sediment (table 6). When normalized by drainage area and runoff, four of the five highest average annual sediment yields and discharge-weighted sediment concentrations are for stations that drain to the Susquehanna River in Pennsylvania (Little Conestoga Creek near Churchtown, Pennsylvania; Little Conestoga Creek site 3 near Morgantown, Pennsylvania; Mill Creek at Eshelman Mill Road near Lyndon, Pennsylvania; and Raystown Branch Juniata River at Saxton, Pennsylvania) (figs. 8a-c, tables 5-6). Three of the four Pennsylvania stations are in the Conestoga River Basin (two stations on Little Conestoga Creek and one on Mill Creek). The Conestoga River Basin drains primarily agricultural land, which may be influencing the high sediment yields and concentrations.

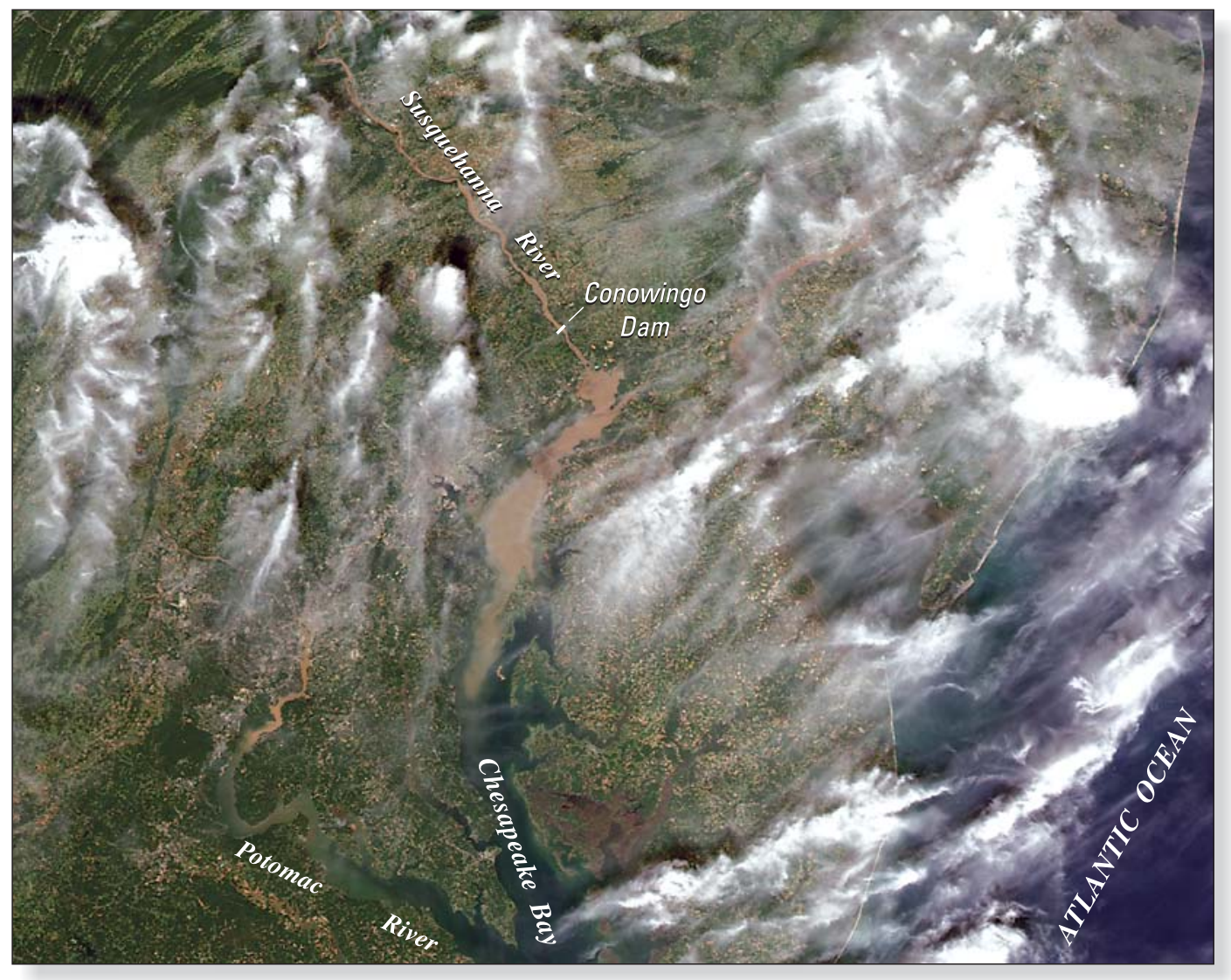

Photograph showing the high suspended-sediment concentrations caused by a large storm, Hurricane Ivan, which affected parts of the Chesapeake Bay Watershed from September 17-18, 2004. (NASA Terra satellite image of the Chesapeake Bay Watershed region taken on September 21, 2004, obtained from NASA Internet site http://earthobservatory.nasa.gov/NaturalHazards/shownh.php3?img_id=12456; accessed October 21, 2004). Note the brownish turbid waters of the Susquehanna and Potomac Rivers, and upper Chesapeake Bay. A sample collected at the Susquehanna River at Conowingo, Maryland on September 20, 2004 at 0900 yielded a suspended-sediment concentration of 3,685 milligrams per liter. 


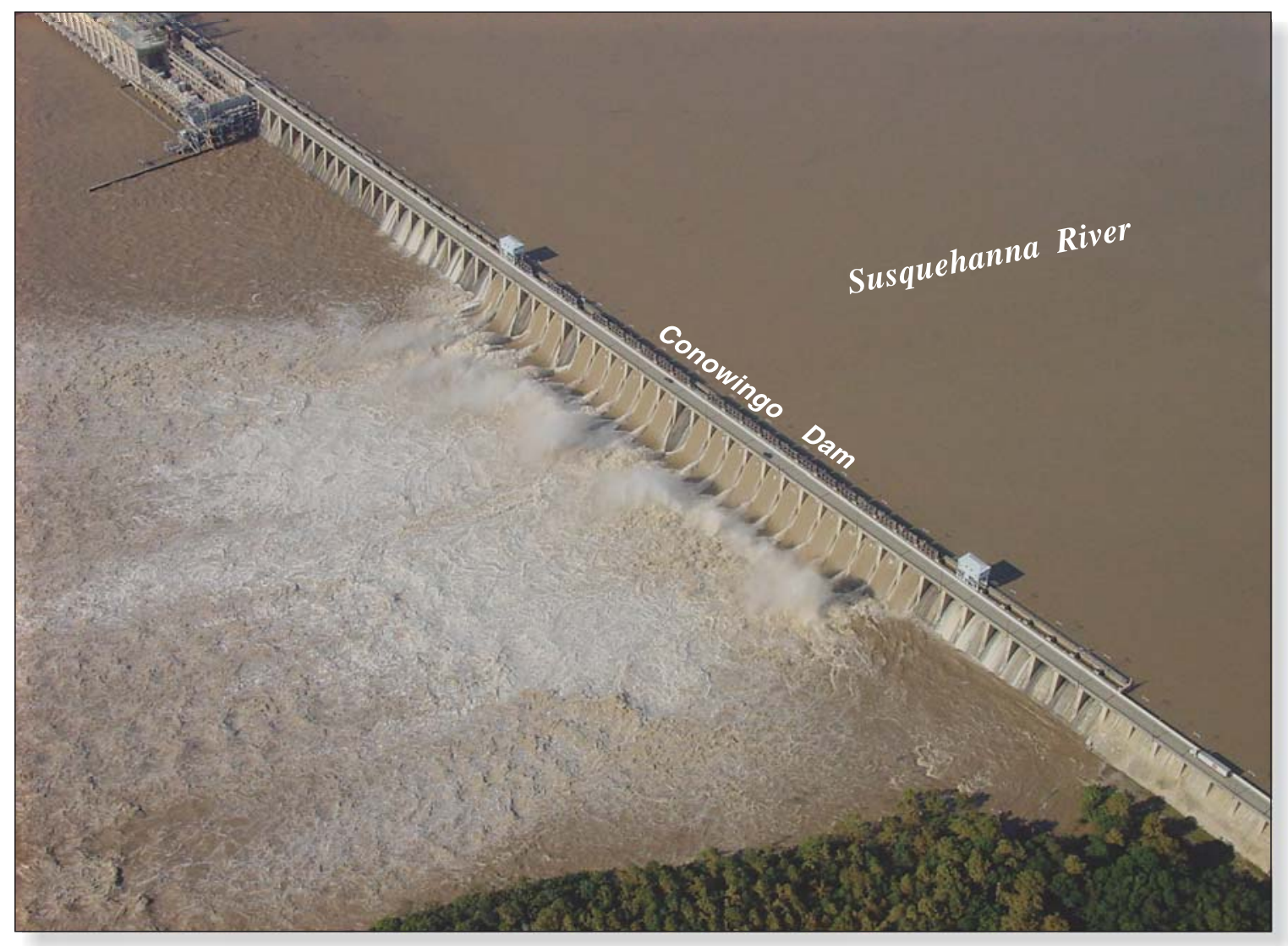

Photograph showing the release of water from the Conowingo Dam on the Susquehanna River in Maryland, September 21, 2004 at 10:00 AM as a result of Hurricane Ivan. When this photograph was taken, discharge at the Susquehanna River near Conowingo, Maryland (USGS station number 01578310 ) was 348,000 cubic feet per second. (Photograph courtesy of Wendy McPherson, USGS). 


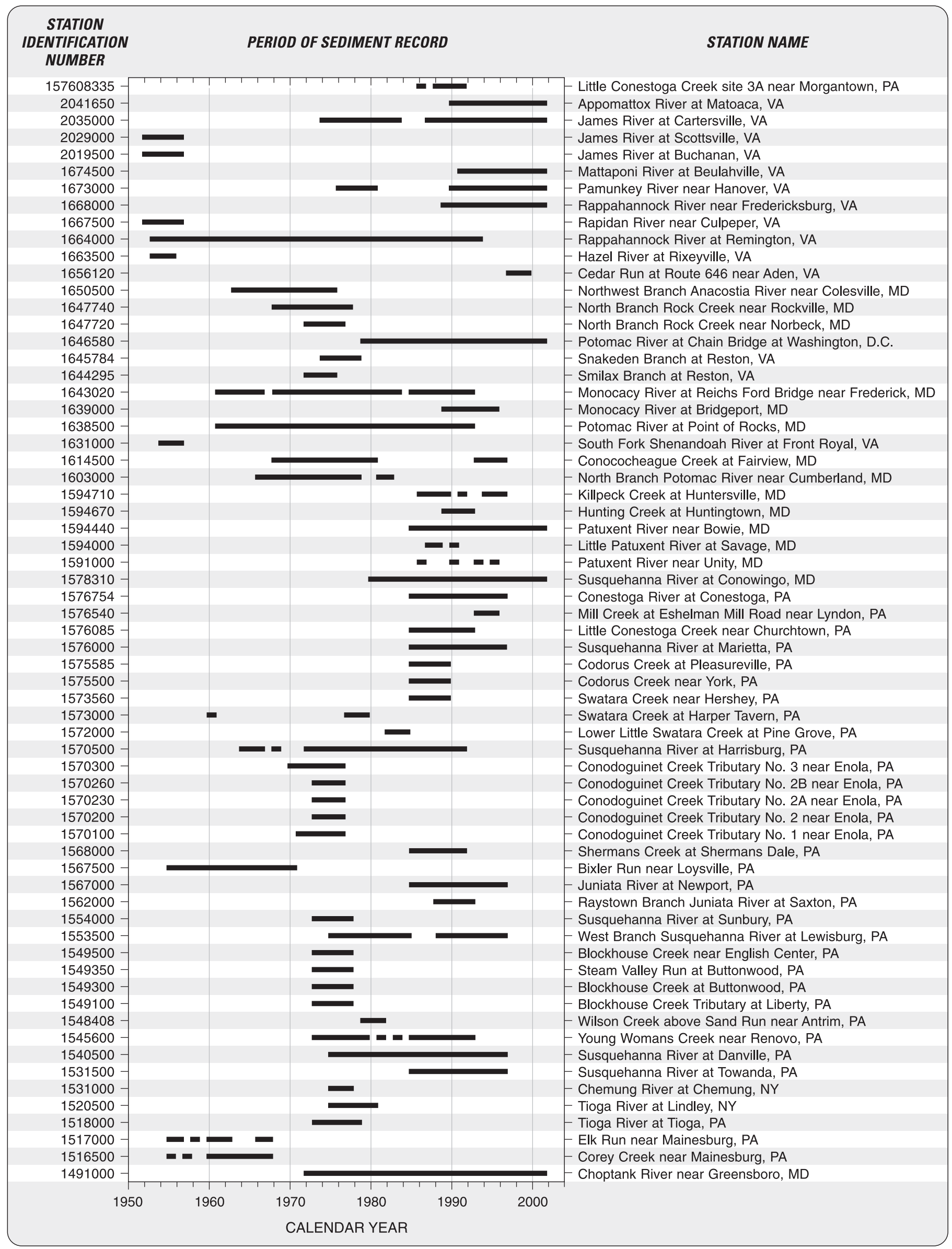

Figure 3. Listing of sediment stations in the Chesapeake Bay Watershed with at least 3 years of record from water years 1952 through 2001. 


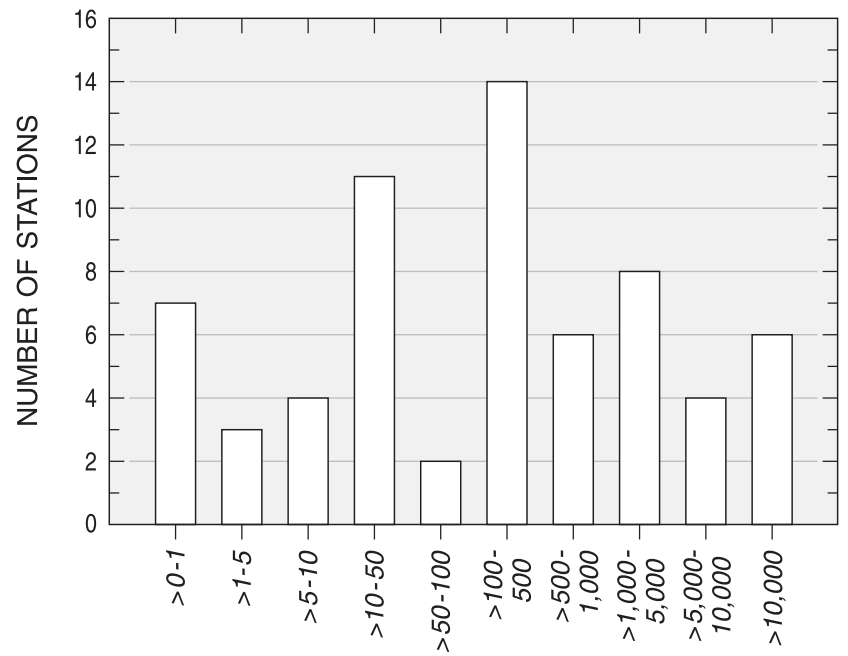

DRAINAGE AREA, IN SQUARE MILES

$(>$, greater than)

Figure 4. Distribution of drainage areas for 65 sediment stations in the Chesapeake Bay Watershed with at least 3 years of sediment record from 1952 through 2001.
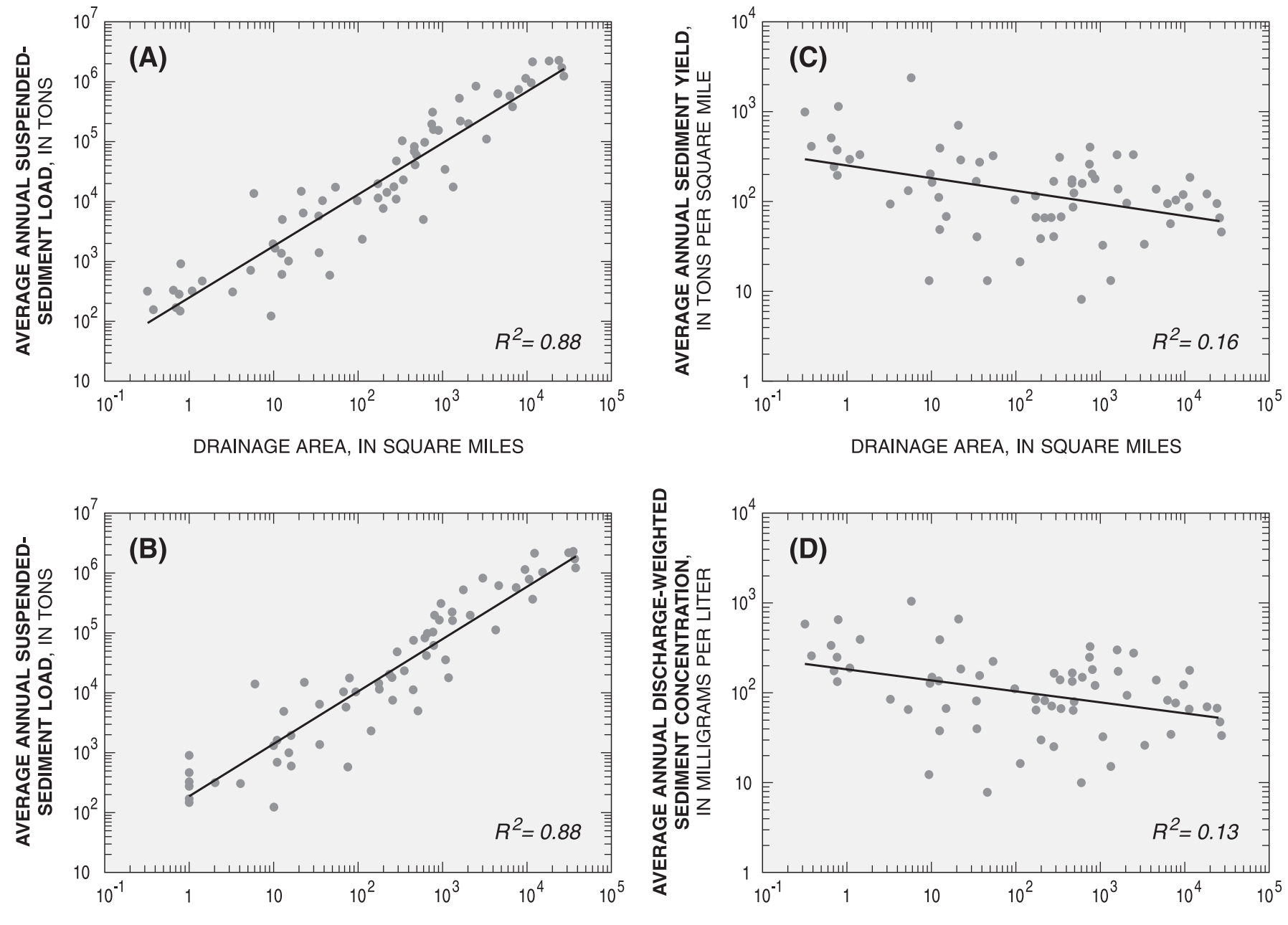

MEAN-DAILY DISCHARGE, IN CUBIC FEET PER SECOND

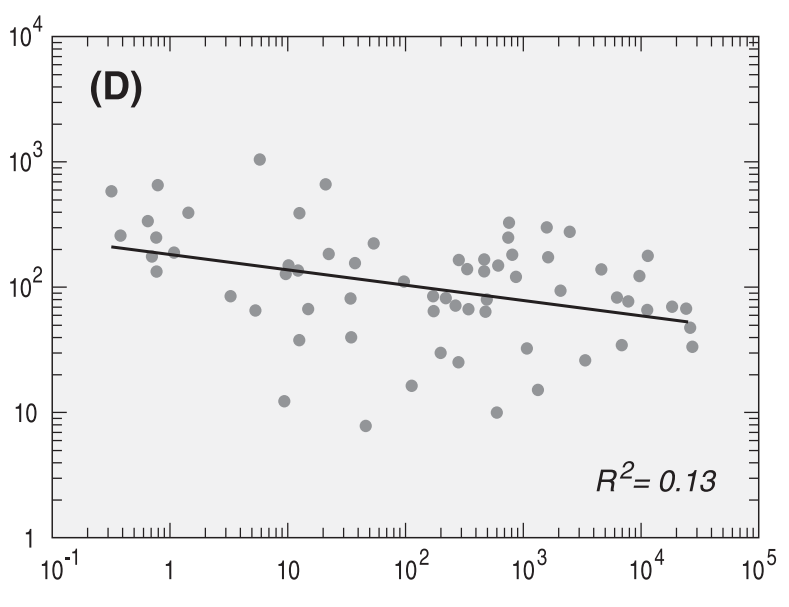

DRAINAGE AREA, IN SQUARE MILES

Figure 5. Relation of (A) average annual suspended-sediment load to drainage area, (B) average annual suspended-sediment load to mean-daily discharge, (C) average annual sediment yield to drainage area, and (D) average annual discharge-weighted sediment concentration to drainage area for 65 sediment stations in the Chesapeake Bay Watershed with at least 3 years of record from 1952 through 2001. 


\title{
EXPLANATION
}

\section{AVERAGE ANNUAL SUSPENDED-SEDIMENT LOAD (1985-2001), in tons per year, and STATION IDENTIFICATION NUMBER}

\author{
01491000 LESS THAN OR EQUAL TO 10,000 \\ $01594440 \bigcirc 10,001-100,000$ \\ $01668000 \bigcirc 100,001-1,000,000$ \\ 01578310 GREATER THAN 1,000,000
}

\section{RIVER INPUT MONITORING (RIM) BASINS}

CHOPTANK RIVER

SUSQUEHANNA RIVER

PATUXENT RIVER

POTOMAC RIVER

RAPPAHANNOCK RIVER

PAMUNKEY RIVER

MATTAPONI RIVER

JAMES RIVER

APPOMATTOX RIVER

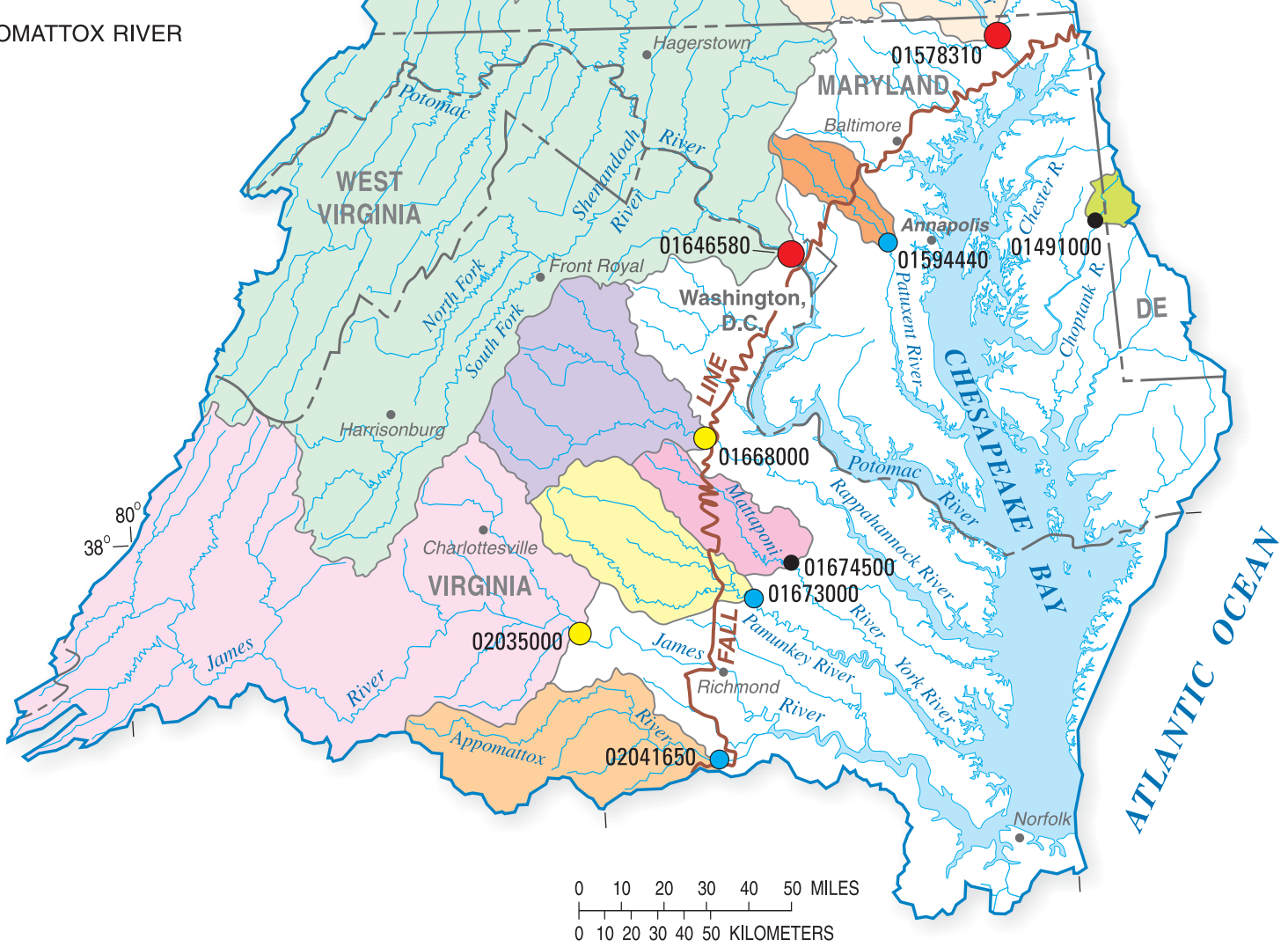

Figure 6a. Average annual suspended-sediment load from 1985 through 2001 for nine River Input Monitoring (RIM) stations in the Chesapeake Bay Watershed. (Refer to table 2 for listing of stations.) 
EXPLANATION

AVERAGE ANNUAL SEDIMENT YIELD

(1985-2001), in tons per square mile, and STATION IDENTIFICATION NUMBER

01578310 LESS THAN OR EQUAL TO 50

$02035000 \bigcirc 51-100$

$01646580 \bigcirc 101-200$

$01668000 \bigcirc$ GREATER THAN 200

RIVER INPUT MONITORING (RIM) BASINS

CHOPTANK RIVER

SUSQUEHANNA RIVER

PATUXENT RIVER

POTOMAC RIVER

RAPPAHANNOCK RIVER

PAMUNKEY RIVER

MATTAPONI RIVER

JAMES RIVER

APPOMATTOX RIVER
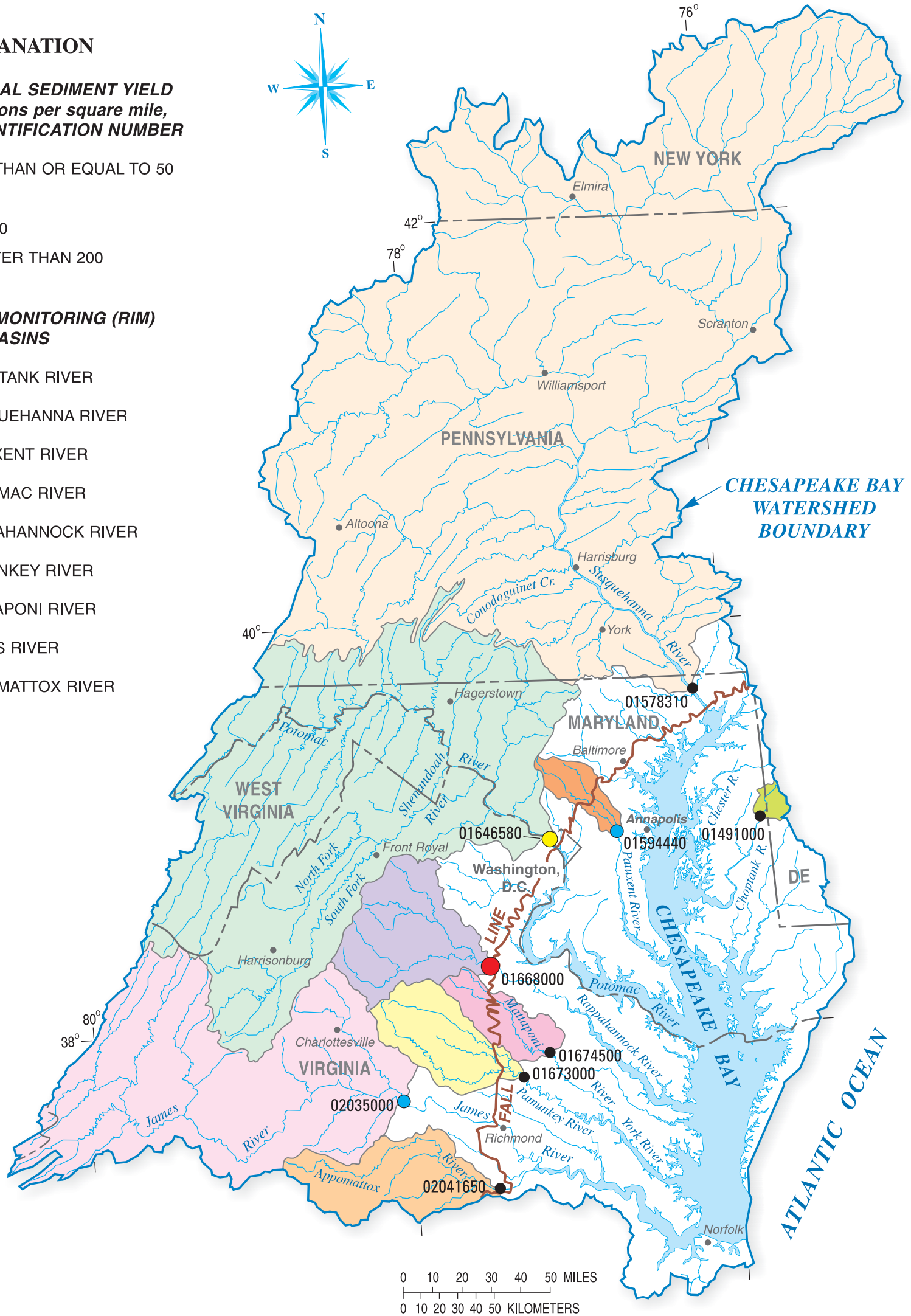

Figure 6b. Average annual sediment yield from 1985 through 2001 for nine River Input Monitoring (RIM) stations in the Chesapeake Bay Watershed. (Refer to table 2 for listing of stations.) 
EXPLANATION

AVERAGE ANNUAL DISCHARGE-WEIGHTED SEDIMENT CONCENTRATION (1985-2001),

in milligrams per liter, and STATION IDENTIFICATION NUMBER

$01578310 \bullet$ LESS THAN OR EQUAL TO 50

$02035000 \bigcirc 51-100$

$01646580 \bigcirc 101-200$

01668000

GREATER THAN 200

RIVER INPUT MONITORING (RIM) BASINS

CHOPTANK RIVER

SUSQUEHANNA RIVER

PATUXENT RIVER

POTOMAC RIVER

RAPPAHANNOCK RIVER

PAMUNKEY RIVER

MATTAPONI RIVER

JAMES RIVER

APPOMATTOX RIVER
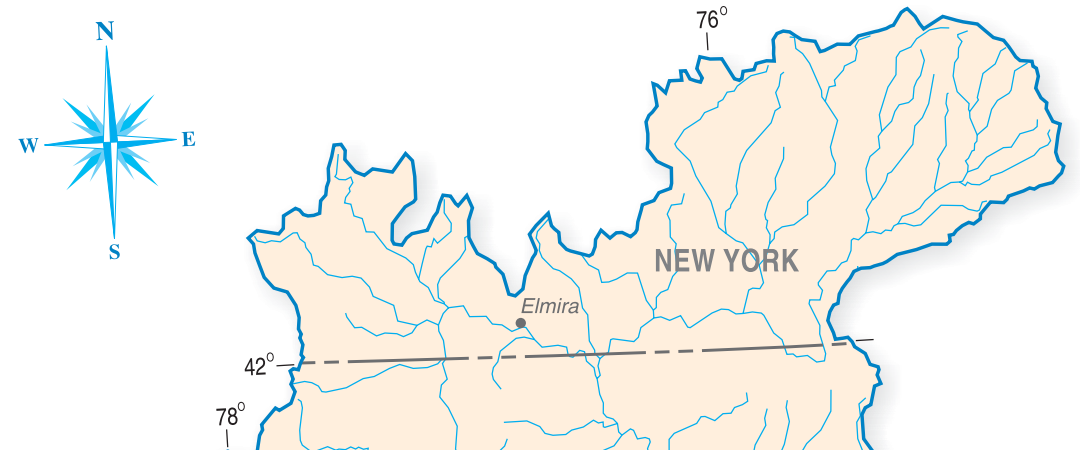
Table 2. Summary of sediment data collected from River Input Monitoring stations, 1985 through 2001

[mg/L, milligrams per liter; Water Year is from October 1 of the previous year to September 30 of the current year.]

\begin{tabular}{|c|c|c|c|c|c|}
\hline $\begin{array}{l}\text { Period } \\
\text { of record } \\
\text { for sediment } \\
\text { collection } \\
\text { (water year) }\end{array}$ & Station name & $\begin{array}{l}\text { Station } \\
\text { identification } \\
\text { number }\end{array}$ & $\begin{array}{l}\text { Drainage } \\
\text { area } \\
\text { (square } \\
\text { miles) }\end{array}$ & $\begin{array}{l}\text { Average } \\
\text { water year } \\
\text { suspended- } \\
\text { sediment } \\
\text { load } \\
\text { (tons) }\end{array}$ & $\begin{array}{l}\text { Average } \\
\text { water year } \\
\text { discharge- } \\
\text { weighted } \\
\text { sediment } \\
\text { concentration } \\
(\mathrm{mg} / \mathrm{L})\end{array}$ \\
\hline 1985-2001 & Choptank River near Greensboro, MD & 01491000 & 113 & 2,310 & 17.3 \\
\hline 1985-2001 & Susquehanna River at Conowingo, MD & 01578310 & 27,100 & $1,110,000$ & 29.9 \\
\hline 1985-2001 & Patuxent River near Bowie, MD & 01594440 & 348 & 23,400 & 67.1 \\
\hline 1985-2001 & Potomac River at Chain Bridge at Washington, D.C. 1 & 01646580 & 11,570 & $1,840,000$ & 157 \\
\hline 1989-2001 & Rappahannock River near Fredericksburg, VA* & 01668000 & 1,596 & 527,000 & 299 \\
\hline 1990-2001 & Pamunkey River near Hanover, VA* & 01673000 & 1,081 & 39,400 & 38.5 \\
\hline 1991-2001 & Mattaponi River at Beulahville, VA* & 01674500 & 601 & 5,030 & 10.0 \\
\hline 1987-2001 & James River at Cartersville, VA* & 02035000 & 6,259 & 608,000 & 83.4 \\
\hline 1990-2001 & Appomattox River at Matoaca, VA* & 02041650 & 1,340 & 17,800 & 15.1 \\
\hline $\begin{array}{l}\text { Period of } \\
\text { record for } \\
\text { discharge } \\
\text { data }\end{array}$ & Station name & $\begin{array}{l}\text { Station } \\
\text { identification } \\
\text { number }\end{array}$ & $\begin{array}{l}\text { Average } \\
\text { water year } \\
\text { sediment } \\
\text { yield, } \\
\text { (tons per } \\
\text { square } \\
\text { mile) }\end{array}$ & 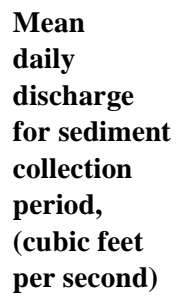 & $\begin{array}{l}\text { Mean } \\
\text { daily } \\
\text { discharge } \\
\text { for period } \\
\text { of record, } \\
\text { (cubic feet } \\
\text { per second) }\end{array}$ \\
\hline 1949-2002 & Choptank River near Greensboro, MD & 01491000 & 20.4 & 135 & 132 \\
\hline 1968-2002 & Susquehanna River at Conowingo, MD & 01578310 & 40.8 & 37,588 & 39,791 \\
\hline 1978-2002 & Patuxent River near Bowie, MD & 01594440 & 67.3 & 355 & 367 \\
\hline $1931-2002$ & Potomac River at Chain Bridge at Washington, D.C. 1 & 01646580 & 159 & 11,938 & 11,256 \\
\hline 1908-2001 & Rappahannock River near Fredericksburg, VA* & 01668000 & 330 & 1,788 & 1,674 \\
\hline $1942-2001$ & Pamunkey River near Hanover, VA* & 01673000 & 36.5 & 1,039 & 1,010 \\
\hline $\begin{array}{l}\text { 1942-1987, } \\
\text { 1990-2001 }\end{array}$ & Mattaponi River at Beulahville, VA* & 01674500 & 8.4 & 512 & 577 \\
\hline $1900-2001$ & James River at Cartersville, VA* & 02035000 & 97.2 & 7,404 & 7,161 \\
\hline 1979-2001 & Appomattox River at Matoaca, VA* & 02041650 & 13.3 & 1,195 & 1,347 \\
\hline
\end{tabular}

* Indicates total suspended solids were collected at the station.

${ }^{1}$ Discharge is measured at Potomac River near Washington D.C., Little Falls Pumping Station (01646500), 1.2 miles upstream of Chain Bridge. 
EXPLANATION

\section{AVERAGE ANNUAL SUSPENDED-SEDIMENT LOAD (1952-1984), in tons per year, and STATION IDENTIFICATION NUMBER}
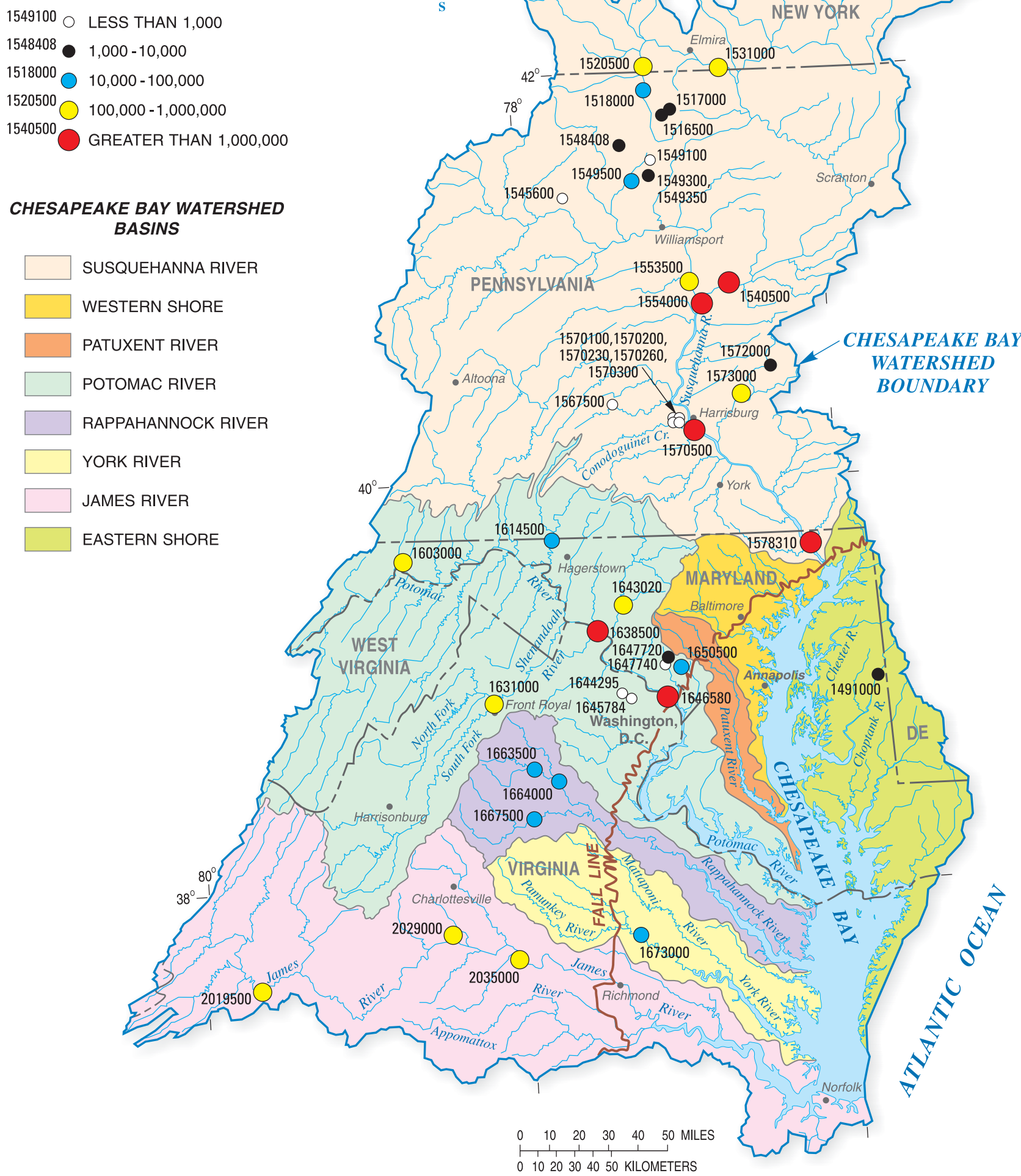

Figure 7a. Average annual suspended-sediment load from 1952 through 1984 for 43 stations in the Chesapeake Bay Watershed with at least 3 years of record. (Refer to table 3 for listing of stations.) 


\section{EXPLANATION}

AVERAGE ANNUAL SEDIMENT YIELD (1952-1984), in tons per square mile, and STATION IDENTIFICATION NUMBER

\author{
$1518000 \bigcirc$ LESS THAN 50 \\ 1553500 50-100 \\ $1517000 \bigcirc 100-200$ \\ $1520500 \bigcirc 200-500$ \\ 1650500 GREATER THAN 500
}

CHESAPEAKE BAY WATERSHED BASINS

SUSQUEHANNA RIVER

WESTERN SHORE

PATUXENT RIVER

POTOMAC RIVER

RAPPAHANNOCK RIVER

YORK RIVER

JAMES RIVER

EASTERN SHORE
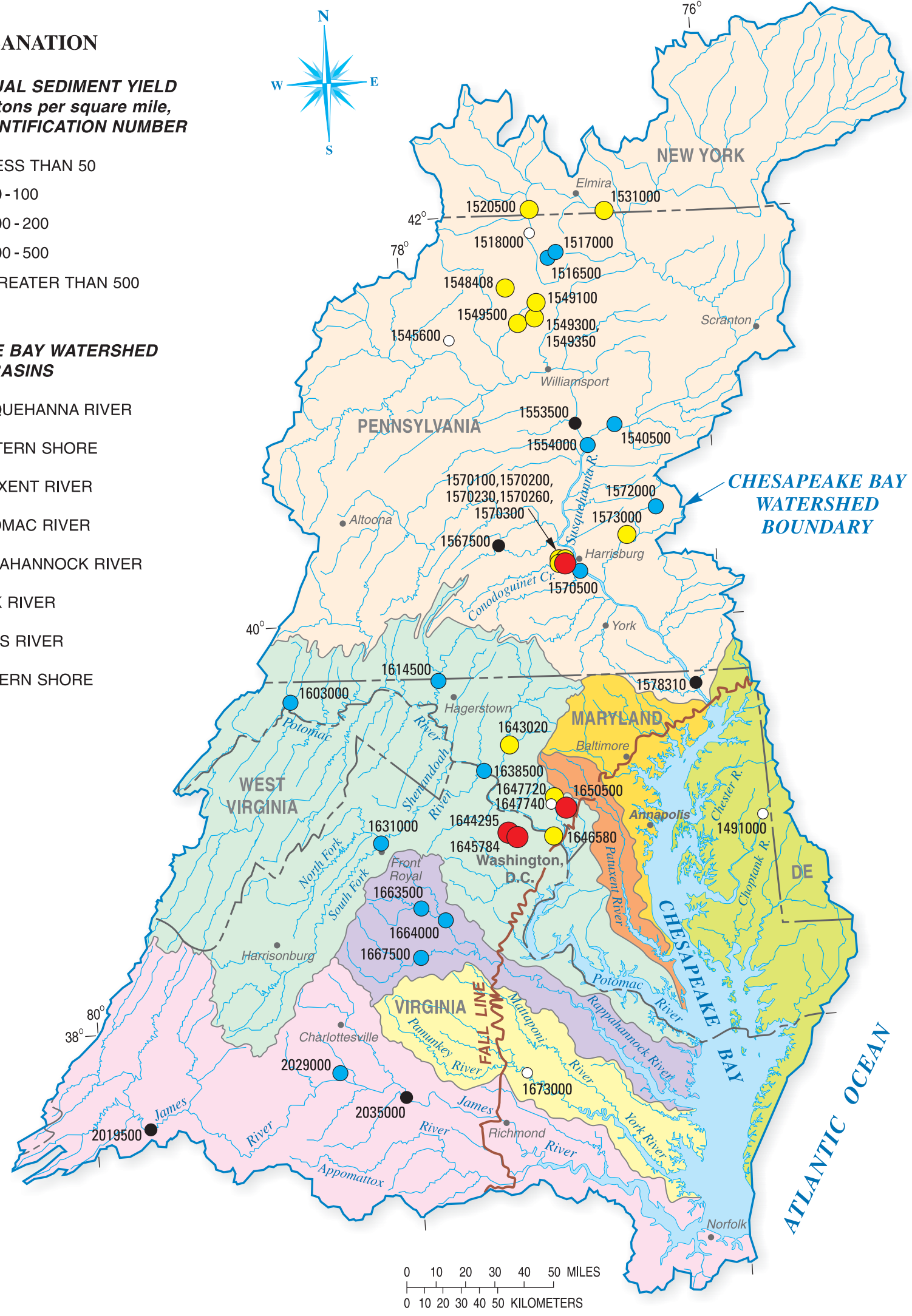

Figure 7b. Average annual sediment yield from 1952 through 1984 for 43 stations in the Chesapeake Bay Watershed with at least 3 years of record. (Refer to table 3 for listing of stations.) 


\section{EXPLANATION}

AVERAGE ANNUAL DISCHARGE-WEIGHTED SEDIMENT CONCENTRATION (1952-1984), in milligrams per liter, and STATION IDENTIFICATION NUMBER

$\begin{array}{ll}1545600 \bigcirc & \text { LESS THAN } 50 \\ 1540500 \bigcirc 50-100 \\ 1517000 \bigcirc 100-200 \\ 1520500 \bigcirc 200-500 \\ 1650500 \bigcirc \text { GREATER THAN } 500\end{array}$

\section{CHESAPEAKE BAY WATERSHED BASINS}

SUSQUEHANNA RIVER

WESTERN SHORE

PATUXENT RIVER

POTOMAC RIVER

RAPPAHANNOCK RIVER

YORK RIVER

JAMES RIVER

EASTERN SHORE
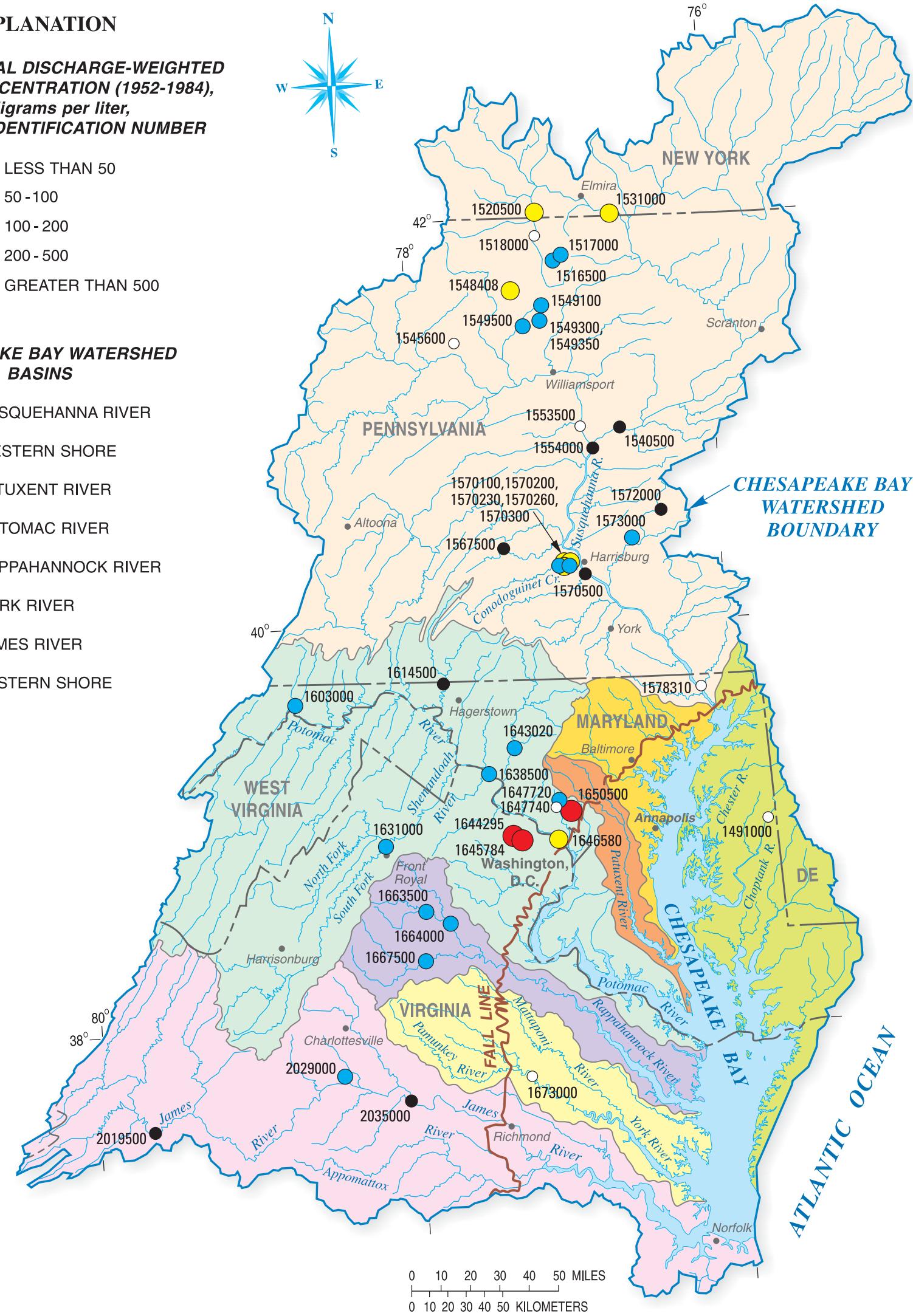

Figure 7c. Average annual discharge-weighted sediment concentration from 1952 through 1984 for 43 stations in the Chesapeake Bay Watershed with at least 3 years of record. (Refer to table 3 for listing of stations.) 
Table 3. Summary of sediment data for water years 1952 through 1984

[USGS daily refers to daily-load sediment stations, Estimator is sediment data from the Estimator model, and RIM is sediment data from the River Input Monitoring Stations. Water Year is from October 1 of the previous year to September 30 of the current year; $\mathrm{mg} / \mathrm{L}$, milligrams per liter]

\section{Period of \\ record for sediment collection \\ (water \\ year)}

Eastern Shore

1972-1984
USGS daily/RIM

USGS daily

USGS daily

Estimator

USGS daily

USGS daily

Estimator

Estimator/USGS daily

USGS daily

USGS daily

USGS daily

USGS daily

USGS daily

USGS daily/Estimator

Estimator

USGS daily

USGS daily

USGS daily

USGS daily

USGS daily

USGS daily

Estimator/USGS daily

USGS daily

USGS daily

Estimator/USGS daily
Choptank River near Greensboro, MD

Corey Creek near Mainesburg, PA

Elk Run near Mainesburg, PA

Tioga River at Tioga, PA

Tioga River at Lindley, NY

Chemung River at Chemung, NY

Susquehanna River at Danville, PA

Young Womans Creek near Renovo, PA

Wilson Creek above Sand Run near Antrim, PA

Blockhouse Creek Tributary at Liberty, PA

Blockhouse Creek at Buttonwood, PA

Steam Valley Run at Buttonwood, PA

Blockhouse Creek near English Center, PA

West Branch Susquehanna River at Lewisburg, PA

Susquehanna River at Sunbury, PA

Bixler Run near Loysville, PA

Conodoguinet Creek Tributary No. 1 near Enola, PA

Conodoguinet Creek Tributary No. 2 near Enola, PA

Conodoguinet Creek Tributary No. 2A near Enola, PA

Conodoguinet Creek Tributary No. 2B near Enola, PA

Conodoguinet Creek Tributary No. 3 near Enola, PA

Susquehanna River at Harrisburg, PA

Lower Little Swatara Creek at Pine Grove, PA

Swatara Creek at Harper Tavern, PA

Susquehanna River at Conowingo, MD

$\begin{array}{ll}\text { Station } & \begin{array}{l}\text { Drainage } \\ \text { area } \\ \text { identification } \\ \text { (square }\end{array} \\ \text { number } & \text { miles) }\end{array}$

01491000

$01516500 \quad 12.2$

$01517000 \quad 10.2$

$01518000 \quad 282$

$01520500 \quad 771$

$01531000 \quad 2,506$

$01540500 \quad 11,220$

$01545600 \quad 46.2$

$01548408 \quad 12.6$

$01549100 \quad 1.08$

$01549300 \quad 22.3$

$01549350 \quad 5.34$

$01549500 \quad 37.7$

$01553500 \quad 6,847$

$01554000 \quad 18,306$

$01567500 \quad 15$

$01570100 \quad 0.77$

$01570200 \quad 0.76$

$01570230 \quad 0.7$

$01570260 \quad 0.65$

$01570300 \quad 0.38$

$01570500 \quad 24,100$

$01572000 \quad 34.3$

$01573000 \quad 337$

$01578310 \quad 27,100$

USGS daily

USGS daily

USGS daily

USGS daily

USGS daily

USGS daily

USGS daily

Estimator/ USGS daily

Estimator

USGS daily

USGS daily

\begin{tabular}{|c|c|c|}
\hline North Branch Potomac River near Cumberland, MD & 01603000 & 877 \\
\hline Conococheague Creek at Fairview, MD & 01614500 & 495 \\
\hline South Fork Shenandoah River at Front Royal, VA & 01631000 & 1,642 \\
\hline Potomac River at Point of Rocks, MD & 01638500 & 9,651 \\
\hline Monocacy River at Reichs Ford Bridge near Frederick, MD & 01643020 & 817 \\
\hline Smilax Branch at Reston, VA & 01644295 & 0.32 \\
\hline Snakeden Branch at Reston, VA & 01645784 & 0.79 \\
\hline Potomac River at Chain Bridge at Washington, D.C. ${ }^{1}$ & 01646580 & 11,570 \\
\hline North Branch Rock Creek near Norbeck, MD & 01647720 & 9.73 \\
\hline North Branch Rock Creek near Rockville, MD & 01647740 & 12.5 \\
\hline Northwest Branch Anacostia River near Colesville, MD & 01650500 & 21.1 \\
\hline
\end{tabular}

1 Discharge is measured at Potomac River near Washington D.C., Little Falls Pumping Station (01646500), 1.2 miles upstream of Chain Bridge. 


\begin{tabular}{|c|c|c|c|c|c|c|c|}
\hline $\begin{array}{l}\text { Average } \\
\text { water year } \\
\text { sediment } \\
\text { load } \\
\text { (tons) }\end{array}$ & $\begin{array}{l}\text { Average } \\
\text { water year } \\
\text { discharge- } \\
\text { weighted } \\
\text { sediment } \\
\text { concentration } \\
(\mathrm{mg} / \mathrm{L})\end{array}$ & $\begin{array}{l}\text { Average } \\
\text { water year } \\
\text { sediment } \\
\text { yield } \\
\text { (tons per } \\
\text { square } \\
\text { mile) }\end{array}$ & $\begin{array}{l}\text { Mean daily } \\
\text { discharge } \\
\text { for sediment } \\
\text { period } \\
\text { (cubic feet } \\
\text { per second) }\end{array}$ & $\begin{array}{l}\text { Mean daily } \\
\text { discharge } \\
\text { for period } \\
\text { of record } \\
\text { (cubic feet } \\
\text { per second) }\end{array}$ & Period of streamflow record & $\begin{array}{l}\text { Difference } \\
\text { of study } \\
\text { period } \\
\text { mean daily } \\
\text { discharge } \\
\text { to period } \\
\text { of record } \\
\text { (in percent) }\end{array}$ & $\begin{array}{l}\text { Station } \\
\text { identification } \\
\text { number }\end{array}$ \\
\hline 2,480 & 16.0 & 21.9 & 156 & 132 & 1949-2002 & 18.4 & 01491000 \\
\hline 1,360 & 138 & 111 & 10.0 & 12.5 & 1955-2001 & -19.9 & 01516500 \\
\hline 1,650 & 149 & 162 & 11.2 & 11.0 & 1955-1978 & 2.0 & 01517000 \\
\hline 11,200 & 25.2 & 39.8 & 451 & 380 & 1939-2001 & 18.7 & 01518000 \\
\hline 310,400 & 325 & 403 & 969 & 812 & 1931-1994 & 19.3 & 01520500 \\
\hline 828,300 & 275 & 331 & 3,056 & 2,578 & 1907-1909, 1912, 1916-2001 & 18.5 & 01531000 \\
\hline $1,431,000$ & 85.2 & 128 & 17,052 & 15,266 & $1906-2001$ & 11.7 & 01540500 \\
\hline 352 & 4.3 & 7.6 & 83.1 & 73.5 & 1966-2001 & 13.1 & 01545600 \\
\hline 4,930 & 386 & 392 & 13.0 & 13.0 & 1979-1981 & -0.2 & 01548408 \\
\hline 317 & 190 & 293 & 1.7 & 1.7 & 1973-1977 & -0.2 & 01549100 \\
\hline 6,420 & 184 & 288 & 35.5 & 35.5 & 1973-1977 & -0.1 & 01549300 \\
\hline 700 & 65.7 & 131 & 10.8 & 10.8 & 1973-1977 & 0.3 & 01549350 \\
\hline 10,300 & 155 & 272 & 67.2 & 58.4 & $1941-2001$ & 15.0 & 01549500 \\
\hline 432,000 & 35.7 & 63 & 12,284 & 10,796 & 1940-2001 & 13.8 & 01553500 \\
\hline $2,192,000$ & 69.7 & 120 & 31,964 & 26,626 & 1938-2001 & 20.0 & 01554000 \\
\hline 999 & 67.3 & 66.6 & 15.1 & 19.5 & 1955-2001 & -22.7 & 01567500 \\
\hline 150 & 133 & 194 & 1.1 & 1.1 & 1970-1976 & 3.6 & 01570100 \\
\hline 283 & 250 & 373 & 1.2 & 1.2 & 1973-1976 & -4.0 & 01570200 \\
\hline 170 & 177 & 243 & 1.0 & 1.0 & 1973-1976 & -0.1 & 01570230 \\
\hline 329 & 335 & 506 & 1.0 & 1.0 & 1973-1976 & -0.3 & 01570260 \\
\hline 160 & 258 & 410 & 0.6 & 0.6 & 1970-1976 & 0.6 & 01570300 \\
\hline $2,880,000$ & 81.3 & 120 & 35,979 & 34,212 & 1891-2001 & 5.2 & 01570500 \\
\hline 5,730 & 81.4 & 167 & 71.5 & 58.2 & 1920-1932, 1982-1984 & 22.9 & 01572000 \\
\hline 104,000 & 139 & 309 & 761 & 572 & $1920-2001$ & 33.1 & 01573000 \\
\hline $1,636,000$ & 44.8 & 60.4 & 37,031 & 39,791 & 1968-2002 & -6.9 & 01578310 \\
\hline 157,000 & 121 & 179 & 1,318 & 1,287 & 1930-2002 & 2.4 & 01603000 \\
\hline 65,900 & 90.1 & 133 & 743 & 597 & 1929-1991, 1993-2002 & 24.4 & 01614500 \\
\hline 225,000 & 174 & 137 & 1,309 & 1,591 & $1931-2001$ & -17.7 & 01631000 \\
\hline $1,145,000$ & 118 & 119 & 9,884 & 9,437 & 1896-2002 & 4.7 & 01638500 \\
\hline 187,000 & 196 & 229 & 965 & 939 & 1943-2002 & 2.7 & 01643020 \\
\hline 316 & 585 & 989 & 0.55 & 0.4 & 1968-1978 & 30.8 & 01644295 \\
\hline 903 & 653 & 1,140 & 1.40 & 1.4 & 1974-1978 & 0.3 & 01645784 \\
\hline $2,918,000$ & 224 & 252 & 13,234 & 11,256 & $1931-2002$ & 17.6 & 01646580 \\
\hline 1,950 & 128 & 201 & 15.6 & 11.8 & 1967-1977 & 31.8 & 01647720 \\
\hline 601 & 37.9 & 48.0 & 16.1 & 16.1 & 1968-1977 & 0.0 & 01647740 \\
\hline 14,800 & 660 & 702 & 22.8 & 22.4 & 1924-1983, 1999-2001 & 1.8 & 01650500 \\
\hline
\end{tabular}


Table 3. Summary of sediment data for water years 1952 through 1984-Continued

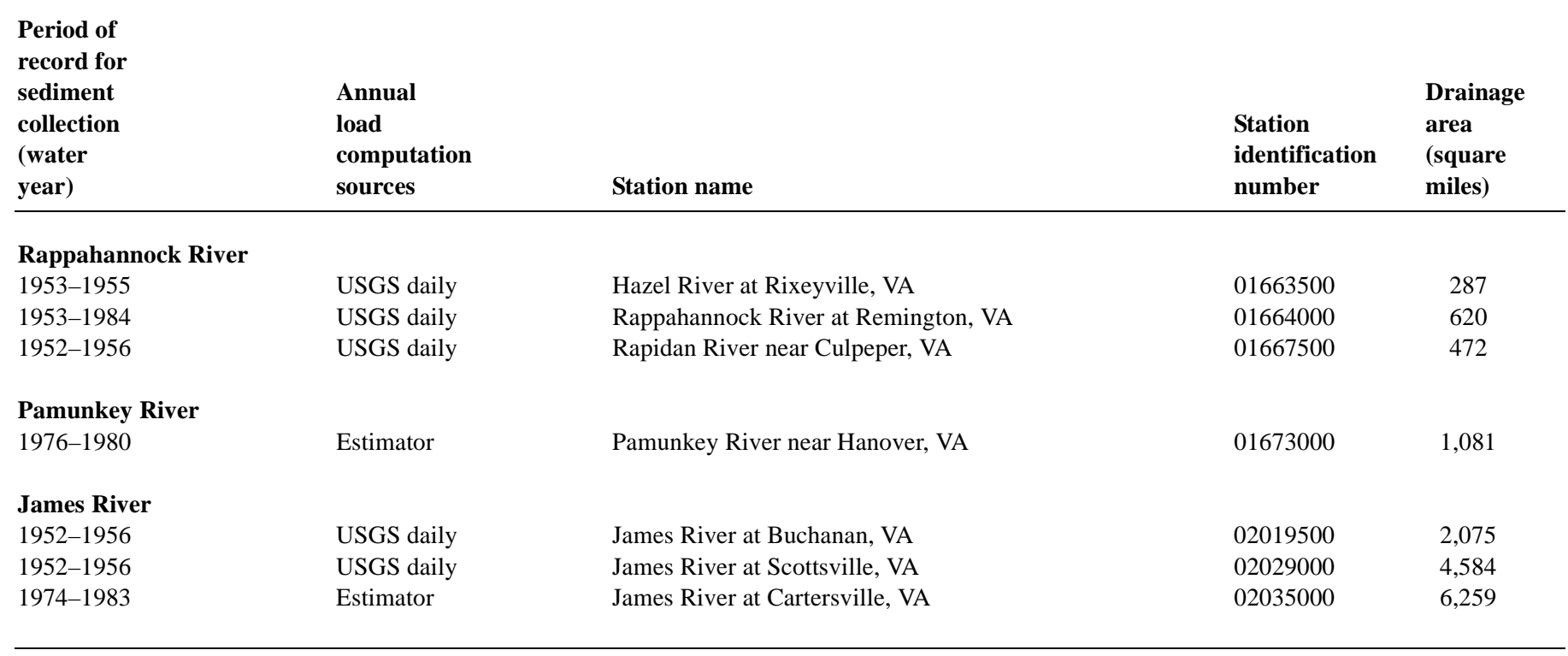




\begin{tabular}{|c|c|c|c|c|c|c|c|}
\hline $\begin{array}{l}\text { Average } \\
\text { water year } \\
\text { sediment } \\
\text { load } \\
\text { (tons) }\end{array}$ & $\begin{array}{l}\text { Average } \\
\text { water year } \\
\text { discharge- } \\
\text { weighted } \\
\text { sediment } \\
\text { concentration } \\
(\mathrm{mg} / \mathrm{L})\end{array}$ & $\begin{array}{l}\text { Average } \\
\text { water year } \\
\text { sediment } \\
\text { yield } \\
\text { (tons per } \\
\text { square } \\
\text { mile) }\end{array}$ & $\begin{array}{l}\text { Mean daily } \\
\text { discharge } \\
\text { for sediment } \\
\text { period } \\
\text { (cubic feet } \\
\text { per second) }\end{array}$ & $\begin{array}{l}\text { Mean daily } \\
\text { discharge } \\
\text { for period } \\
\text { of record } \\
\text { (cubic feet } \\
\text { per second) }\end{array}$ & Period of streamflow record & $\begin{array}{l}\text { Difference } \\
\text { of study } \\
\text { period } \\
\text { mean daily } \\
\text { discharge } \\
\text { to period } \\
\text { of record } \\
\text { (in percent) }\end{array}$ & $\begin{array}{l}\text { Station } \\
\text { identification } \\
\text { number }\end{array}$ \\
\hline 47,800 & 164 & 166 & 295 & 338 & 1943-1992 & -12.6 & 01663500 \\
\hline 98,300 & 148 & 158 & 676 & 693 & 1943-2001 & -2.4 & 01664000 \\
\hline 74,000 & 166 & 157 & 453 & 535 & 1931-2002 & -15.4 & 01667500 \\
\hline 24,100 & 20.2 & 22.3 & 1,211 & 1,010 & 1942-2001 & 19.9 & 01673000 \\
\hline 198,000 & 93.7 & 95.4 & 2,146 & 2,452 & 1911-2001 & -12.5 & 02019500 \\
\hline 623,700 & 136.9 & 136 & 4,623 & 5,208 & 1925-2001 & -11.2 & 02029000 \\
\hline 417,200 & 56.7 & 66.7 & 7,470 & 7,161 & 1900-2001 & 4.3 & 02035000 \\
\hline
\end{tabular}


Table 4. Rankings of sediment loads, yields, and discharge-weighted sediment concentrations, from highest (1) to lowest (43) values, for stations operating from water years 1952 through 1984

\begin{tabular}{|c|c|c|c|c|}
\hline Station name & $\begin{array}{l}\text { Station } \\
\text { identification } \\
\text { numbers }\end{array}$ & $\begin{array}{l}\text { Suspended- } \\
\text { sediment } \\
\text { load } \\
\text { ranking }\end{array}$ & $\begin{array}{l}\text { Sediment } \\
\text { yield } \\
\text { ranking }\end{array}$ & $\begin{array}{l}\text { Discharge-weighted } \\
\text { sediment } \\
\text { concentration } \\
\text { ranking }\end{array}$ \\
\hline Choptank River near Greensboro, MD & 1491000 & 28 & 42 & 42 \\
\hline Corey Creek near Mainesburg, PA & 1516500 & 31 & 33 & 22 \\
\hline Elk Run near Mainesburg, PA & 1517000 & 30 & 22 & 19 \\
\hline Tioga River at Tioga, PA & 1518000 & 23 & 40 & 40 \\
\hline Tioga River at Lindley, NY & 1520500 & 11 & 6 & 6 \\
\hline Chemung River at Chemung, NY & 1531000 & 7 & 9 & 7 \\
\hline Susquehanna River at Danville, PA & 1540500 & 5 & 29 & 30 \\
\hline Young Womans Creek near Renovo, PA & 1545600 & 36 & 43 & 43 \\
\hline Wilson Creek above Sand Run near Antrim, PA & 1548408 & 27 & 7 & 4 \\
\hline Blockhouse Creek Tributary at Liberty, PA & 1549100 & 38 & 11 & 12 \\
\hline Blockhouse Creek at Buttonwood, PA & 1549300 & 25 & 12 & 13 \\
\hline Steam Valley Run at Buttonwood, PA & 1549350 & 34 & 28 & 35 \\
\hline Blockhouse Creek near English Center, PA & 1549500 & 24 & 13 & 18 \\
\hline West Branch Susquehanna River at Lewisburg, PA & 1553500 & 9 & 37 & 39 \\
\hline Susquehanna River at Sunbury, PA & 1554000 & 3 & 30 & 33 \\
\hline Bixler Run near Loysville, PA & 1567500 & 32 & 36 & 34 \\
\hline $\begin{array}{l}\text { Conodoguinet Creek Tributary No. } 1 \\
\text { near Enola, PA }\end{array}$ & 1570100 & 43 & 18 & 24 \\
\hline $\begin{array}{l}\text { Conodoguinet Creek Tributary No. } 2 \\
\text { near Enola, PA }\end{array}$ & 1570200 & 40 & 8 & 9 \\
\hline $\begin{array}{l}\text { Conodoguinet Creek Tributary No. 2A } \\
\text { near Enola, PA }\end{array}$ & 1570230 & 41 & 15 & 14 \\
\hline $\begin{array}{l}\text { Conodoguinet Creek Tributary No. 2B } \\
\text { near Enola, PA }\end{array}$ & 1570260 & 37 & 4 & 5 \\
\hline Conodoguinet Creek Tributary No. 3 near Enola, PA & 1570300 & 42 & 5 & 8 \\
\hline Susquehanna River at Harrisburg, PA & 1570500 & 2 & 31 & 32 \\
\hline Lower Little Swatara Creek at Pine Grove, PA & 1572000 & 26 & 20 & 31 \\
\hline Swatara Creek at Harper Tavern, PA & 1573000 & 16 & 10 & 21 \\
\hline Susquehanna River at Conowingo, MD & 1578310 & 4 & 38 & 37 \\
\hline North Branch Potomac River near Cumberland, MD & 1603000 & 15 & 19 & 26 \\
\hline Conococheague Creek at Fairview, MD & 1614500 & 19 & 27 & 29 \\
\hline South Fork Shenandoah River at Front Royal, VA & 1631000 & 12 & 25 & 15 \\
\hline Potomac River at Point of Rocks, MD & 1638500 & 6 & 32 & 27 \\
\hline $\begin{array}{l}\text { Monocacy River at Reichs Ford Bridge } \\
\text { near Frederick, MD }\end{array}$ & 1643020 & 14 & 16 & 11 \\
\hline Smilax Branch at Reston, VA & 1644295 & 39 & 2 & 3 \\
\hline Snakeden Branch at Reston, VA & 1645784 & 33 & 1 & 2 \\
\hline Potomac River at Chain Bridge at Washington, D.C. & 1646580 & 1 & 14 & 10 \\
\hline North Branch Rock Creek near Norbeck, MD & 1647720 & 29 & 17 & 25 \\
\hline North Branch Rock Creek near Rockville, MD & 1647740 & 35 & 39 & 38 \\
\hline Northwest Branch Anacostia River near Colesville, MD & 1650500 & 22 & 3 & 1 \\
\hline Hazel River at Rixeyville, VA & 1663500 & 20 & 21 & 17 \\
\hline Rappahannock River at Remington, VA & 1664000 & 17 & 23 & 20 \\
\hline Rapidan River near Culpeper, VA & 1667500 & 18 & 24 & 16 \\
\hline Pamunkey River near Hanover, VA & 1673000 & 21 & 41 & 41 \\
\hline James River at Buchanan, VA & 2019500 & 13 & 34 & 28 \\
\hline James River at Scottsville, VA & 2029000 & 8 & 26 & 23 \\
\hline James River at Cartersville, VA & 2035000 & 10 & 35 & 36 \\
\hline
\end{tabular}




\section{EXPLANATION}

\section{AVERAGE ANNUAL SUSPENDED-SEDIMENT LOAD (1985-2001), in tons per year, and STATION IDENTIFICATION NUMBER}

\author{
$1545600 \bigcirc$ LESS THAN 1,000 \\ 1568000 ? $1,000-10,000$ \\ $1614500 \bigcirc 10,000-100,000$ \\ ${ }^{1562000} 100,000-1,000,000$ \\ 1578310 GREATER THAN 1,000,000
}

\section{CHESAPEAKE BAY WATERSHED BASINS}

\section{SUSQUEHANNA RIVER}

WESTERN SHORE

PATUXENT RIVER

POTOMAC RIVER

RAPPAHANNOCK RIVER

YORK RIVER

JAMES RIVER

EASTERN SHORE
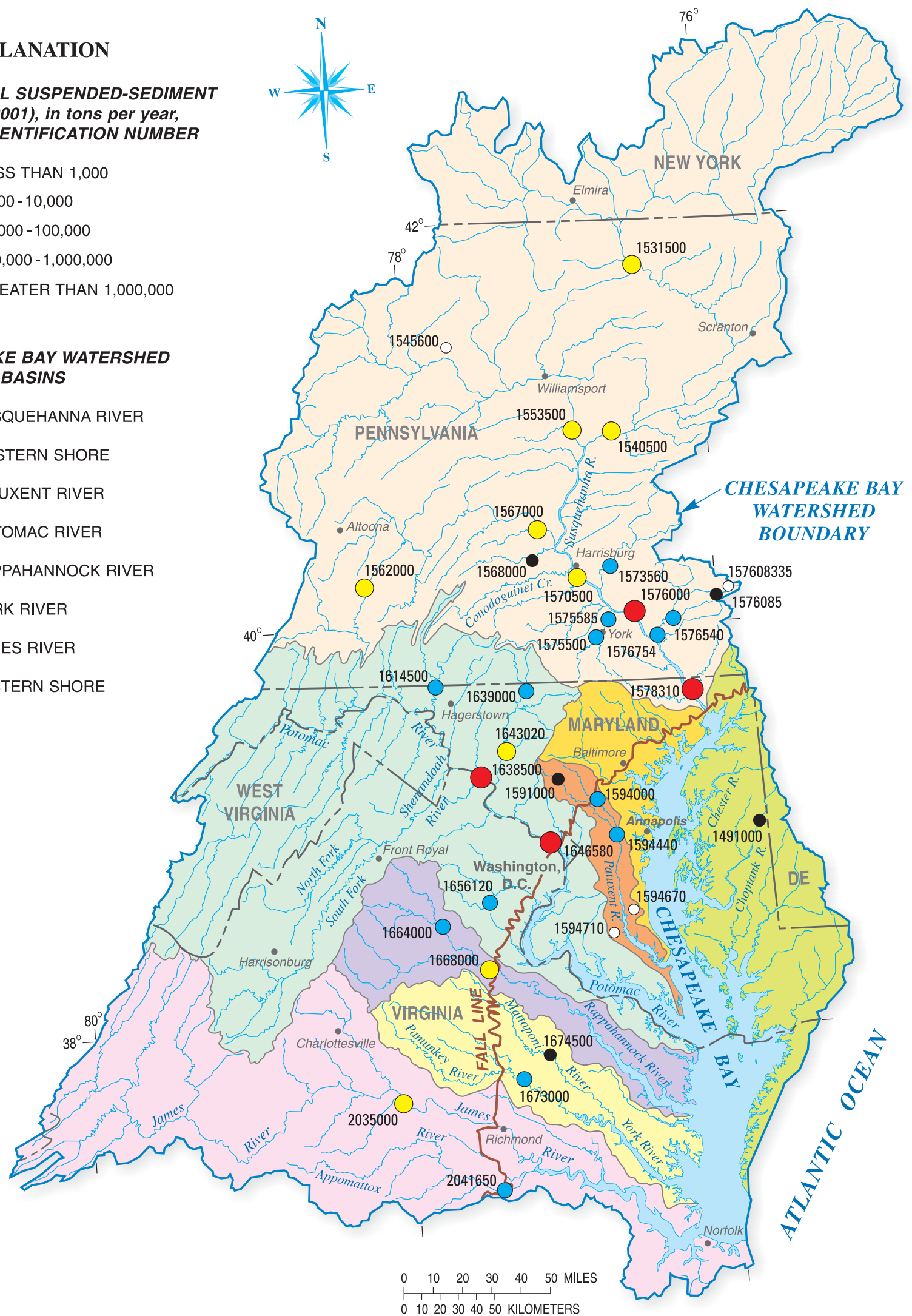

Figure 8a. Average annual suspended-sediment load from 1985 through 2001 for 35 stations in the Chesapeake Bay Watershed with at least 3 years of record. (Refer to table 5 for listing of stations.) 


\section{EXPLANATION}

\section{AVERAGE ANNUAL SEDIMENT YIELD \\ (1985-2001), in tons per square mile, and STATION IDENTIFICATION NUMBER}

$\begin{array}{ll}1545600 \bigcirc & \text { LESS THAN } 50 \\ 1553500 \bigcirc & 50-100 \\ 1639000 \bigcirc & 100-200 \\ 1562000 \bigcirc 200-500 \\ 1576085 \bigcirc \text { GREATER THAN } 500\end{array}$

\section{CHESAPEAKE BAY WATERSHED} BASINS

SUSQUEHANNA RIVER

WESTERN SHORE

PATUXENT RIVER

POTOMAC RIVER

RAPPAHANNOCK RIVER

YORK RIVER

JAMES RIVER

EASTERN SHORE
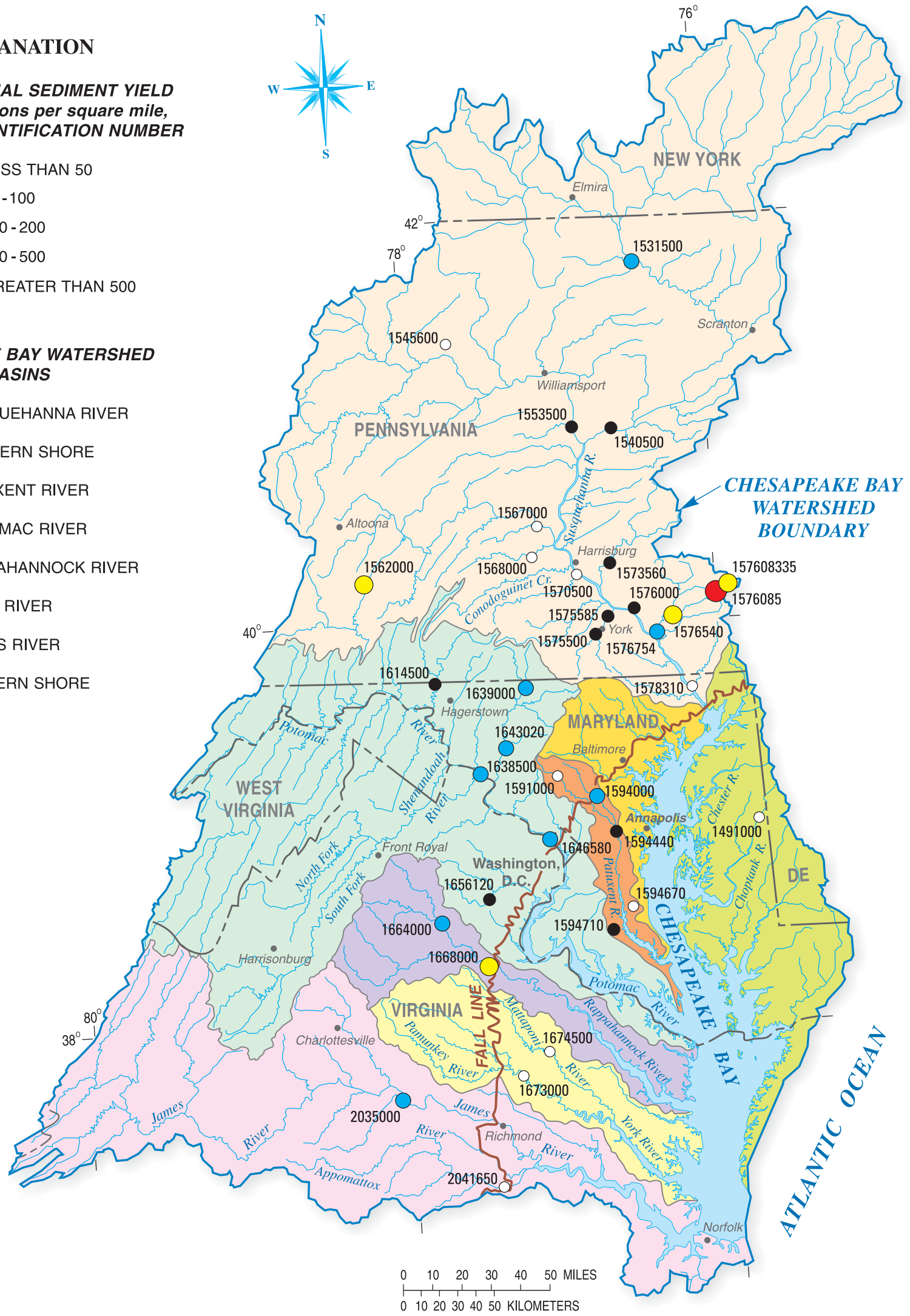

Figure 8b. Average annual sediment yield from 1985 through 2001 for 35 stations in the Chesapeake Bay Watershed with at least 3 years of record. (Refer to table 5 for listing of stations.) 
EXPLANATION

AVERAGE ANNUAL DISCHARGE-WEIGHTED SEDIMENT CONCENTRATION (1985-2001),

in milligrams per liter,

and STATION IDENTIFICATION NUMBER

$\begin{array}{ll}1545600 \bigcirc & \text { LESS THAN } 50 \\ 1540500 & 50-100 \\ 1576754 \bigcirc & 100-200 \\ 1562000 \bigcirc 200-500 \\ 1576085 \bigcirc \text { GREATER THAN } 500\end{array}$

CHESAPEAKE BAY WATERSHED

BASINS

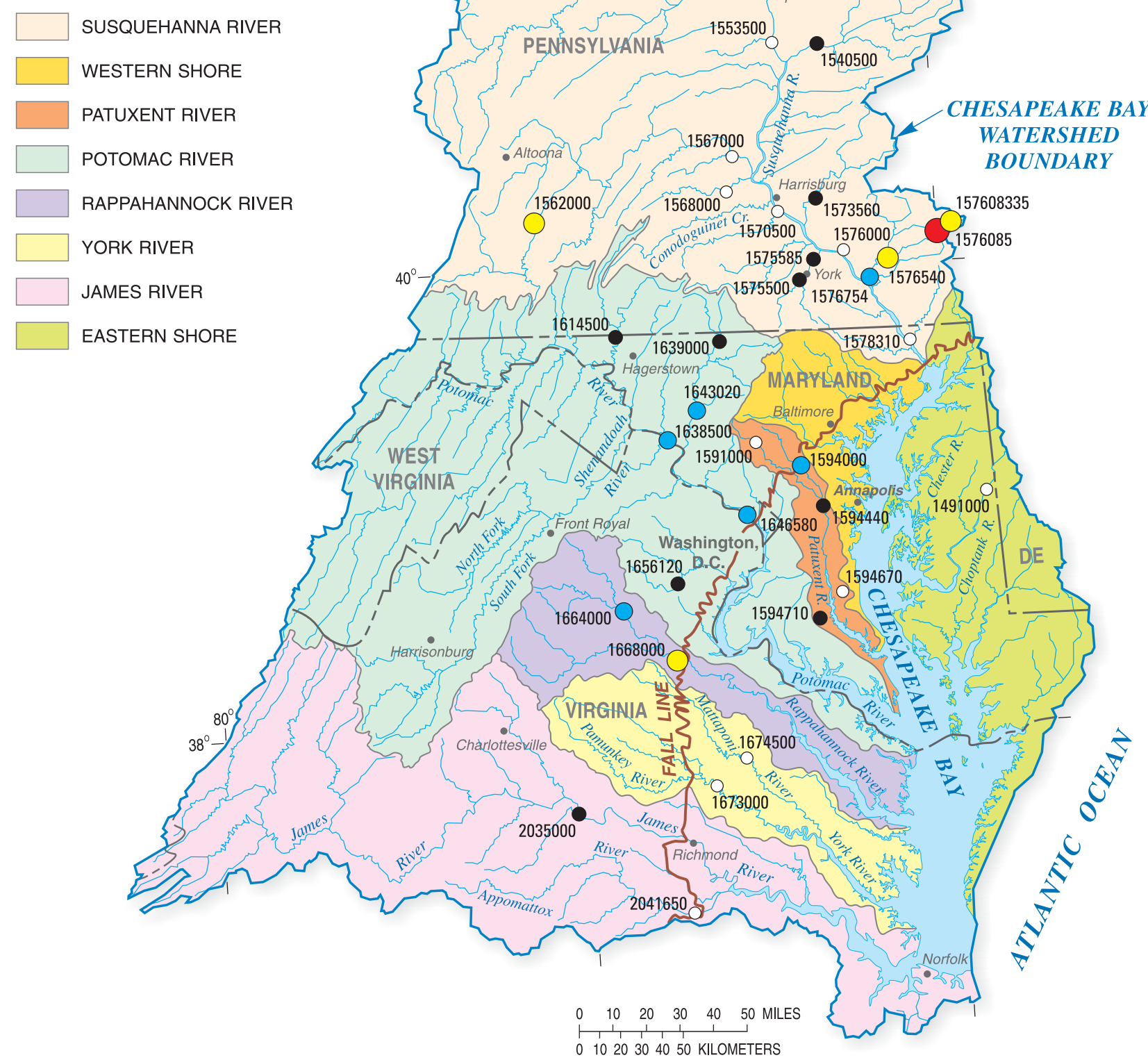

Figure 8c. Average annual discharge-weighted sediment concentration from 1985 through 2001 for 35 stations in the Chesapeake Bay Watershed with at least 3 years of record. (Refer to table 5 for listing of stations.) 
Table 5. Summary of sediment data for water years 1985 through 2001

[USGS daily refers to daily-load sediment stations, Estimator is sediment data from the Estimator model, and RIM is sediment data from the River Input Monitoring Stations. Water Year is from October 1 of the previous year to September 30 of the current year; $\mathrm{mg} / \mathrm{L}$, milligrams per liter]

\begin{tabular}{|c|c|}
\hline $\begin{array}{l}\text { Period of } \\
\text { record for } \\
\text { sediment } \\
\text { collection } \\
\text { (water } \\
\text { year) }\end{array}$ & $\begin{array}{l}\text { Annual } \\
\text { load } \\
\text { computation } \\
\text { sources }\end{array}$ \\
\hline \multicolumn{2}{|l|}{ Eastern Shore } \\
\hline 1985-2001 & $\begin{array}{l}\text { Estimator/ USGS daily } \\
\text { /RIM }\end{array}$ \\
\hline \multicolumn{2}{|l|}{ Susquehanna River } \\
\hline 1985-1996 & Estimator \\
\hline 1985-1996 & USGS daily/Estimator \\
\hline 1985-1992 & Estimator \\
\hline 1989-1996 & Estimator \\
\hline 1988-1992 & Estimator \\
\hline 1985-1996 & Estimator \\
\hline 1985-1996 & Estimator \\
\hline 1985-1991 & Estimator \\
\hline 1985-1989 & Estimator \\
\hline 1985-1989 & Estimator \\
\hline 1985-1989 & Estimator \\
\hline 1985-1996 & Estimator \\
\hline 1985-1992 & Estimator \\
\hline 1993-1995 & Estimator \\
\hline 1985-1998, 2001 & Estimator \\
\hline 1985-2001 & Estimator/ USGS daily \\
\hline 1986, 1988-1991 & Estimator \\
\hline \multicolumn{2}{|l|}{ Patuxent River } \\
\hline 1986, 1990, 1993, 1995 & Estimator \\
\hline 1987, 1988, 1990 & Estimator \\
\hline 1985-2001 & USGS daily/RIM \\
\hline 1989-1992 & Estimator \\
\hline $\begin{array}{l}\text { 1986-1989, 1991, } \\
\text { 1994-1996 }\end{array}$ & Estimator \\
\hline \multicolumn{2}{|l|}{ Potomac River } \\
\hline 1993-1996 & Estimator \\
\hline 1985-1992 & USGS daily \\
\hline 1989-1995 & Estimator/ USGS daily \\
\hline 1985-1992 & USGS daily \\
\hline 1985-2001 & RIM data \\
\hline 1997-1999 & USGS daily \\
\hline
\end{tabular}

Station name

Choptank River near Greensboro, MD

01491000

113

Susquehanna River at Towanda, PA 1

01531500

7,797

Susquehanna River at Danville, PA 1

Young Womans Creek near Renovo, PA

01540500

11,220

West Branch Susquehanna River at Lewisburg, PA ${ }^{1}$

01545600

46.0

Raystown Branch Juniata River at Saxton, PA

01553500

6,847

Juniata River at Newport, PA ${ }^{1}$

01562000

756

Sherman Creek at Shermans Dale, PA ${ }^{1}$

01567000

3,355

Susquehanna River at Harrisburg, PA 1

01568000

01570500

200

Swatara Creek near Hershey, $\mathrm{PA}^{\mathbf{1}}$

01573560

24,100

Codorus Creek near York, PA ${ }^{1}$

01575500

483

Codorus Creek at Pleasureville, PA 1

Susquehanna River at Marietta, PA 1

Little Conestoga Creek near Churchtown, PA

Mill Creek at Eshelman Mill Road near Lyndon, PA

Conestoga River at Conestoga, PA 1

Susquehanna River at Conowingo, MD

Little Conestoga Creek site 3A near Morgantown, PA

01575585

01576000

267

01576085

25,998

01576540

01576754

01578310

0157608335

5.82

54.0

470

27,100

1.42

Patuxent River near Unity, MD

Little Patuxent River at Savage, MD

01591000

01594000

34.8

Patuxent River near Bowie, MD

Hunting Creek near Huntingtown, MD

01594440

01594670

01594710

9.38

Killpeck Creek at Huntersville, MD

Conococheague Creek at Fairview, MD

01614500

494

Potomac River at Point of Rocks, MD

01638500

9,651

Monocacy River at Bridgeport, MD

01639000

173

Monocacy River at Reichs Ford Bridge

01643020

817

near Frederick, MD

Potomac River at Chain Bridge at Washington, D.C. ${ }^{2}$

01646580

11,570

Cedar Run at Route 646 near Aden, VA
01656120

\footnotetext{
1 USGS sediment samples were augmented with sediment data collected by Susquehanna River Basin Commission.

2 Discharge is measured at Potomac River near Washington D.C., Little Falls Pumping Station (01646500), 1.2 miles upstream of Chain Bridge.
} 


\begin{tabular}{|c|c|c|c|c|c|c|c|}
\hline $\begin{array}{l}\text { Average } \\
\text { water year } \\
\text { sediment } \\
\text { load } \\
\text { (tons) }\end{array}$ & $\begin{array}{l}\text { Average } \\
\text { water year } \\
\text { discharge- } \\
\text { weighted } \\
\text { sediment } \\
\text { concentration } \\
\text { (mg/L) }\end{array}$ & $\begin{array}{l}\text { Average } \\
\text { water year } \\
\text { sediment } \\
\text { yield } \\
\text { (tons per } \\
\text { square } \\
\text { mile) }\end{array}$ & $\begin{array}{l}\text { Mean daily } \\
\text { discharge } \\
\text { for sediment } \\
\text { period } \\
\text { (cubic feet } \\
\text { per second) }\end{array}$ & $\begin{array}{l}\text { Mean daily } \\
\text { discharge } \\
\text { for period } \\
\text { of record } \\
\text { (cubic feet } \\
\text { per second) }\end{array}$ & Period of streamflow record & 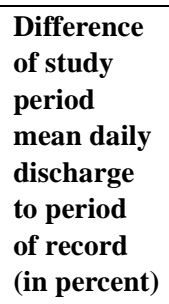 & $\begin{array}{l}\text { Station } \\
\text { identification } \\
\text { number }\end{array}$ \\
\hline 2,310 & 17.3 & 20.4 & 135 & 132 & 1949-2002 & 2.3 & 01491000 \\
\hline 808,000 & 77.3 & 104 & 10,600 & 10,600 & 1914-2001 & 0 & 01531500 \\
\hline 778,000 & 54.5 & 69.3 & 14,500 & 15,300 & 1906-2001 & -5.2 & 01540500 \\
\hline 840 & 12.6 & 18.2 & 67.6 & 73.5 & $1966-2001$ & -8.1 & 01545600 \\
\hline 352,000 & 33.4 & 51.4 & 10,700 & 10,800 & 1940-2001 & -0.9 & 01553500 \\
\hline 196,000 & 247 & 259 & 807 & 921.0 & $1912-2001$ & -12.4 & 01562000 \\
\hline 110,000 & 26.2 & 33.0 & 4,280 & 4,300 & $1900-2001$ & -0.5 & 01567000 \\
\hline 7,640 & 29.8 & 38.2 & 260.0 & 292.0 & 1930-2001 & -11.0 & 01568000 \\
\hline 765,000 & 25.3 & 31.8 & 30,700 & 34,200 & $1891-2001$ & -10.2 & 01570500 \\
\hline 41,400 & 64.4 & 85.6 & 652 & 781 & $1976-2001$ & -16.5 & 01573560 \\
\hline 14,400 & 81.8 & 64.6 & 178 & 223 & 1941-1996 & -20.1 & 01575500 \\
\hline 17,800 & 70.8 & 66.5 & 255 & 254 & 1985-1989 & 0.2 & 01575585 \\
\hline $1,700,000$ & 47.2 & 65.4 & 36,600 & 37,000 & $1932-2001$ & -1.1 & 01576000 \\
\hline 6,100 & 1,044 & 1,050 & 5.9 & 7.3 & 1983-1995 & -18.9 & 01576085 \\
\hline 17,400 & 223 & 321 & 79 & 81 & 1993-1998 & -1.5 & 01576540 \\
\hline 81,800 & 133 & 173.9 & 625 & 640 & $1985-2001$ & -2.4 & 01576754 \\
\hline $1,107,000$ & 29.9 & 40.8 & 37,600 & 39,800 & 1968-2002 & -5.5 & 01578310 \\
\hline 470 & 391 & 331 & 1.2 & 1.1 & $1985-1991$ & 10.9 & 0157608335 \\
\hline 1,380 & 40.2 & 39.6 & 34.8 & 38.8 & 1945-2002 & -10.2 & 01591000 \\
\hline 10,200 & 111 & 104 & 94 & 109 & $\begin{array}{l}\text { 1940-1958, 1976-1980, } \\
\text { 1986-2002 }\end{array}$ & -13.9 & 01594000 \\
\hline 23,000 & 66.0 & 66.2 & 355 & 367 & $1978-2002$ & -3.3 & 01594440 \\
\hline 122 & 12.3 & 13.0 & 10.1 & 10.5 & 1989-1997 & -4.2 & 01594670 \\
\hline 304 & 84.9 & 32.4 & 3.6 & 3.9 & $1986-1997$ & -6.7 & 01594710 \\
\hline 45,500 & 52.2 & 92 & 885 & 597 & 1929-1991, 1993-2002 & 48.2 & 01614500 \\
\hline $1,128,000$ & 136 & 117 & 8,430 & 9,440 & 1896-2002 & -10.7 & 01638500 \\
\hline 19,800 & 84.7 & 115 & 238 & 207 & $1943-2002$ & 14.9 & 01639000 \\
\hline 108,000 & 138 & 133 & 797 & 939 & $1943-2002$ & -15.1 & 01643020 \\
\hline $1,844,000$ & 157 & 159 & 11,900 & 11,300 & 1931-2002 & 5.3 & 01646580 \\
\hline 11,500 & 64.9 & 66 & 179 & 179 & 1997-1999 & 0 & 01656120 \\
\hline
\end{tabular}


Table 5. Summary of sediment data for water years 1985 through 2001—Continued

\begin{tabular}{|c|c|c|c|c|}
\hline $\begin{array}{l}\text { Period of } \\
\text { record for } \\
\text { sediment } \\
\text { collection } \\
\text { (water } \\
\text { year) }\end{array}$ & $\begin{array}{l}\text { Annual } \\
\text { load } \\
\text { computation } \\
\text { sources }\end{array}$ & Station name & $\begin{array}{l}\text { Station } \\
\text { identification } \\
\text { number }\end{array}$ & $\begin{array}{l}\text { Drainage } \\
\text { area } \\
\text { (square } \\
\text { miles) }\end{array}$ \\
\hline \multicolumn{5}{|c|}{ Rappahannock River } \\
\hline 1985-1993 & USGS daily & Rappahannock River at Remington,VA & 01664000 & 620 \\
\hline 1989-2001 & RIM data & Rappahannock River near Fredericksburg, VA* & 01668000 & 1,596 \\
\hline \multicolumn{5}{|c|}{ Pamunkey River } \\
\hline 1990-2001 & RIM data & Pamunkey River near Hanover, VA* & 01673000 & 1,081 \\
\hline \multicolumn{5}{|c|}{ Mattaponi River } \\
\hline 1991-2001 & RIM data & Mattaponi River near Beulahville, VA* & 01674500 & 601 \\
\hline \multicolumn{5}{|c|}{ James River } \\
\hline 1987-2001 & Estimator/ RIM data & James River at Cartersville, VA* & 02035000 & 6,259 \\
\hline \multicolumn{5}{|c|}{ Appomattox River } \\
\hline 1990-2001 & RIM data & Appomattox River at Matoaca, VA* & 02041650 & 1,340 \\
\hline
\end{tabular}

\footnotetext{
* Indicates total suspended solids used.
} 


\begin{tabular}{|c|c|c|c|c|c|c|c|}
\hline $\begin{array}{l}\text { Average } \\
\text { water year } \\
\text { sediment } \\
\text { load } \\
\text { (tons) }\end{array}$ & $\begin{array}{l}\text { Average } \\
\text { water year } \\
\text { discharge- } \\
\text { weighted } \\
\text { sediment } \\
\text { concentration } \\
(\mathrm{mg} / \mathrm{L})\end{array}$ & $\begin{array}{l}\text { Average } \\
\text { water year } \\
\text { sediment } \\
\text { yield } \\
\text { (tons per } \\
\text { square } \\
\text { mile) }\end{array}$ & $\begin{array}{l}\text { Mean daily } \\
\text { discharge } \\
\text { for sediment } \\
\text { period } \\
\text { (cubic feet } \\
\text { per second) }\end{array}$ & $\begin{array}{l}\text { Mean daily } \\
\text { discharge } \\
\text { for period } \\
\text { of record } \\
\text { (cubic feet } \\
\text { per second) }\end{array}$ & Period of streamflow record & $\begin{array}{l}\text { Difference } \\
\text { of study } \\
\text { period } \\
\text { mean daily } \\
\text { discharge } \\
\text { to period } \\
\text { of record } \\
\text { (in percent) }\end{array}$ & $\begin{array}{l}\text { Station } \\
\text { identification } \\
\text { number }\end{array}$ \\
\hline 96,800 & 152 & 156 & 645 & 693 & 1943-2001 & -6.9 & 01664000 \\
\hline 527,000 & 299 & 330 & 1,790 & 1,670 & 1908-2001 & 7.2 & 01668000 \\
\hline 39,400 & 38.5 & 36.5 & 1,040 & 1,010 & 1942-2001 & 3.0 & 01673000 \\
\hline 5,030 & 10.0 & 8.4 & 512 & 577 & 1942-1987, 1990-2001 & -11.3 & 01674500 \\
\hline 720,000 & 98.7 & 115 & 7,400 & 7,160 & $1900-2001$ & 3.4 & 02035000 \\
\hline 17,800 & 15.1 & 13.3 & 1,200 & 1,350 & $1970-2001$ & -11.1 & 02041650 \\
\hline
\end{tabular}


Table 6. Rankings of sediment loads, yields, and discharge-weighted sediment concentrations, from highest (1) to lowest (43) values, for stations operating from water years 1985 through 2001

\begin{tabular}{|c|c|c|c|c|}
\hline Station name & $\begin{array}{l}\text { Station } \\
\text { identification } \\
\text { number }\end{array}$ & $\begin{array}{l}\text { Suspended- } \\
\text { sediment load } \\
\text { ranking }\end{array}$ & $\begin{array}{l}\text { Sediment } \\
\text { yield } \\
\text { ranking }\end{array}$ & $\begin{array}{l}\text { Discharge- } \\
\text { weighted } \\
\text { sediment } \\
\text { concentration } \\
\text { ranking }\end{array}$ \\
\hline Susquehanna River at Conowingo, MD & 01578310 & 4 & 24 & 27 \\
\hline Susquehanna River at Marietta, PA & 01576000 & 2 & 21 & 23 \\
\hline Susquehanna River at Harrisburg, PA & 01570500 & 7 & 30 & 30 \\
\hline Susquehanna River at Danville, PA & 01540500 & 6 & 17 & 21 \\
\hline Potomac River at Chain Bridge at Washington, D.C. & 01646580 & 1 & 7 & 6 \\
\hline West Branch Susquehanna River at Lewisburg, PA & 01553500 & 10 & 23 & 26 \\
\hline Susquehanna River at Towanda, PA & 01531500 & 5 & 14 & 16 \\
\hline Potomac River at Point of Rocks, MD & 01638500 & 3 & 10 & 9 \\
\hline James River at Cartersville, VA* & 02035000 & 8 & 11 & 12 \\
\hline Juniata River at Newport, PA & 01567000 & 12 & 28 & 29 \\
\hline Rappahannock River near Fredericksburg, VA* & 01668000 & 9 & 3 & 3 \\
\hline Appomattox River at Matoaca, VA* & 02041650 & 22 & 33 & 32 \\
\hline Pamunkey River near Hanover, VA* & 01673000 & 18 & 27 & 25 \\
\hline Conococheague Creek at Fairview, MD & 01614500 & 16 & 15 & 22 \\
\hline Raystown Branch Juniata River at Saxton, PA & 01562000 & 11 & 5 & 4 \\
\hline Monocacy River at Reichs Ford Bridge near Frederick, MD & 01643020 & 13 & 9 & 8 \\
\hline Swatara Creek near Hershey, PA & 01573560 & 17 & 16 & 20 \\
\hline Rappahannock River at Remington, VA & 01664000 & 14 & 8 & 7 \\
\hline Conestoga River at Conestoga, PA & 01576754 & 15 & 6 & 10 \\
\hline Mattaponi River at Beulahville, VA* & 01674500 & 29 & 35 & 35 \\
\hline Patuxent River near Bowie, MD & 01594440 & 19 & 19 & 18 \\
\hline Sherman Creek at Shermans Dale, PA & 01568000 & 27 & 26 & 28 \\
\hline Codorus Creek at Pleasureville, PA & 01575585 & 21 & 18 & 17 \\
\hline Monocacy River at Bridgeport, MD & 01639000 & 20 & 12 & 14 \\
\hline Cedar Run at Route 646 near Aden, VA & 01656120 & 25 & 20 & 19 \\
\hline Codorus Creek near York, PA & 01575500 & 24 & 22 & 15 \\
\hline Choptank River near Greensboro, MD & 01491000 & 30 & 31 & 31 \\
\hline Little Patuxent River at Savage, MD & 01594000 & 26 & 13 & 11 \\
\hline Mill Creek at Eshelman Mill Road near Lyndon, PA & 01576540 & 23 & 4 & 5 \\
\hline Young Womans Creek near Renovo, PA & 01545600 & 32 & 32 & 33 \\
\hline Patuxent River near Unity, MD & 01591000 & 31 & 25 & 24 \\
\hline Hunting Creek near Huntingtown, MD & 01594670 & 35 & 34 & 34 \\
\hline Little Conestoga Creek near Churchtown, PA & 01576085 & 28 & 1 & 1 \\
\hline Killpeck Creek at Huntersville, MD & 01594710 & 34 & 29 & 13 \\
\hline Little Conestoga Creek site 3A near Morgantown, PA & 0157608335 & 33 & 2 & 2 \\
\hline
\end{tabular}

\footnotetext{
* Indicates total suspended solids were collected at the station.
} 


\section{Instantaneous Suspended-Sediment Concentrations}

From October 1, 1984 through September 30, 2002, 51 stations had at least 3 years of instantaneous suspendedsediment concentrations with at least 10 measurements in each year (fig. 9), totaling 25,572 instantaneous measurements of suspended sediment. No stations meeting these criteria were found in West Virginia or New York. Drainagearea sizes for the 51 stations ranged from 0.36 to over $27,000 \mathrm{mi}^{2}$.

Seven of the 51 stations showed no statistical difference between the median mean-daily discharges on the days when suspended-sediment samples were collected and the median mean-daily discharge for the entire period of sediment record (p-values greater than or equal to 0.05) (table 7). At 42 of the remaining 44 stations, the median of mean-daily discharges was higher for the sample population (table 7).

The $10^{\text {th }}, 50^{\text {th }}$, and $90^{\text {th }}$ percentiles of suspended-sediment concentration were calculated for each station (figs. $10 \mathrm{a}-\mathrm{c}$, table 7). The five sediment stations with the highest suspended-sediment concentrations at the $10^{\text {th }}$ percentile were for rivers draining to the Susquehanna River in Pennsylvania (Brush Run, site 2, near McSherrystown; Codorus Creek at Pleasureville; Conestoga River at Conestoga; and Little Conestoga Creek near Churchtown), and one station draining to the Potomac River in Virginia (Cannon Creek near Garrisonville) (fig. 10a, tables 7-8). The $10^{\text {th }}$ percentile of suspended-sediment concentrations may reflect low-flow conditions. Three of the five sediment stations with the highest suspended-sediment concentration at the $50^{\text {th }}$ percentile included the same stations in Pennsylvania as the $10^{\text {th }}$ percentile (Conestoga River at Conestoga, Codorus Creek at Pleasureville, and Little Conestoga Creek near Churchtown), another station in Pennsylvania (Paxton Creek near Penbrook), and one station in Maryland draining to the Patuxent River (Killpeck Creek at Huntersville, Maryland) (fig. 10b, tables 7-8). At the $90^{\text {th }}$ percentile, the five highest suspended-sediment concentrations included four stations in Pennsylvania draining to the Susquehanna River (Bald Eagle Creek near Fawn Grove, Little Conestoga Creek near Churchtown, Mill Creek at Eshelman Mill Road near Lyndon, and Pequea Creek at Martic Forge), and the same station in Maryland with high sediment concentration at the $50^{\text {th }}$ percentile, draining to the Patuxent River (Killpeck Creek at Huntersville, Maryland) (fig. 10c, tables 7-8). The Little Conestoga Creek near Churchtown was the highest for the $10^{\text {th }}, 50^{\text {th }}$, and $90^{\text {th }}$ percentiles (figs. $10 \mathrm{a}-\mathrm{c}$, tables 5 and 8). The lowest suspended-sediment concentration at the $10^{\text {th }}, 50^{\text {th }}$, and $90^{\text {th }}$ percentiles was at Bobs Creek near Pavia, Pennsylvania, in the Susquehanna River Basin, which drains close to 100 percent forested land (Langland and others, 1999) (figs. 10a-c, tables 5 and 8).

\section{Sediment-Transport Curves}

Suspended-sediment transport curves were generated for the 51 stations in the Chesapeake Bay Watershed with at least 3 complete years of data and at least 10 suspended-sed- iment samples in a given year (figs. 9, 11 a-e, and table 7). The least-squares regression coefficient generated for all plots ranges from 0.02 to 0.81 and averages 0.48 (figs. 11 a$\mathrm{e}$, table 7). The scatter in the sediment-transport curves illustrates that one or more factors other than discharge are controlling suspended-sediment concentrations. The scatter in sediment-transport curves can be related to a number of factors including seasonality, land use, hysteresis, and natural climatic variability (Walling and Webb, 1982).

Normalizing instantaneous discharge by drainage area and plotting the transport curves by drainage-area classes (fig. 12) shows that for the larger drainage areas (classes A and $B$, see page 10 ), the best-fit lines plot close together (figs. $12 \mathrm{a}-\mathrm{b}$ ), and have similar suspended-sediment concentrations with respect to the normalized discharge. The Susquehanna River at Conowingo, Maryland (Class A) and the West Branch Susquehanna River at Lewisburg, Pennsylvania (Class B) show the lowest suspended-sediment concentrations at higher normalized discharges (figs. $12 \mathrm{a}-\mathrm{b}$ ). The graph of Class $\mathrm{C}$ rivers shows the Conestoga River at Conestoga, Pennsylvania, with high suspended-sediment concentrations at high normalized discharges (fig. 12c). The graph of Class D rivers shows two stations draining to the Susquehanna River with high suspended-sediment concentrations at median to high normalized discharges (Codorus Creek at Pleasureville, Pennsylvania, and Codorus Creek near York, Pennsylvania) (fig. 12d). The graph of Class E rivers shows Pequea Creek at Martic Forge, Pennsylvania, with the highest suspended-sediment concentrations at nearly all normalized discharges (fig. 12e). Pequea Creek is a tributary to the Susquehanna River. The graph of Class F rivers shows Mill Creek, a tributary to the Conestoga River, with the highest suspended-sediment concentrations at median to high discharges (fig. 12f). The graph of Class $G$ rivers shows several rivers grouped together with high suspended-sediment concentrations at medium to high normalized discharges: Muddy Creek and Cannon Creek in the Potomac River Basin, and Cedar Run and Paxton Creek in the Susquehanna River Basin (fig. 12g). The lowest suspended-sediment concentrations for Class $\mathrm{G}$ rivers are at Bobs Creek near Pavia, Pennsylvania (fig. 12g). For Class $\mathrm{H}$, five rivers plot close together and show high suspendedsediment concentrations at high normalized discharges in the Susquehanna River Basin (Little Conestoga Creek, Bald Eagle Creek, Big Spring Run, and an unnamed tributary to Big Spring Run, Pennsylvania) and Killpeck Creek near Huntersville, Maryland, in the Patuxent River Basin (fig. 12).

For five of the eight drainage area classes of rivers (Classes C, D, E, F, and H), five stations that drain to the Susquehanna River have the highest suspended-sediment concentrations at high discharges (Class C-Conestoga River, Class D-Codorus Creek, Class E-Pequea Creek, Class FMill Creek, and Class H-Little Conestoga Creek). Three of the five stations drain to the Conestoga River in Pennsylvania (Little Conestoga Creek near Churchtown; Mill Creek at Eshelman Mill Road near Lyndon; and Conestoga River at Conestoga). 
Table 7. Summary of instantaneous suspended-sediment concentration data for stations used in this report for water years 1985 through 2002, including $10^{\text {th }}$, 50 th , and $90^{\text {th }}$ percentiles

\begin{abstract}
[Wilcoxon P-value, sediment transport equation (slope, intercept, and regression coefficient), and drainage area class are also shown. The Mann-Whitney-Wilcoxon tests the difference between the mean-daily discharge on days of suspended-sediment samples versus the mean-daily discharge for the entire water years of sediment record. P-values less than 0.05 indicate the two populations are statistically different; mg/L, milligrams per liter, $\mathrm{ft}^{3} / \mathrm{s}$, cubic feet per second; $\mathrm{R}^{2}$-Pearson product-moment correlation coefficient]
\end{abstract}

Station name

\begin{tabular}{lllll}
$\begin{array}{l}\text { Station } \\
\text { identification } \\
\text { number }\end{array}$ & $\begin{array}{l}\text { Years } \\
\text { of } \\
\text { record }\end{array}$ & $\begin{array}{l}\text { Number } \\
\text { of } \\
\text { samples }\end{array}$ & $\begin{array}{l}\text { Area } \\
\text { (square } \\
\text { miles) }\end{array}$ & $\begin{array}{l}\text { suspended- } \\
\text { sediment } \\
\text { concentration } \\
(\mathbf{m g} / \mathrm{L})\end{array}$ \\
\hline
\end{tabular}

\section{Eastern Shore}

Nassawango Creek near Snow Hill, MD

Nanticoke River near Bridgeville, DE

Choptank River near Greensboro, MD

Chesterville Branch near Crumpton, MD

\section{Susquehanna River}

Susquehanna River at Towanda, PA

Susquehanna River at Danville, PA

West Branch Susquehanna River at Lewisburg, PA

East Mahantango Creek at Klingerstown, PA

Bobs Creek near Pavia, PA

Raystown Branch Juniata River at Saxton, PA

Juniata River at Newport, PA

Sherman Creek at Shermans Dale, PA

Conodoguinet Creek near Hogestown, PA

Susquehanna River at Harrisburg, PA

Paxton Creek near Penbrook, PA

Cedar Run at Eberlys Mill, PA

Swatara Creek near Hershey, PA

Brush Run Site 2 near McSherrystown, PA

West Conewago Creek near Manchester, PA

Codorus Creek near York, PA

Codorus Creek at Pleasureville, PA

Susquehanna River at Marietta, PA

Little Conestoga Creek near Churchtown, PA

Big Spring Run near Willow Street, PA

North Fork Unnamed Tributary to Big Spring Run at Lampeter, PA

Unnamed tributary to Big Spring Run near Lampeter, PA

Mill Creek at Eshelman Mill Road near Lyndon, PA

Conestoga River at Conestoga, PA

Pequea Creek at Martic Forge, PA

Bald Eagle Creek near Fawn Grove, PA

Susquehanna River at Conowingo, MD

\section{Patuxent River}

Patuxent River near Unity, MD

Little Patuxent River at Savage, MD

Patuxent River near Bowie, MD

Western Branch at Upper Marlboro, MD

Hunting Creek near Huntingtown, MD

Killpeck Creek at Huntersville, MD
0148550
0148700
0149100
01493112

01531500

01540500

01553500

01555400

01559795

01562000

01567000

01568000

01570000

01570500

01571000

01571490

01573560

01573810

01574000

01575500

01575585

01576000

01576085

01576521

01576527

01576529

01576540

01576754

01576787

01577400

01578310

01591000

01594000

01594440

01594526

01594670

01594710
1999-2002

1994-2002

1985-2002

1996-2002

1985-1993

1985-1995

1985-1995

1993-2000

1993-2000

1985-1993

1985-1995

1985-1995

1985-2002

1985-1995

1985-1994

1993-1997

1985-1994

1985-1991

1985-1994

1985-1990

1985-1994

1987-1994

1985-1995

1993-2001

1993-2001

1993-2001

1992-1995

1985-1995

1985-1995

1986-1990

1985-2002

1986-2000

1985-2000

1985-2002

1986-2000

1986-1998

1986-1997

94
149
502
92

44.9

75.4

113

6.12

3

3

2

5

$\begin{array}{lll}152 & 7,797 & 5\end{array}$

492

11,220

6,847

44.7

16.6

756

3,354

207

470

24,100

11.2

12.6

483

0.38

510

222

267

25,990

5.82

1.77

0.36

1.42

54.2

470

148

0.43

27,100

410

34.8

98.4

348

89.7

9.38

3.26
5.5 


\begin{tabular}{|c|c|c|c|c|c|c|c|c|c|}
\hline \multirow{2}{*}{$\begin{array}{l}50^{\text {th }} \text { percentile } \\
\text { suspended- } \\
\text { sediment } \\
\text { concentration } \\
(\mathrm{mg} / \mathrm{L})\end{array}$} & \multirow{2}{*}{$\begin{array}{l}90^{\text {th }} \text { percentile } \\
\text { suspended- } \\
\text { sediment } \\
\text { concentration } \\
(\mathrm{mg} / \mathrm{L})\end{array}$} & \multirow{2}{*}{$\begin{array}{l}\text { Median } \\
\text { discharge } \\
\text { of } \\
\text { population } \\
\left(\mathrm{ft}^{3} / \mathrm{s}\right)\end{array}$} & \multirow[b]{2}{*}{$\begin{array}{l}\text { Median } \\
\text { discharge } \\
\text { of sample } \\
\left(\mathbf{f t}^{3} / \mathbf{s}\right)\end{array}$} & \multirow[b]{2}{*}{$\begin{array}{l}\text { Mann- } \\
\text { Whitney- } \\
\text { Wilcoxon } \\
\text { P-value }\end{array}$} & \multirow[b]{2}{*}{ Slope } & \multicolumn{3}{|c|}{ Sediment Transport Curve } & \multirow[b]{2}{*}{$\begin{array}{l}\text { Station } \\
\text { identification } \\
\text { number }\end{array}$} \\
\hline & & & & & & Intercept & $\begin{array}{c}\text { Regression } \\
\text { coefficient } \\
\quad\left(\mathbf{R}^{2}\right)\end{array}$ & $\begin{array}{l}\text { Drainage } \\
\text { area } \\
\text { class * }\end{array}$ & \\
\hline 11 & 35 & 23 & 64 & 0 & 0.27 & 0.54 & 0.19 & $\mathrm{~F}$ & 01485500 \\
\hline 26 & 196 & 82 & 125 & 0 & 0.72 & -0.16 & 0.24 & $\mathrm{~F}$ & 01487000 \\
\hline 10 & 47 & 82 & 150 & 0 & 0.61 & -0.37 & 0.57 & $\mathrm{E}$ & 01491000 \\
\hline 15 & 143 & 6 & 7 & 0 & 0.81 & 0.46 & 0.56 & $\mathrm{H}$ & 01493112 \\
\hline 32 & 243 & 6,000 & 19,500 & 0 & 1.02 & -2.78 & 0.67 & $\mathrm{~B}$ & 01531500 \\
\hline 20 & 140 & 9,115 & 19,500 & 0 & 0.91 & -2.32 & 0.61 & $\mathrm{~A}$ & 01540500 \\
\hline 10 & 66 & 7,010 & 14,350 & 0 & 0.93 & -2.70 & 0.63 & B & 01553500 \\
\hline 8 & 96 & 32 & 27 & 0.559 & 0.49 & 0.33 & 0.40 & $\mathrm{~F}$ & 01555400 \\
\hline 3 & 8 & 9 & 13 & 0.692 & 0.22 & 0.33 & 0.15 & G & 01559795 \\
\hline 8 & 34.5 & 410 & 400 & 0.197 & 0.75 & -1.00 & 0.43 & $\mathrm{C}$ & 01562000 \\
\hline 34 & 136 & 2,380 & 4,840 & 0 & 0.99 & -2.28 & 0.61 & B & 01567000 \\
\hline 24 & 210 & 143 & 309 & 0 & 0.83 & -0.78 & 0.56 & $\mathrm{D}$ & 01568000 \\
\hline 8 & 164 & 327 & 450 & 0.001 & 0.95 & -1.53 & 0.66 & $\mathrm{C}$ & 01570000 \\
\hline 25 & 138 & 21,000 & 39,700 & 0 & 0.95 & -2.95 & 0.68 & A & 01570500 \\
\hline 186 & 1,370 & 6 & 12 & 0 & 0.88 & 0.55 & 0.61 & G & 01571000 \\
\hline 74 & 166 & 12 & 14 & 0.080 & 0.60 & 0.99 & 0.21 & $\mathrm{G}$ & 01571490 \\
\hline 39 & 450 & 433 & 970 & 0 & 1.16 & -1.85 & 0.68 & $\mathrm{C}$ & 01573560 \\
\hline 105 & 617 & 0.03 & 1 & 0 & 0.29 & 1.92 & 0.16 & $\mathrm{H}$ & 01573810 \\
\hline 63 & 397 & 286 & 777 & 0 & 0.73 & -0.36 & 0.47 & $\mathrm{C}$ & 01574000 \\
\hline 40 & 557 & 129 & 197 & 0 & 1.13 & -1.07 & 0.63 & $\mathrm{D}$ & 01575500 \\
\hline 189 & 733 & 193 & 329 & 0 & 1.18 & -1.16 & 0.64 & $\mathrm{D}$ & 01575585 \\
\hline 49 & 192 & 24,600 & 63,000 & 0 & 1.00 & -3.10 & 0.70 & A & 01576000 \\
\hline 548 & 3,140 & 4 & 10 & 0 & 0.90 & 1.30 & 0.62 & $\mathrm{H}$ & 01576085 \\
\hline 74.5 & 840 & 2 & 3 & 0 & 1.09 & 1.36 & 0.32 & $\mathrm{H}$ & 01576521 \\
\hline 49.5 & 611 & 0.2 & 0.7 & 0 & 0.46 & 1.96 & 0.13 & $\mathrm{H}$ & 01576527 \\
\hline 39 & 643 & 1.1 & 1.4 & 0 & 1.04 & 1.52 & 0.36 & $\mathrm{H}$ & 01576529 \\
\hline 117 & 2,090 & 47 & 69 & 0.002 & 1.41 & -0.68 & 0.73 & $\mathrm{~F}$ & 01576540 \\
\hline 201 & 1,450 & 439 & 790 & 0 & 1.22 & -1.67 & 0.66 & $\mathrm{C}$ & 01576754 \\
\hline 184 & 2,070 & 138 & 204 & 0.012 & 1.52 & -1.52 & 0.48 & $\mathrm{E}$ & 01576787 \\
\hline 172.5 & 2,365 & 0.3 & 0.4 & 0 & 1.02 & 2.08 & 0.43 & $\mathrm{H}$ & 01577400 \\
\hline 16 & 85 & 25,200 & 58,300 & 0 & 0.63 & -1.77 & 0.55 & A & 01578310 \\
\hline 24 & 496 & 26 & 85 & 0 & 0.82 & -0.21 & 0.42 & G & 01591000 \\
\hline 167.5 & 904 & 75 & 262 & 0 & 1.53 & -1.92 & 0.81 & $\mathrm{E}$ & 01594000 \\
\hline 42.5 & 217 & 222 & 444 & 0 & 0.72 & -0.30 & 0.40 & $\mathrm{D}$ & 01594440 \\
\hline 161 & 582 & 52 & 309 & 0 & 0.92 & -0.20 & 0.67 & $\mathrm{~F}$ & 01594526 \\
\hline 23 & 85 & 7 & 33 & 0 & 0.43 & 0.69 & 0.34 & $\mathrm{G}$ & 01594670 \\
\hline 267 & 1,520 & 3 & 15 & 0 & 1.19 & 0.74 & 0.68 & $\mathrm{H}$ & 01594710 \\
\hline
\end{tabular}


Table 7. Summary of instantaneous suspended-sediment concentration data for stations used in this report for water years 1985 through 2002, including $10^{\text {th }}, 50^{\text {th }}$, and $90^{\text {th }}$ percentilesContinued

\begin{tabular}{|c|c|c|c|c|c|}
\hline Station name & $\begin{array}{l}\text { Station } \\
\text { identification } \\
\text { number }\end{array}$ & $\begin{array}{l}\text { Years } \\
\text { of } \\
\text { record }\end{array}$ & $\begin{array}{l}\text { Number } \\
\text { of } \\
\text { samples }\end{array}$ & $\begin{array}{l}\text { Area } \\
\text { (square } \\
\text { miles) }\end{array}$ & $\begin{array}{l}10^{\text {th }} \text { percentile } \\
\text { suspended- } \\
\text { sediment } \\
\text { concentration } \\
(\mathrm{mg} / \mathrm{L})\end{array}$ \\
\hline \multicolumn{6}{|l|}{ Potomac River } \\
\hline Conococheague Creek at Fairview, MD & 01614500 & 1985-2001 & 397 & 494 & 7 \\
\hline Muddy Creek at Mount Clinton, VA & 01621050 & 1993-2001 & 74 & 14.2 & 4 \\
\hline South Fork Shenandoah River at Front Royal, VA & 01631000 & 1985-2001 & 120 & 1,642 & 2 \\
\hline North Fork Shenandoah River near Strasburg, VA & 01634000 & 1985-2001 & 112 & 768 & 2 \\
\hline Monocacy River at Bridgeport, MD & 01639000 & 1985-1996 & 132 & 173 & 4 \\
\hline Potomac River at Chain Bridge at Washington, D.C. & 01646580 & 1985-2002 & 177 & 11,570 & 3 \\
\hline Accotink Creek near Annandale, VA & 01654000 & 1985-2001 & 50 & 23.5 & 2 \\
\hline Cedar Run near Aden, VA & 01656100 & $\begin{array}{l}\text { 1985-1988, } \\
1996-1999\end{array}$ & 1,502 & 155 & 5 \\
\hline Cedar Run at Route 646 near Aden, VA & 01656120 & 1996-2000 & 1,854 & 175 & 6 \\
\hline South Fork Quantico Creek near Independent Hill, VA & 01658500 & 1985-2001 & 3,331 & 7.64 & 5 \\
\hline Cannon Creek near Garrisonville, VA & 01660380 & 1994-1997 & 441 & 10.2 & 18 \\
\hline Beaverdam Run near Garrisonville, VA & 01660500 & 1997-2001 & 1,194 & 12.7 & 9 \\
\hline \multicolumn{6}{|l|}{ Pamunkey River } \\
\hline Pamunkey River near Hanover, VA & 01673000 & 1985-2001 & 120 & 1,081 & 3 \\
\hline \multicolumn{6}{|l|}{ Mattaponi River } \\
\hline Mattaponi River near Beulahville, VA & 01674500 & $\begin{array}{l}\text { 1985-1988, } \\
\text { 1989-2001 }\end{array}$ & 113 & 601 & 3 \\
\hline
\end{tabular}




\begin{tabular}{|c|c|c|c|c|c|c|c|c|c|}
\hline \multirow{2}{*}{$\begin{array}{l}50^{\text {th }} \text { percentile } \\
\text { suspended- } \\
\text { sediment } \\
\text { concentration } \\
(\mathrm{mg} / \mathrm{L})\end{array}$} & \multirow{2}{*}{$\begin{array}{l}90^{\text {th }} \text { percentile } \\
\text { suspended- } \\
\text { sediment } \\
\text { concentration } \\
(\mathrm{mg} / \mathrm{L})\end{array}$} & \multirow{2}{*}{$\begin{array}{l}\text { Median } \\
\text { discharge } \\
\text { of } \\
\text { population } \\
\left(\mathrm{ft}^{3} / \mathrm{s}\right)\end{array}$} & \multirow[b]{2}{*}{$\begin{array}{l}\text { Median } \\
\text { discharge } \\
\text { of sample } \\
\left(\mathbf{f t}^{3} / \mathbf{s}\right)\end{array}$} & \multirow[b]{2}{*}{$\begin{array}{l}\text { Mann- } \\
\text { Whitney- } \\
\text { Wilcoxon } \\
\text { P-value }\end{array}$} & \multirow[b]{2}{*}{ Slope } & \multicolumn{3}{|c|}{ Sediment Transport Curve } & \multirow[b]{2}{*}{$\begin{array}{l}\text { Station } \\
\text { identificatior } \\
\text { number }\end{array}$} \\
\hline & & & & & & Intercept & $\begin{array}{c}\text { Regression } \\
\text { coefficient } \\
\left(\mathbf{R}^{2}\right)\end{array}$ & $\begin{array}{l}\text { Drainage } \\
\text { area } \\
\text { class * }\end{array}$ & \\
\hline 81 & 365 & 350 & 2,230 & 0 & 0.83 & -0.87 & 0.47 & $\mathrm{C}$ & 01614500 \\
\hline 20.5 & 165 & 5 & 5 & 0.797 & 0.81 & 0.77 & 0.35 & G & 01621050 \\
\hline 10.5 & 157 & 987 & 1,600 & 0 & 1.18 & -2.77 & 0.70 & B & 01631000 \\
\hline 13 & 215 & 315 & 789 & 0 & 1.07 & -1.91 & 0.68 & $\mathrm{C}$ & 01634000 \\
\hline 74 & 460 & 75 & 565 & 0 & 0.55 & 0.24 & 0.55 & $\mathrm{E}$ & 01639000 \\
\hline 11 & 170 & 27,700 & 41,900 & 0.802 & 0.87 & -2.11 & 0.57 & A & 01646580 \\
\hline 5 & 27 & 10 & 8 & 0.181 & 0.17 & 0.63 & 0.02 & G & 01654000 \\
\hline 16 & 86 & 69 & 171 & 0 & 0.29 & 0.66 & 0.40 & $\mathrm{E}$ & 01656100 \\
\hline 19 & 95 & 146 & 165 & 0.216 & 0.27 & 0.77 & 0.32 & $\mathrm{E}$ & 01656120 \\
\hline 18 & 160 & 4 & 6 & 0 & 0.36 & 1.05 & 0.31 & $\mathrm{H}$ & 01658500 \\
\hline 150 & 617 & 12 & 42 & 0 & 1.00 & 0.43 & 0.54 & G & 01660380 \\
\hline 25 & 82 & 5 & 7 & 0 & 0.17 & 1.27 & 0.06 & G & 01660500 \\
\hline 10 & 71.5 & 510 & 651 & 0.036 & 0.78 & -1.01 & 0.58 & B & 01673000 \\
\hline 8 & 27 & 315 & 425 & 0.050 & 0.46 & -0.24 & 0.45 & $\mathrm{C}$ & 01674500 \\
\hline
\end{tabular}

\footnotetext{
* Class A > 25,000-70,200 km² (square kilometers)

$>$ 9,650-27,100 $\mathrm{mi}^{2}$ (square miles)

Class B $>2,500-25,000 \mathrm{~km}^{2}$

$>965-9,650 \mathrm{mi}^{2}$

Class C $>1,000-2,500 \mathrm{~km}^{2}$

$>386-965 \mathrm{mi}^{2}$

Class D $>500-1,000 \mathrm{~km}^{2}$

$>193-386 \mathrm{mi}^{2}$

Class E $>250-500 \mathrm{~km}^{2}$

$>96.5-193 \mathrm{mi}^{2}$

Class $\mathrm{F}>100-250 \mathrm{~km}^{2}$

$>38.6-96.5 \mathrm{mi}^{2}$

Class $\mathrm{G}>20-100 \mathrm{~km}^{2}$

$>7.70-38.6 \mathrm{mi}^{2}$

Class $\mathrm{H}>0.93-20 \mathrm{~km}^{2}$

$0.36-7.70 \mathrm{mi}^{2}$
} 


\section{EXPLANATION}

SUSPENDED-SEDIMENT STATION AND IDENTIFICATION NUMBER

\section{CHESAPEAKE BAY WATERSHED} BASINS

SUSQUEHANNA RIVER

WESTERN SHORE

PATUXENT RIVER

POTOMAC RIVER

RAPPAHANNOCK RIVER

YORK RIVER

JAMES RIVER

EASTERN SHORE
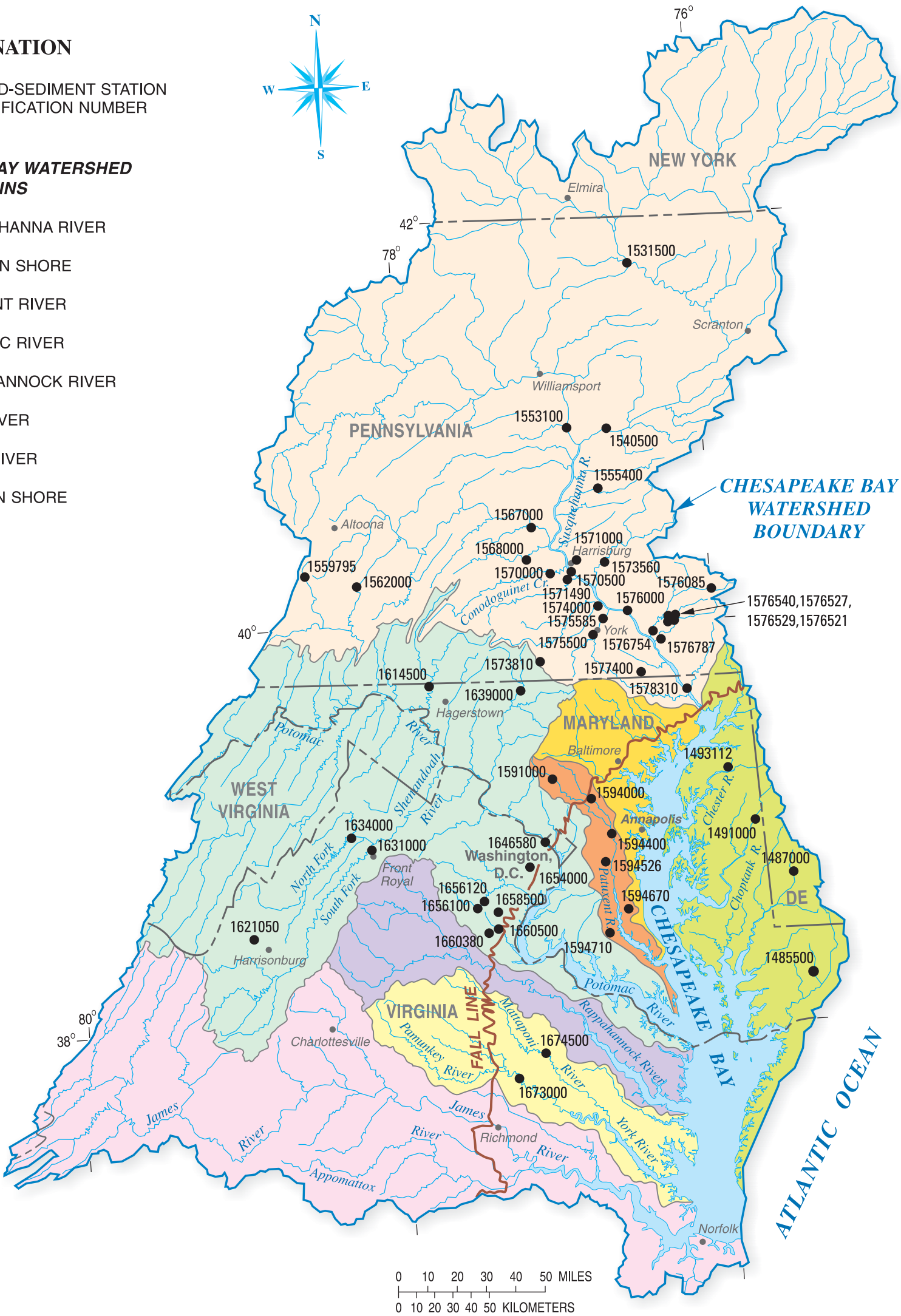

Figure 9. Location of stations in the Chesapeake Bay Watershed used in the analysis of instantaneous suspended-sediment concentration on percentiles and sediment-transport curves from 1985 through 2002. (Each station had at least 3 years of record and at least 10 suspended-sediment samples per year. Refer to table 7 for listing of stations.) 
EXPLANATION

\section{$10^{\text {th }}$ PERCENTILE OF SUSPENDED-SEDIMENT CONCENTRATION, in milligrams per liter, and STATION IDENTIFICATION NUMBER}

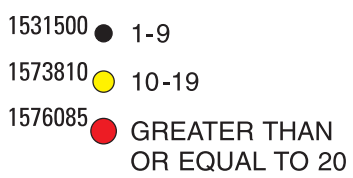

\section{CHESAPEAKE BAY WATERSHED} BASINS

SUSQUEHANNA RIVER

WESTERN SHORE

PATUXENT RIVER

POTOMAC RIVER

RAPPAHANNOCK RIVER

YORK RIVER

JAMES RIVER

EASTERN SHORE
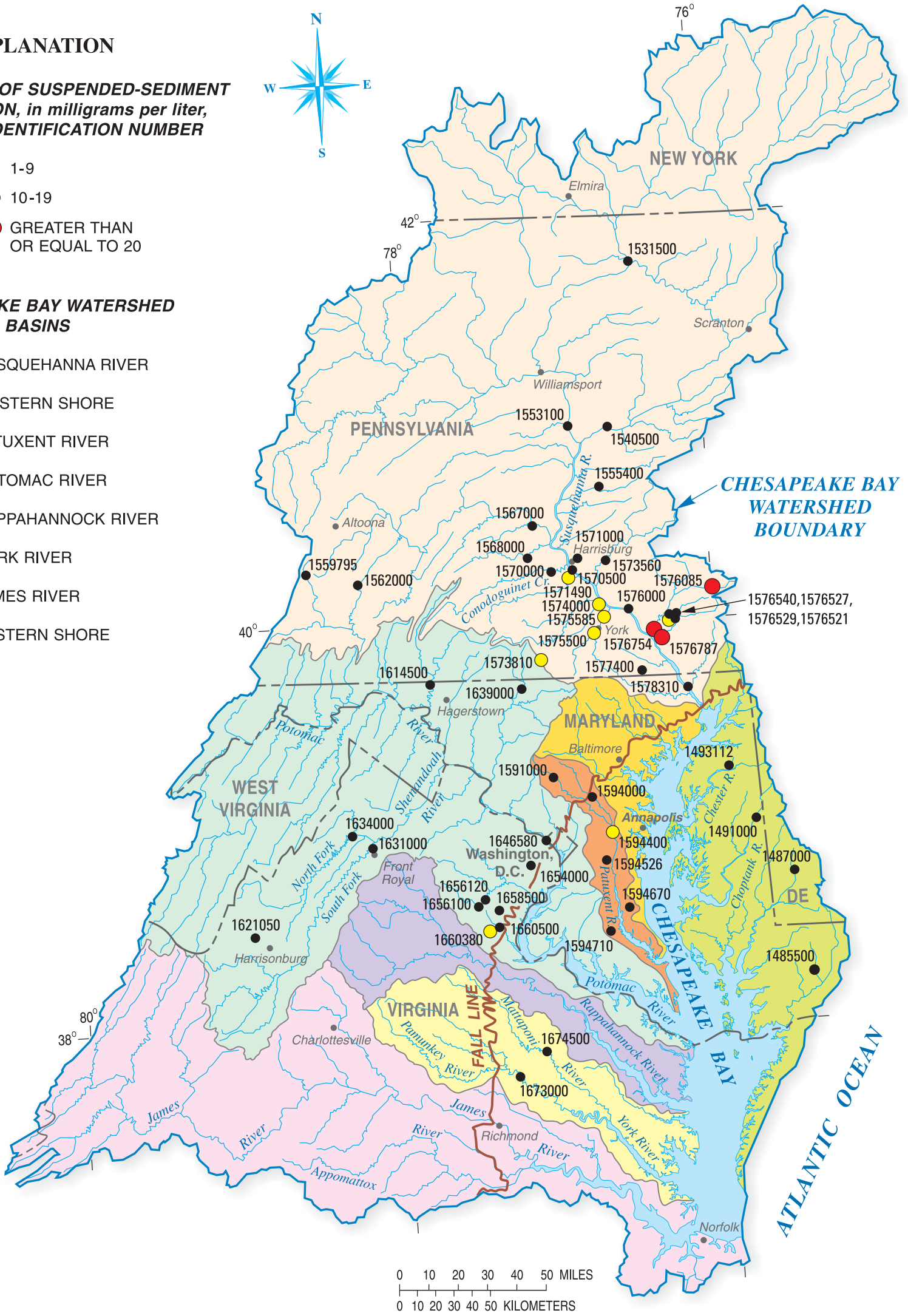

Figure 10a. The $10^{\text {th }}$ percentile of suspended-sediment concentration for 51 stations draining the Chesapeake Bay Watershed with at least 3 years of record and at least 10 samples in a given year. (Refer to table 7 for listing of stations.) 
EXPLANATION

$50^{\text {th }}$ PERCENTILE OF SUSPENDED-SEDIMENT CONCENTRATION, in milligrams per liter, and STATION IDENTIFICATION NUMBER

1531500 • $1-49$

$1614500 \bigcirc 50-99$

${ }^{1573810} \bigcirc 100-199$

$1576085 \bigcirc$ GREATER THAN OR

EQUAL TO 200

\section{CHESAPEAKE BAY WATERSHED}

BASINS

SUSQUEHANNA RIVER

WESTERN SHORE

PATUXENT RIVER

POTOMAC RIVER

RAPPAHANNOCK RIVER

YORK RIVER

JAMES RIVER

EASTERN SHORE
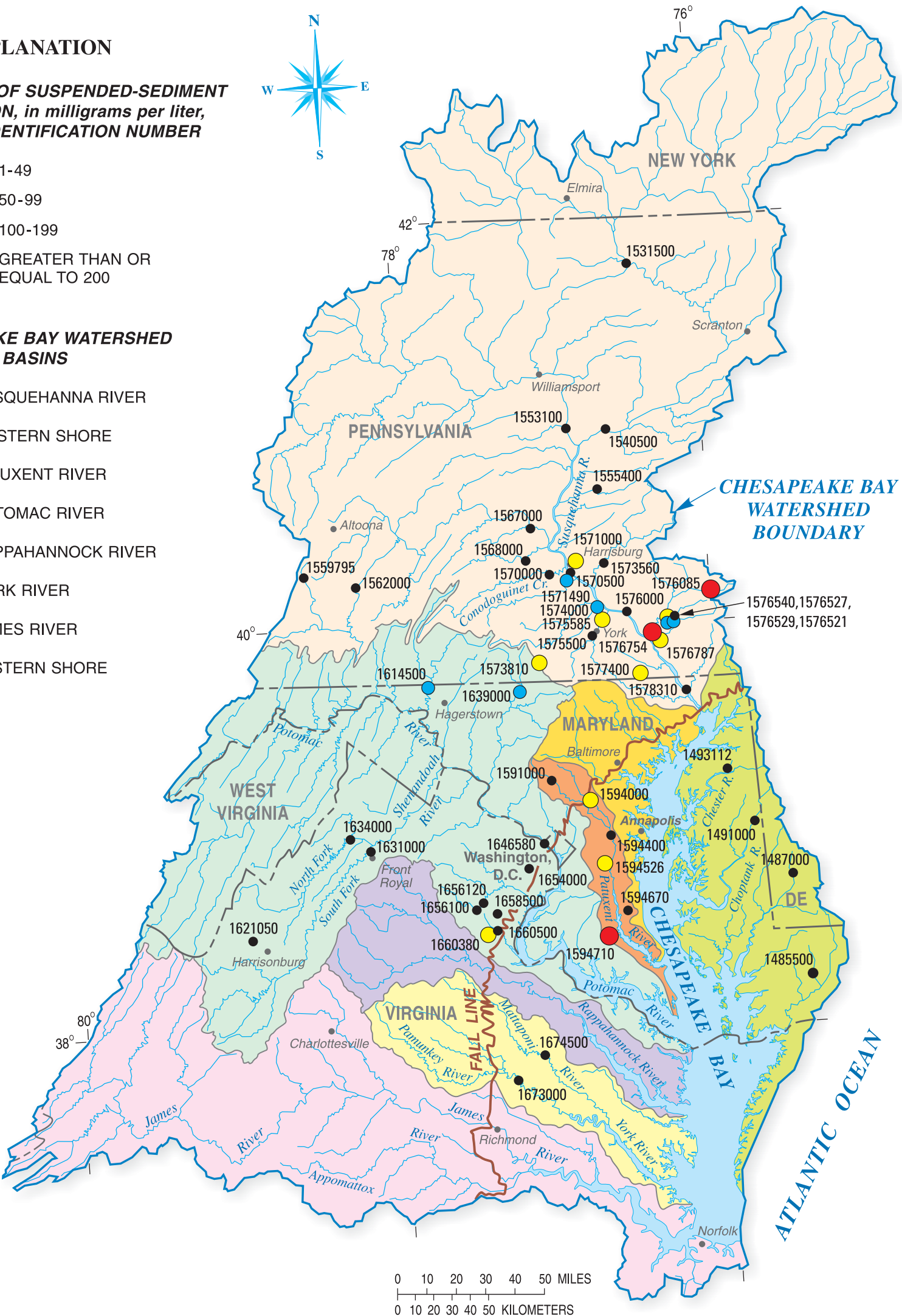

Figure 10b. The median $\left(50^{\text {th }}\right.$ percentile) of suspended-sediment concentration for 51 stations draining the Chesapeake Bay Watershed with at least 3 years of record and at least 10 samples in a given year. (Refer to table 7 for listing of stations.) 


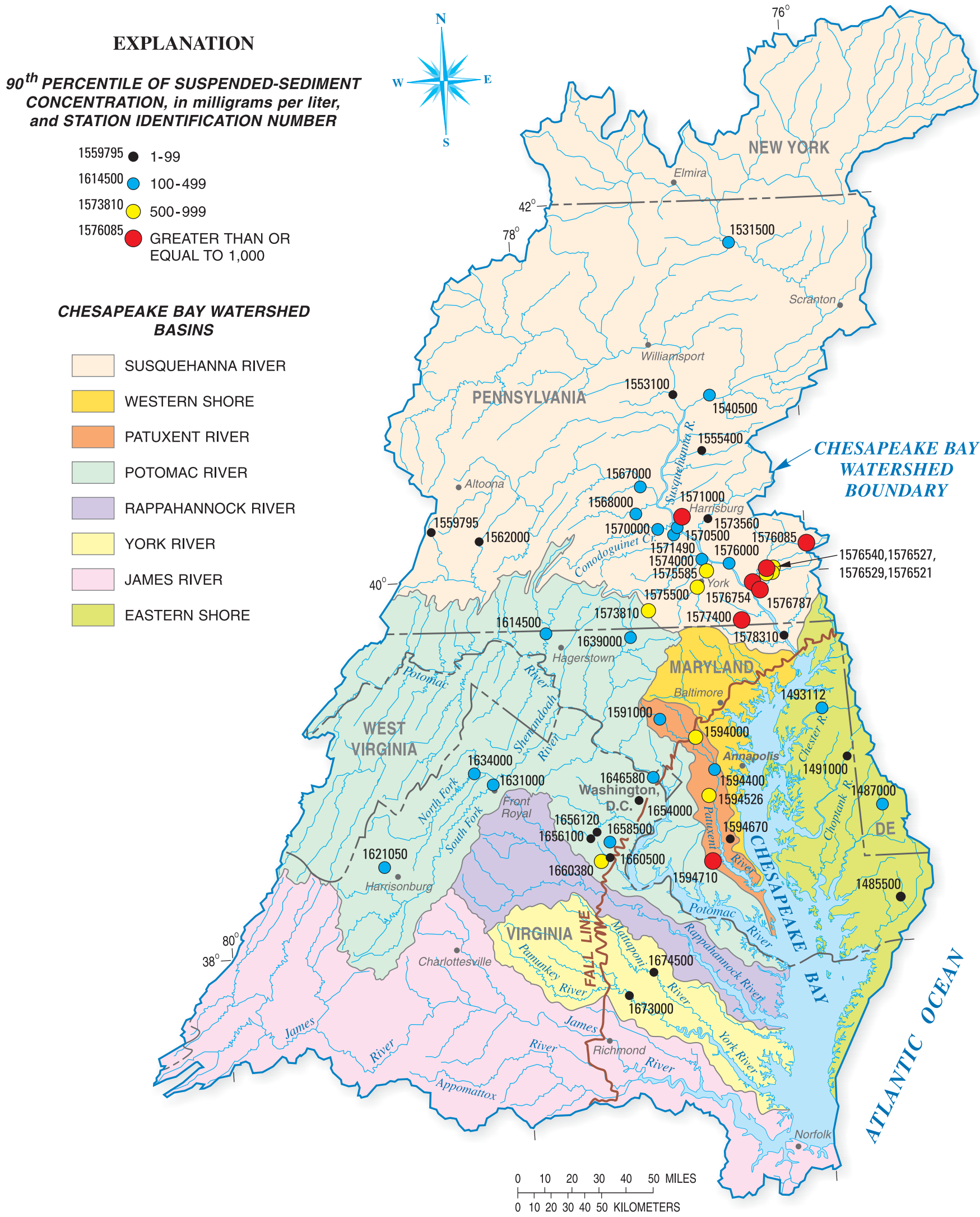

Figure 10c. The $90^{\text {th }}$ percentile of suspended-sediment concentration for 51 stations draining the Chesapeake Bay Watershed with at least 3 years of record and at least 10 samples in a given year. (Refer to table 7 for listing of stations.) 
Table 8. Rankings of $10^{\text {th }}, 50^{\text {th }}$, and $90^{\text {th }}$ percentiles of suspended-sediment concentrations from highest (1) to lowest (51) values

\begin{tabular}{|c|c|c|c|c|}
\hline Station name & $\begin{array}{l}\text { Station } \\
\text { identification } \\
\text { number }\end{array}$ & $\begin{array}{l}\text { Rank } \\
10^{\text {th }} \\
\text { percentile }\end{array}$ & $\begin{array}{l}\text { Rank } \\
\mathbf{5 0}^{\text {th }} \\
\text { percentile }\end{array}$ & $\begin{array}{l}\text { Rank } \\
90^{\text {th }} \\
\text { percentile }\end{array}$ \\
\hline Nassawango Creek near Snow Hill, MD & 01485500 & 36 & 40 & 47 \\
\hline Nanticoke River near Bridgeville, DE & 01487000 & 36 & 26 & 26 \\
\hline Choptank River near Greensboro, MD & 01491000 & 43 & 43 & 46 \\
\hline Chesterville Branch near Crumpton, MD & 01493112 & 23 & 38 & 34 \\
\hline Susquehanna River at Towanda, PA & 01531500 & 23 & 25 & 22 \\
\hline Susquehanna River at Danville, PA & 01540500 & 15 & 33 & 35 \\
\hline West Branch Susquehanna River at Lewisburg, PA & 01553500 & 43 & 43 & 45 \\
\hline East Mahantango Creek at Klingerstown, PA & 01555400 & 32 & 46 & 38 \\
\hline Bobs Creek near Pavia, PA & 01559795 & 50 & 51 & 51 \\
\hline Raystown Branch Juniata River at Saxton, PA & 01562000 & 50 & 46 & 48 \\
\hline Juniata River at Newport, PA & 01567000 & 36 & 24 & 37 \\
\hline Sherman Creek at Shermans Dale, PA & 01568000 & 23 & 29 & 25 \\
\hline Conodoguinet Creek near Hogestown, PA & 01570000 & 36 & 46 & 31 \\
\hline Susquehanna River at Harrisburg, PA & 01570500 & 23 & 27 & 36 \\
\hline Paxton Creek near Penbrook, PA & 01571000 & 19 & 5 & 7 \\
\hline Cedar Run at Eberlys Mill, PA & 01571490 & 7 & 15 & 29 \\
\hline Swatara Creek near Hershey, PA & 01573560 & 13 & 22 & 19 \\
\hline Brush Run Site 2 near McSherrystown, PA & 01573810 & 3 & 12 & 12 \\
\hline West Conewago Creek near Manchester, PA & 01574000 & 9 & 17 & 20 \\
\hline Codorus Creek near York, PA & 01575500 & 9 & 21 & 16 \\
\hline Codorus Creek at Pleasureville, PA & 01575585 & 3 & 4 & 10 \\
\hline Susquehanna River at Marietta, PA & 01576000 & 13 & 19 & 27 \\
\hline Little Conestoga Creek near Churchtown, PA & 01576085 & 1 & 1 & 1 \\
\hline Big Spring Run near Willow Street, PA & 01576521 & 15 & 14 & 9 \\
\hline North Fork Unnamed Tributary to Big Spring Run at Lampeter, PA & 01576527 & 23 & 18 & 14 \\
\hline Unnamed Tributary to Big Spring Run near Lampeter, PA & 01576529 & 32 & 22 & 11 \\
\hline Mill Creek at Eshelman Mill Road near Lyndon, PA & 01576540 & 8 & 11 & 3 \\
\hline Conestoga River at Conestoga, PA & 01576754 & 2 & 3 & 6 \\
\hline Pequea Creek at Martic Forge, PA & 01576787 & 6 & 6 & 4 \\
\hline Bald Eagle Creek near Fawn Grove, PA & 01577400 & 31 & 7 & 2 \\
\hline Susquehanna River at Conowingo, MD & 01578310 & 22 & 36 & 41 \\
\hline Patuxent River near Unity, MD & 01591000 & 43 & 29 & 17 \\
\hline Little Patuxent River at Savage, MD & 01594000 & 43 & 8 & 8 \\
\hline Patuxent River near Bowie, MD & 01594440 & 9 & 20 & 23 \\
\hline Western Branch at Upper Marlboro, MD & 01594526 & 15 & 9 & 15 \\
\hline Hunting Creek near Huntingtown, MD & 01594670 & 32 & 31 & 41 \\
\hline Killpeck Creek at Huntersville, MD & 01594710 & 19 & 2 & 5 \\
\hline Conococheague Creek at Fairview, MD & 01614500 & 15 & 13 & 21 \\
\hline Muddy Creek at Mount Clinton, VA & 01621050 & 32 & 32 & 30 \\
\hline South Fork Shenandoah River at Front Royal, VA & 01631000 & 43 & 42 & 33 \\
\hline North Fork Shenandoah River near Strasburg, VA & 01634000 & 43 & 39 & 24 \\
\hline Monocacy River at Bridgeport, MD & 01639000 & 32 & 15 & 18 \\
\hline Potomac River at Chain Bridge at Washington, D.C. & 01646580 & 36 & 40 & 28 \\
\hline Accotink Creek near Annandale, VA & 01654000 & 43 & 50 & 49 \\
\hline Cedar Run near Aden, VA & 01656100 & 23 & 36 & 40 \\
\hline Cedar Run at Route 646 near Aden, VA & 01656120 & 19 & 34 & 39 \\
\hline South Fork Quantico Creek near Independent Hill, VA & 01658500 & 23 & 35 & 32 \\
\hline Cannon Creek near Garrisonville, VA & 01660380 & 5 & 10 & 12 \\
\hline Beaverdam Run near Garrisonville, VA & 01660500 & 12 & 27 & 43 \\
\hline Pamunkey River near Hanover, VA & 01673000 & 36 & 43 & 44 \\
\hline Mattaponi River near Beulahville, VA & 01674500 & 36 & 46 & 49 \\
\hline
\end{tabular}


Eastern Shore
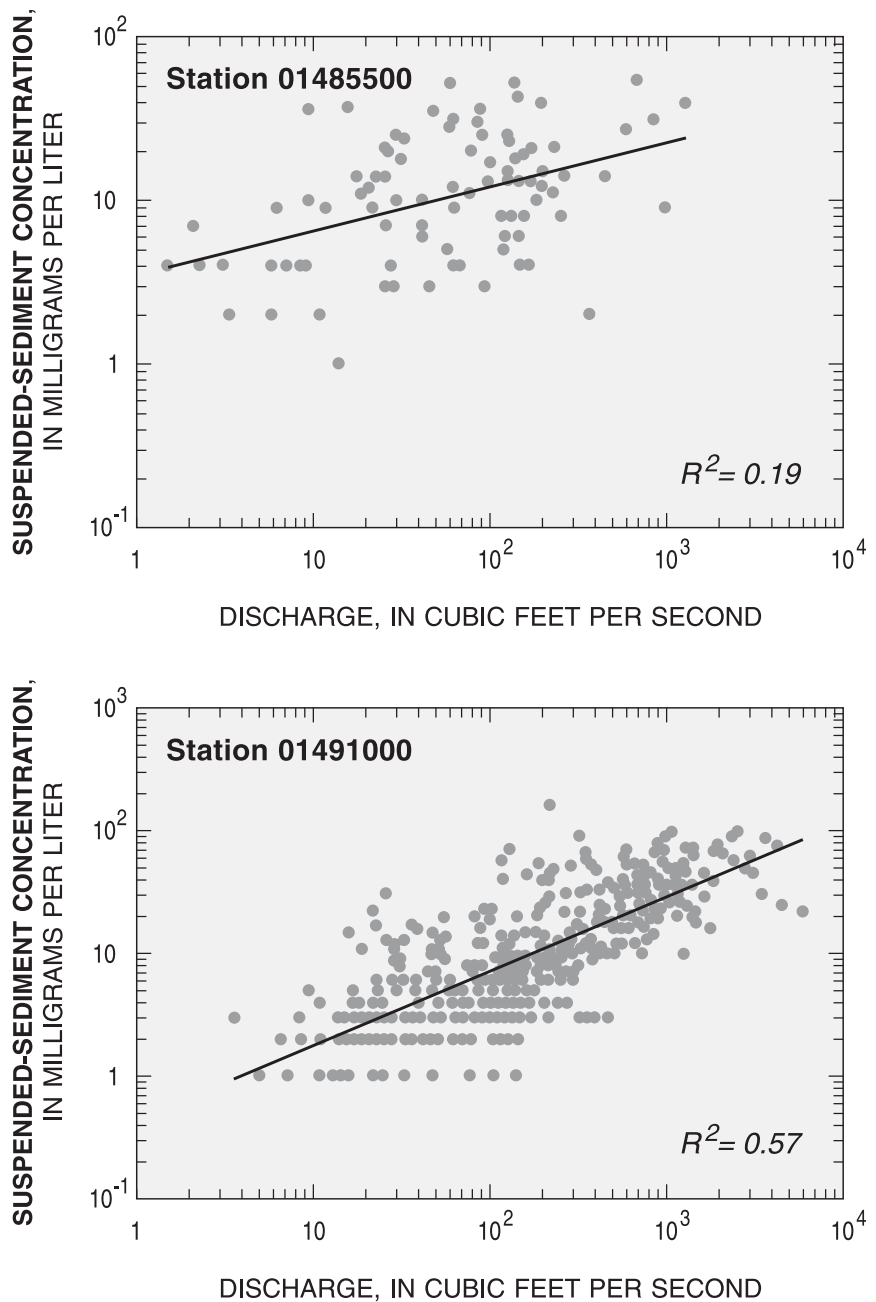
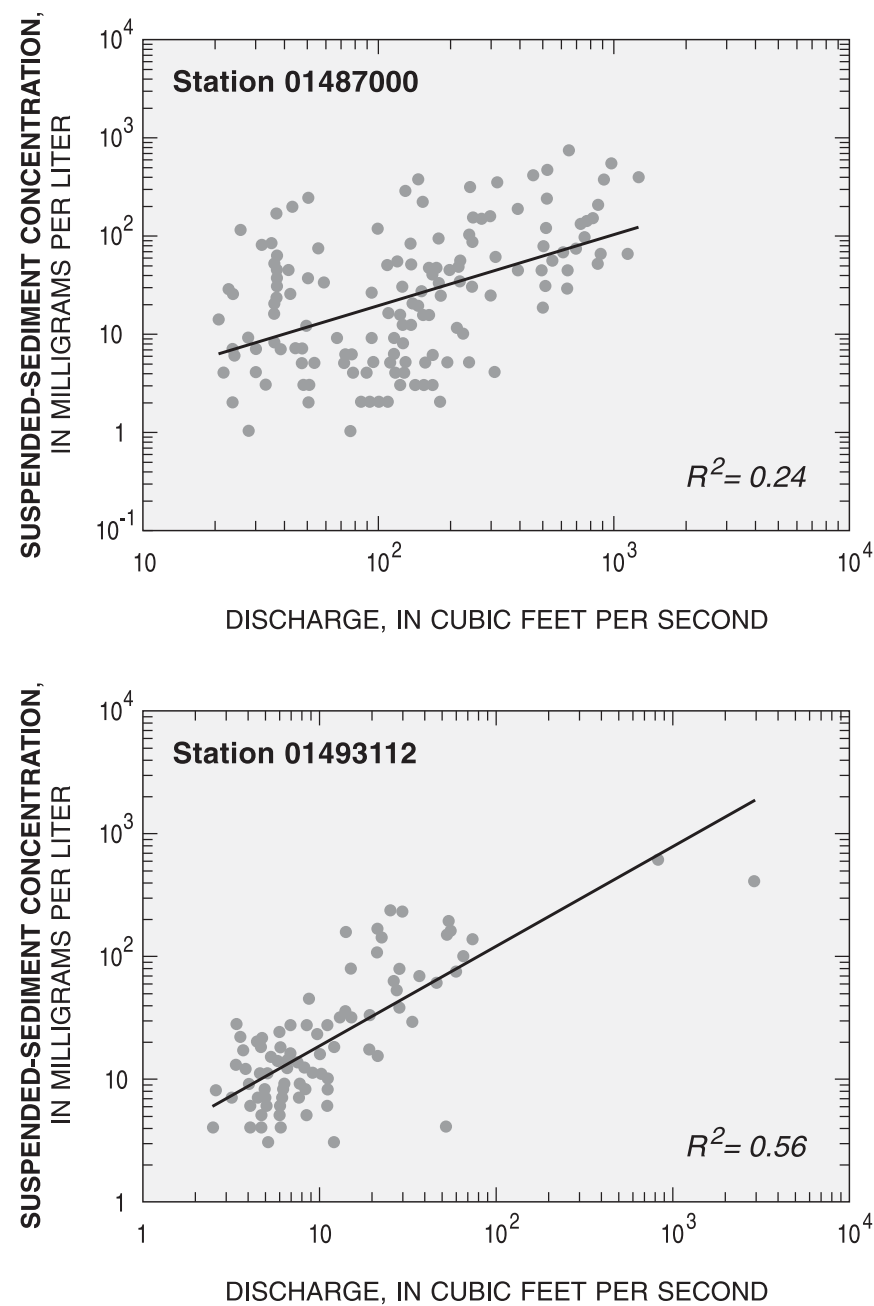

Figure 11a. Sediment-transport curves for the stream-gaging stations on the Eastern Shore of Maryland and Delaware. (Refer to table 7 for listing of stations.) 


\section{Susquehanna River}

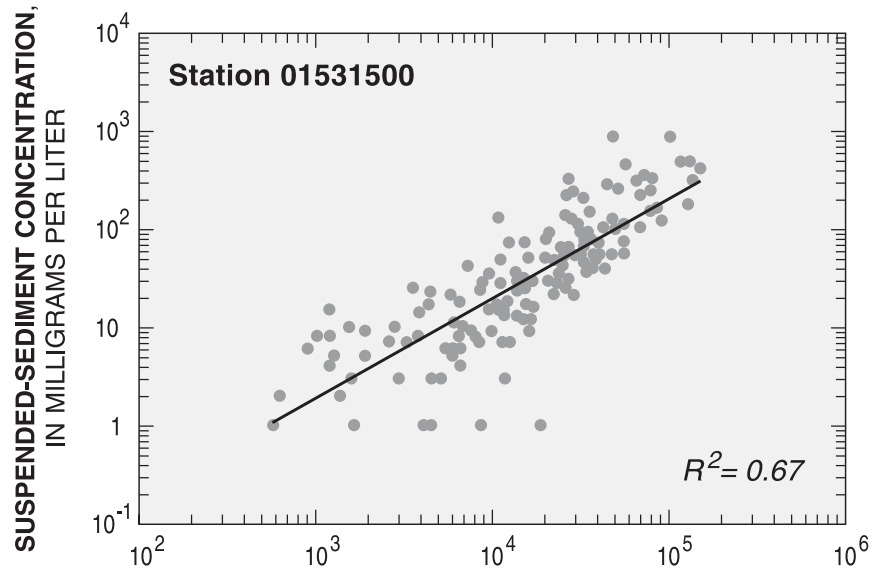

DISCHARGE, IN CUBIC FEET PER SECOND

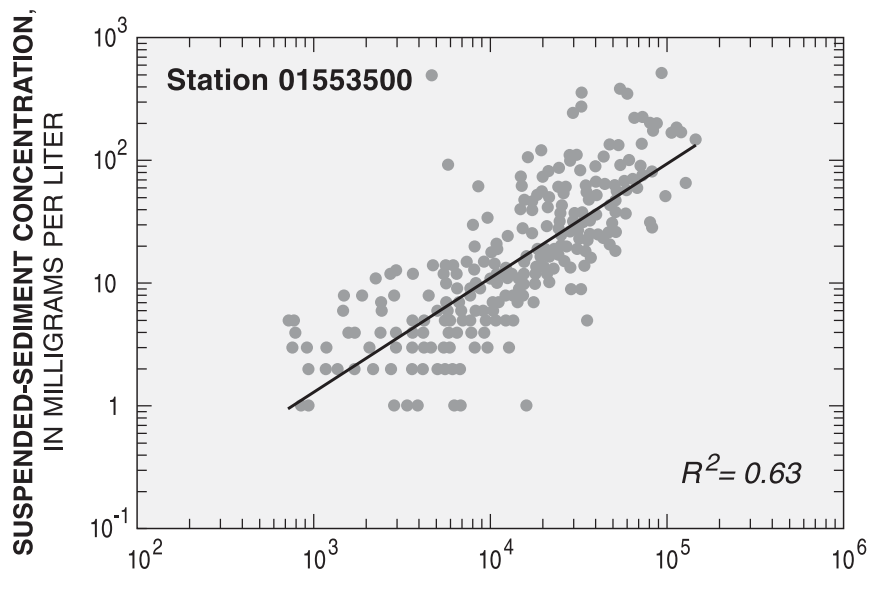

DISCHARGE, IN CUBIC FEET PER SECOND

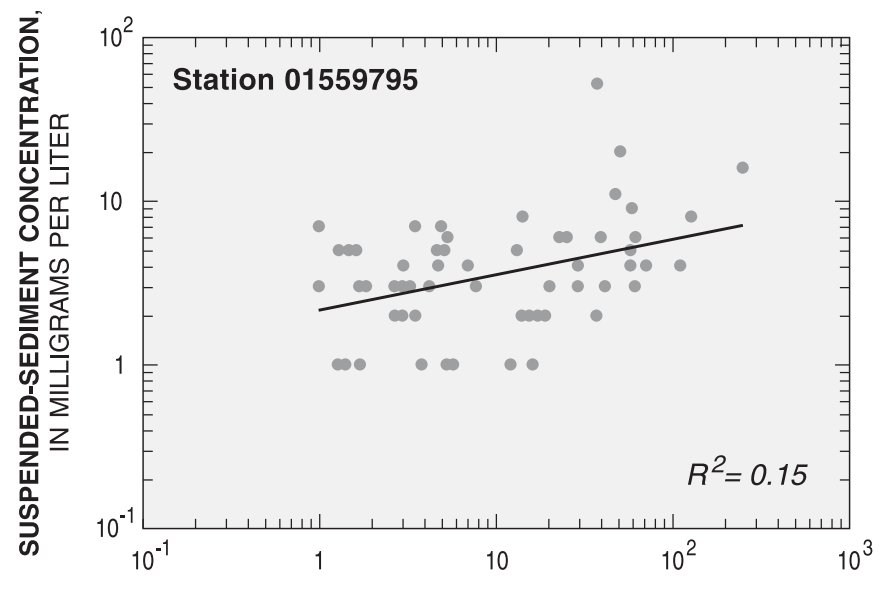

DISCHARGE, IN CUBIC FEET PER SECOND

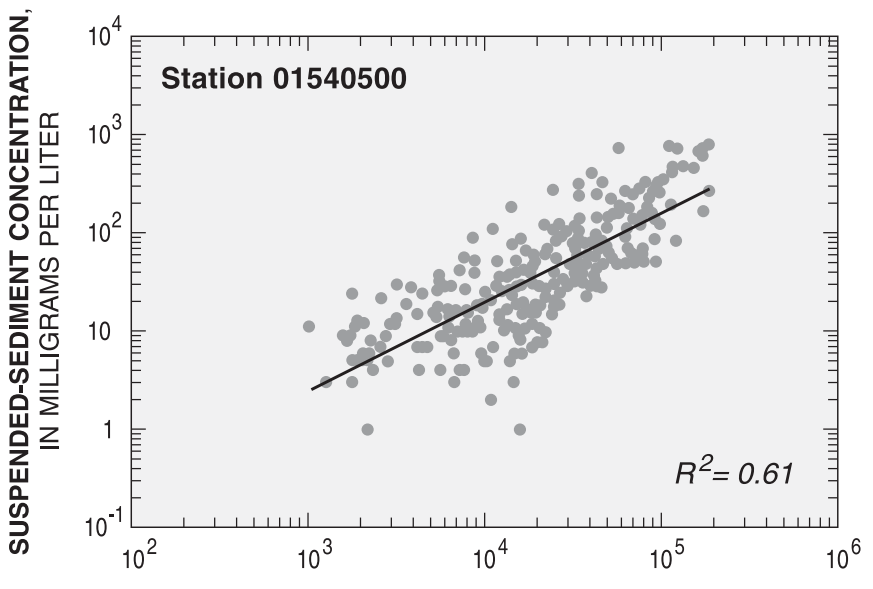

DISCHARGE, IN CUBIC FEET PER SECOND

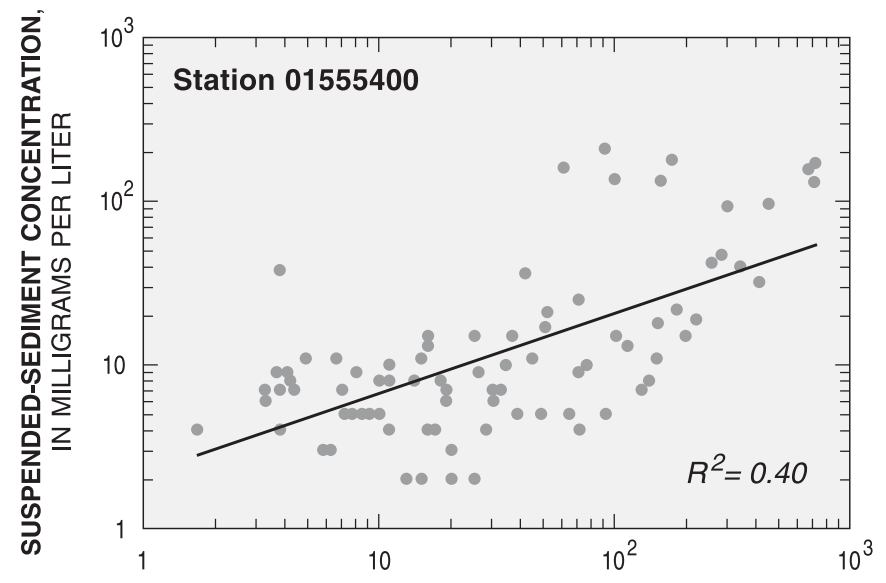

DISCHARGE, IN CUBIC FEET PER SECOND

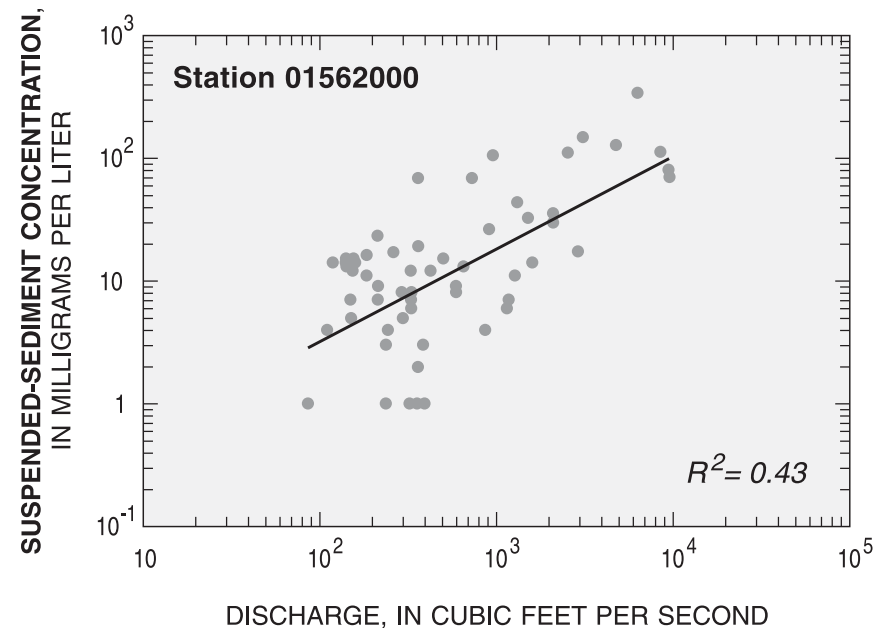

Figure 11b. Sediment-transport curves for the stream-gaging stations in the Susquehanna River Basin. (Refer to table 7 for listing of stations.) 

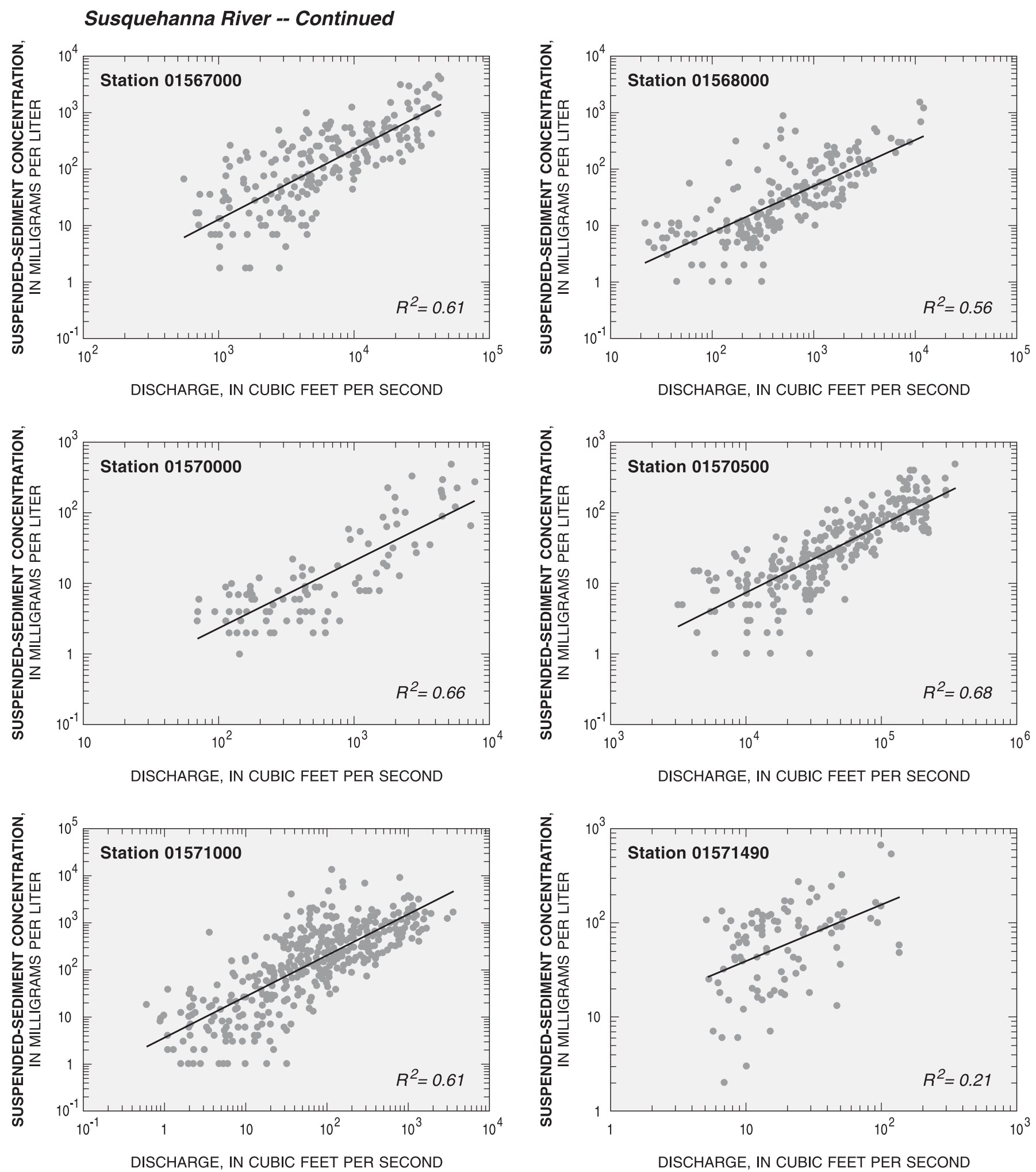

Figure 11b. Sediment-transport curves for the stream-gaging stations in the Susquehanna River Basin. -- Continued. 


\section{Susquehanna River -- Continued}
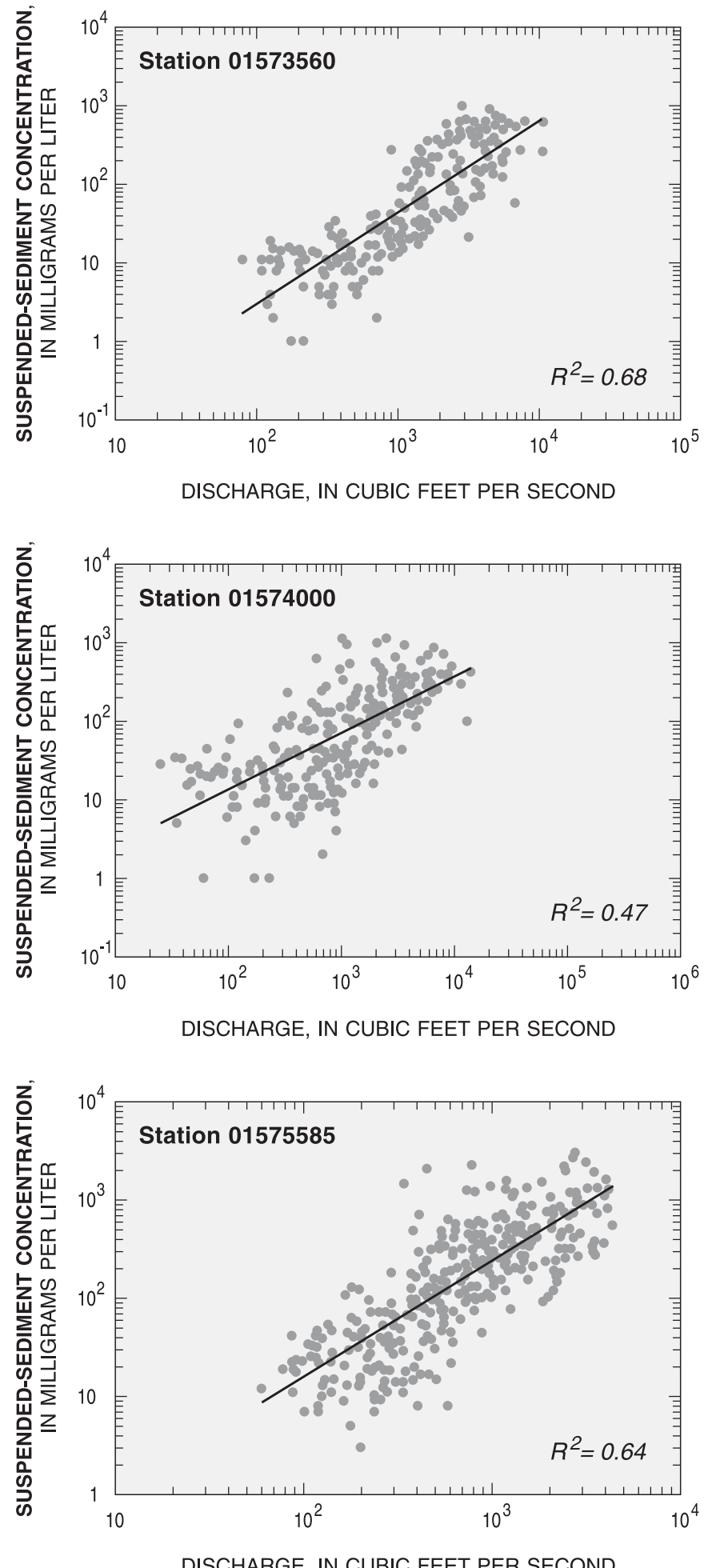
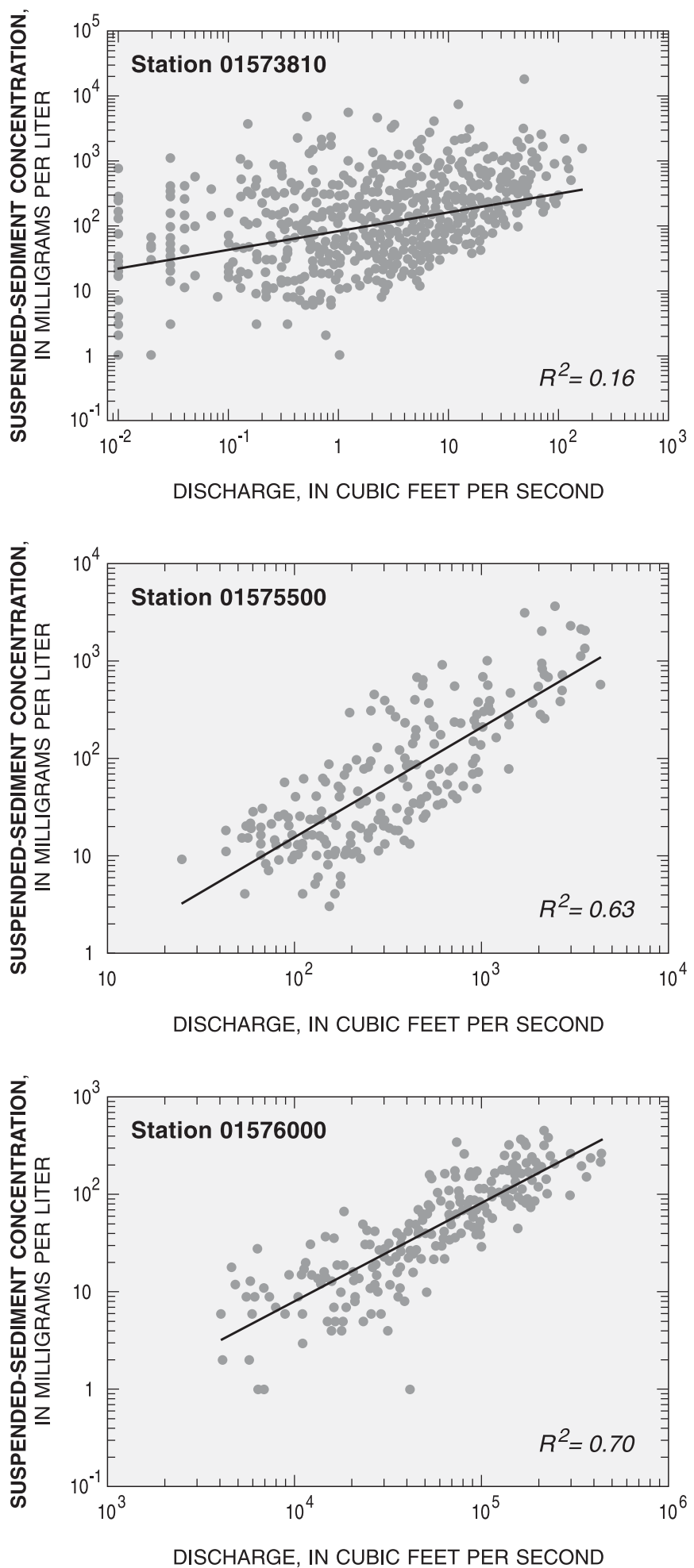

Figure 11b. Sediment-transport curves for the stream-gaging stations in the Susquehanna River Basin. -- Continued. 


\section{Susquehanna River -- Continued}
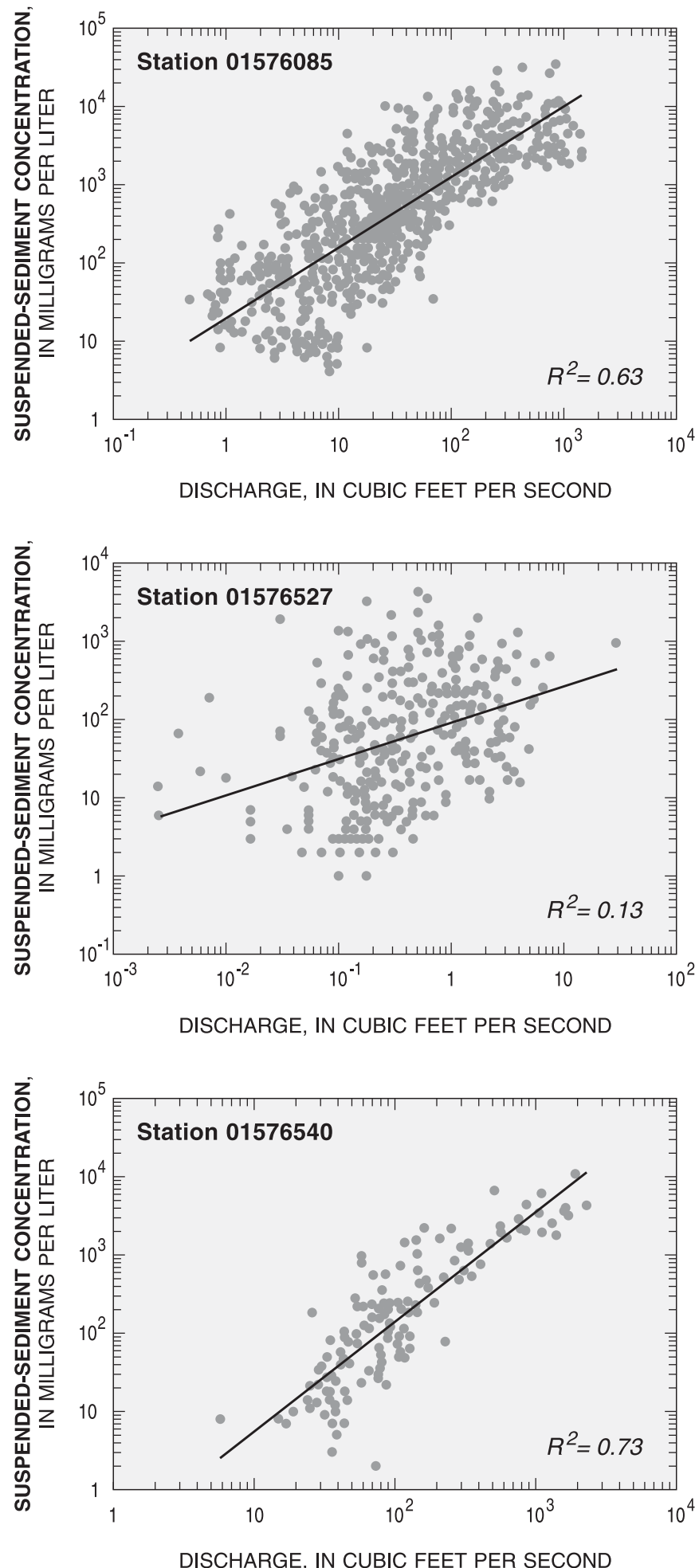
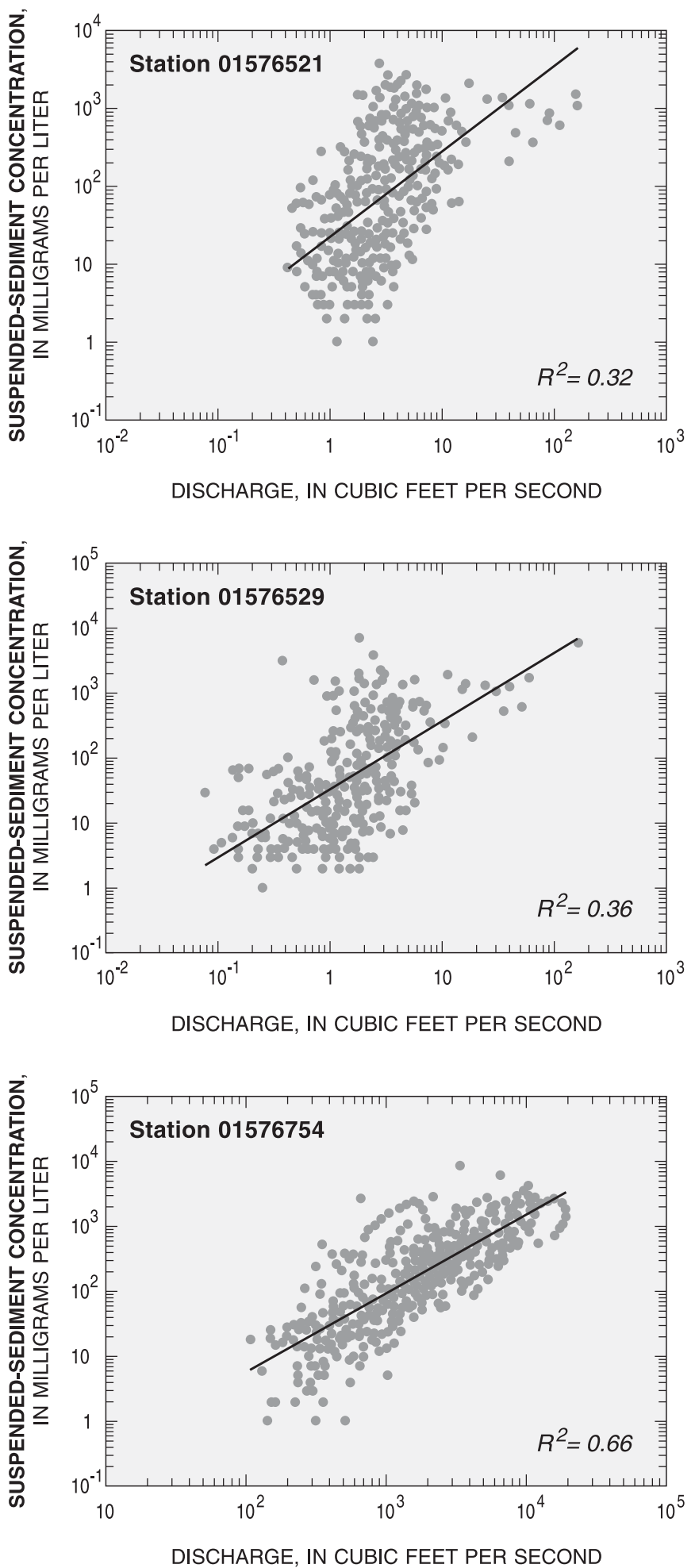

Figure 11b. Sediment-transport curves for the stream-gaging stations in the Susquehanna River Basin. -- Continued. 

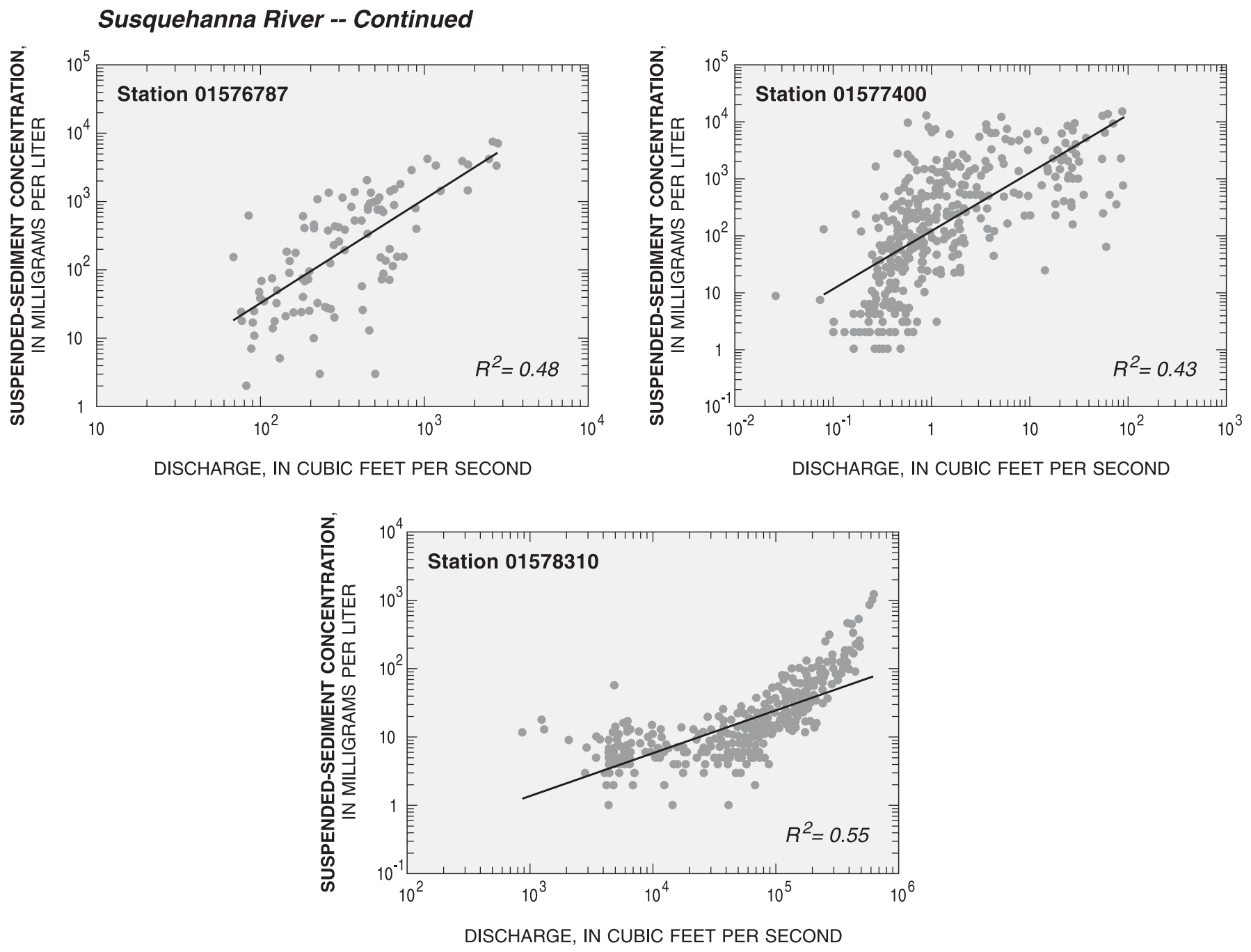

Figure 11b. Sediment-transport curves for the stream-gaging stations in the Susquehanna River Basin. -- Continued. 


\section{Patuxent River}

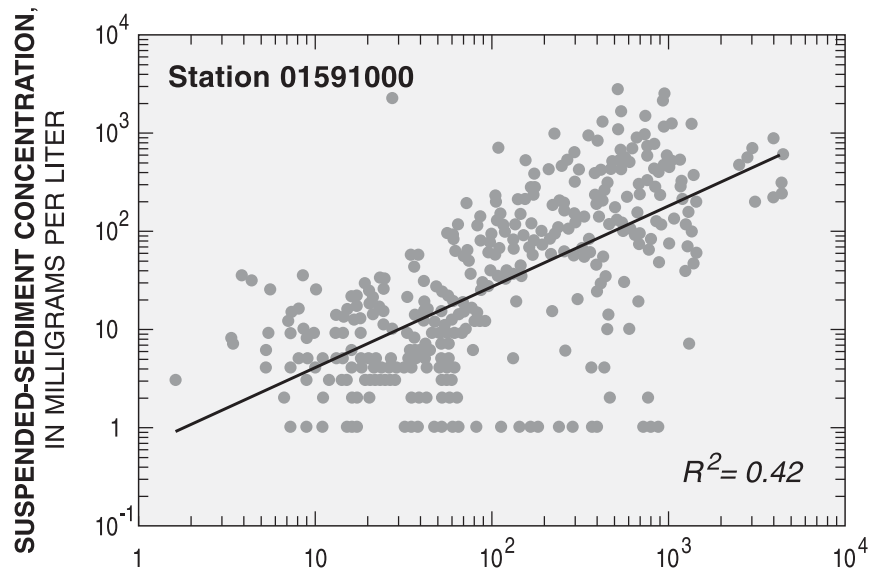

DISCHARGE, IN CUBIC FEET PER SECOND

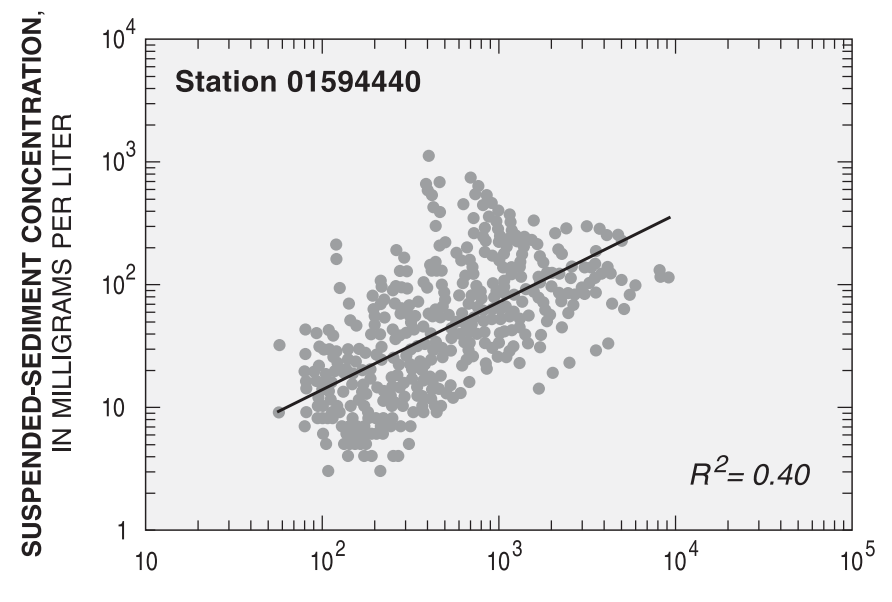

DISCHARGE, IN CUBIC FEET PER SECOND

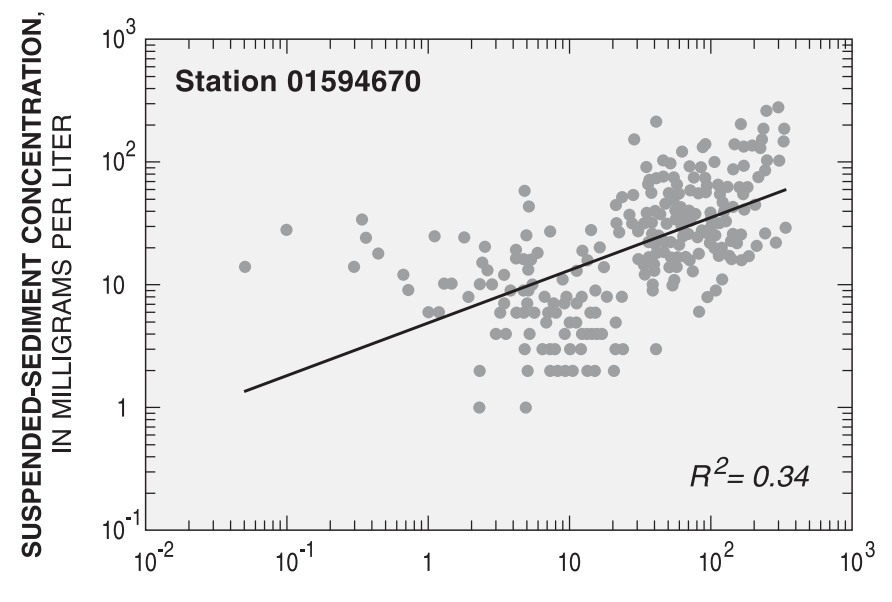

DISCHARGE, IN CUBIC FEET PER SECOND

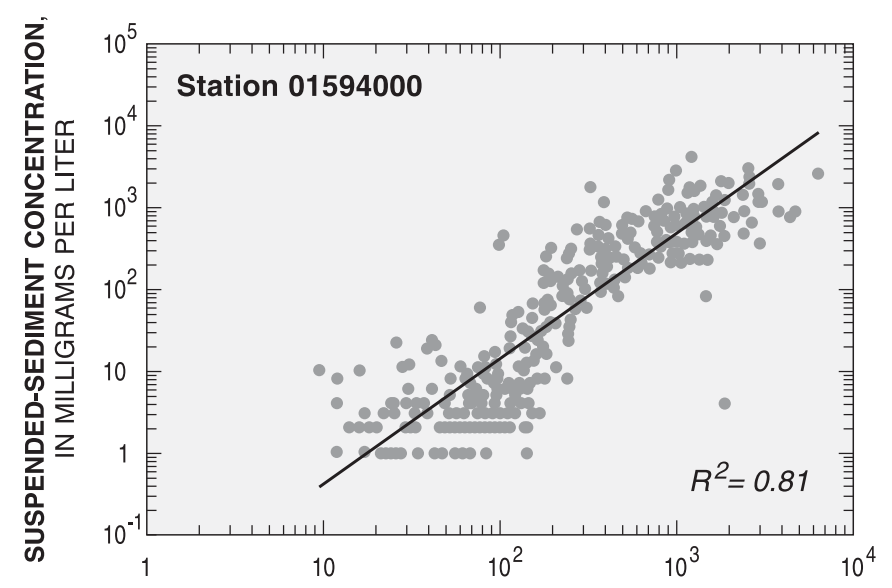

DISCHARGE, IN CUBIC FEET PER SECOND

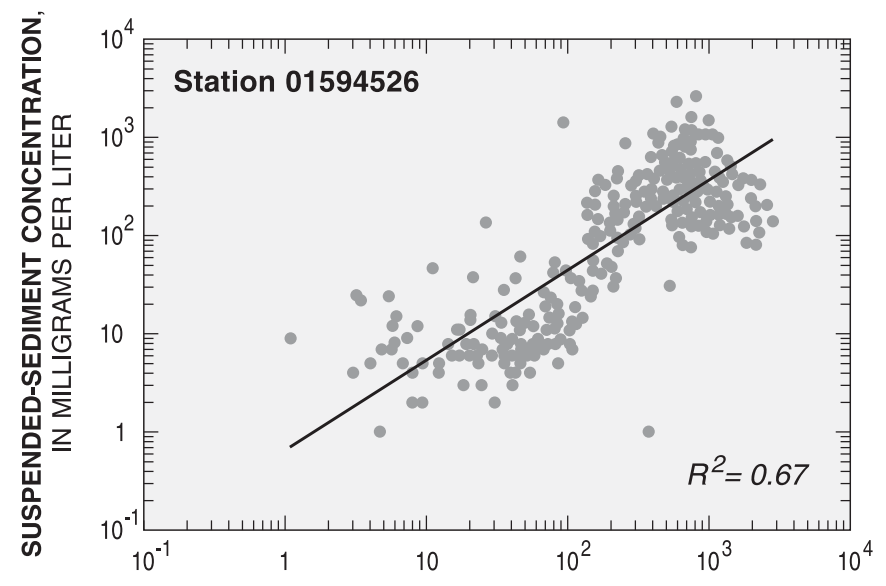

DISCHARGE, IN CUBIC FEET PER SECOND

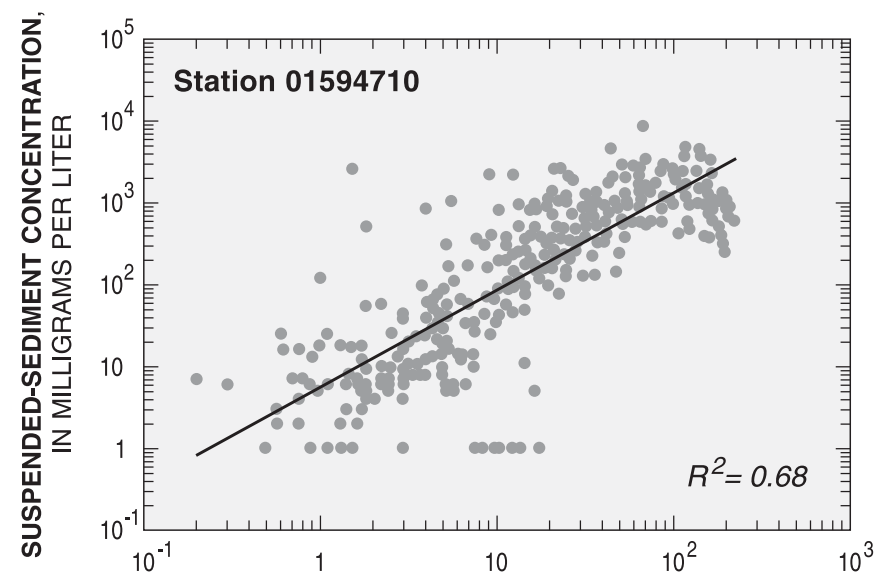

DISCHARGE, IN CUBIC FEET PER SECOND

Figure 11c. Sediment-transport curves for the stream-gaging stations in the Patuxent River Basin. (Refer to table 7 for listing of stations.) 

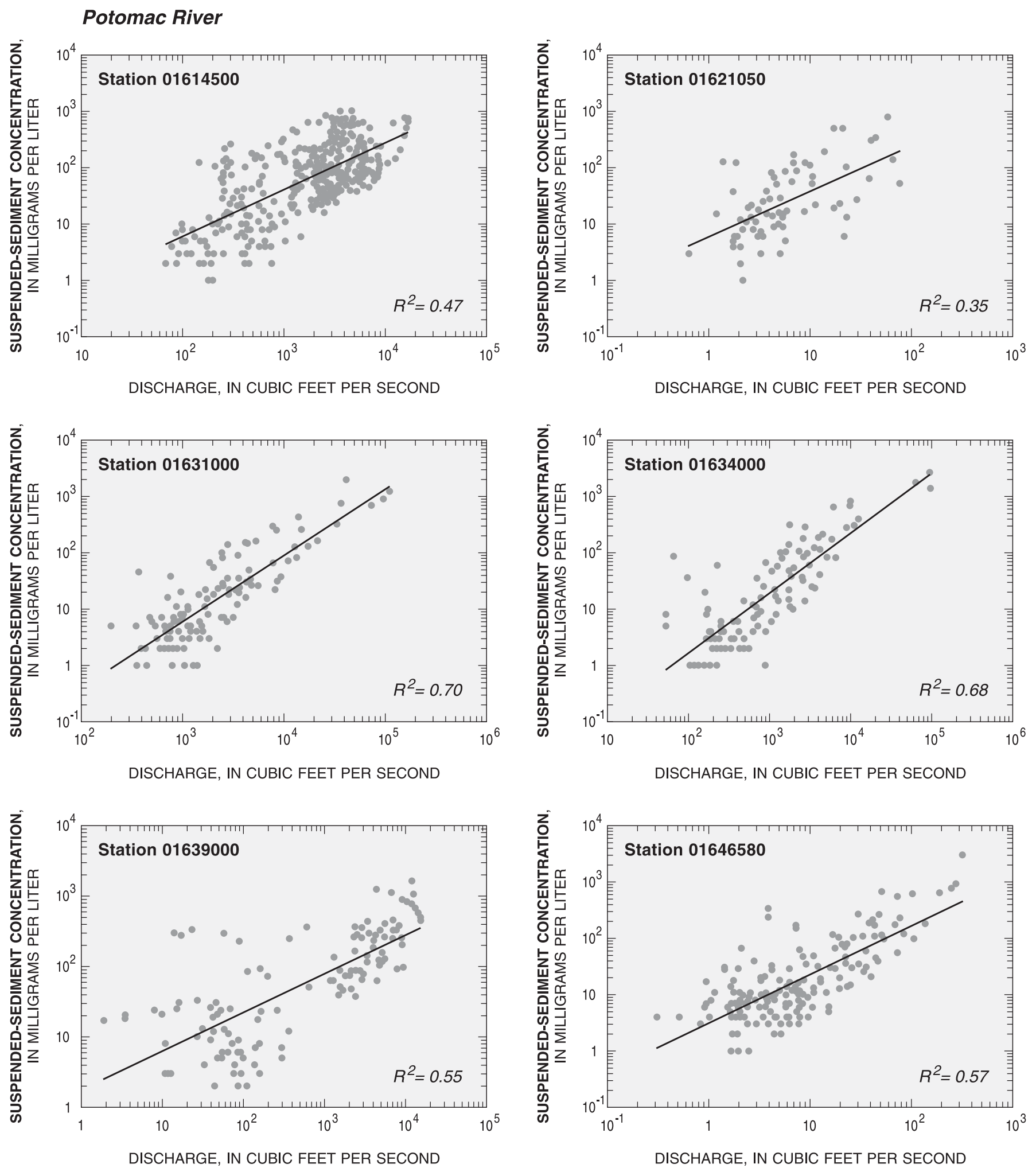

Figure 11d. Sediment-transport curves for the stream-gaging stations in the Potomac River Basin. (Refer to table 7 for listing of stations.) 


\section{Potomac River -- Continued}

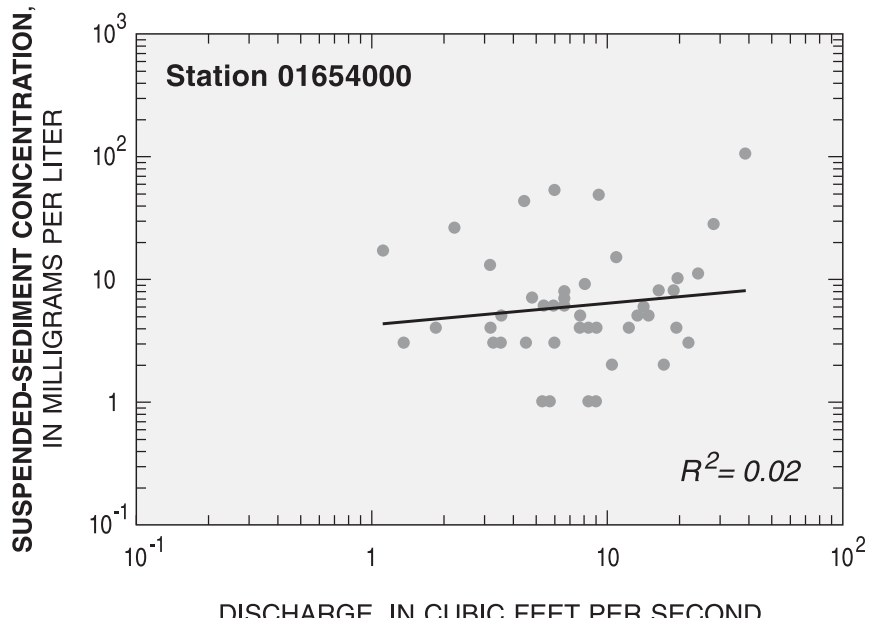

DISCHARGE, IN CUBIC FEET PER SECOND
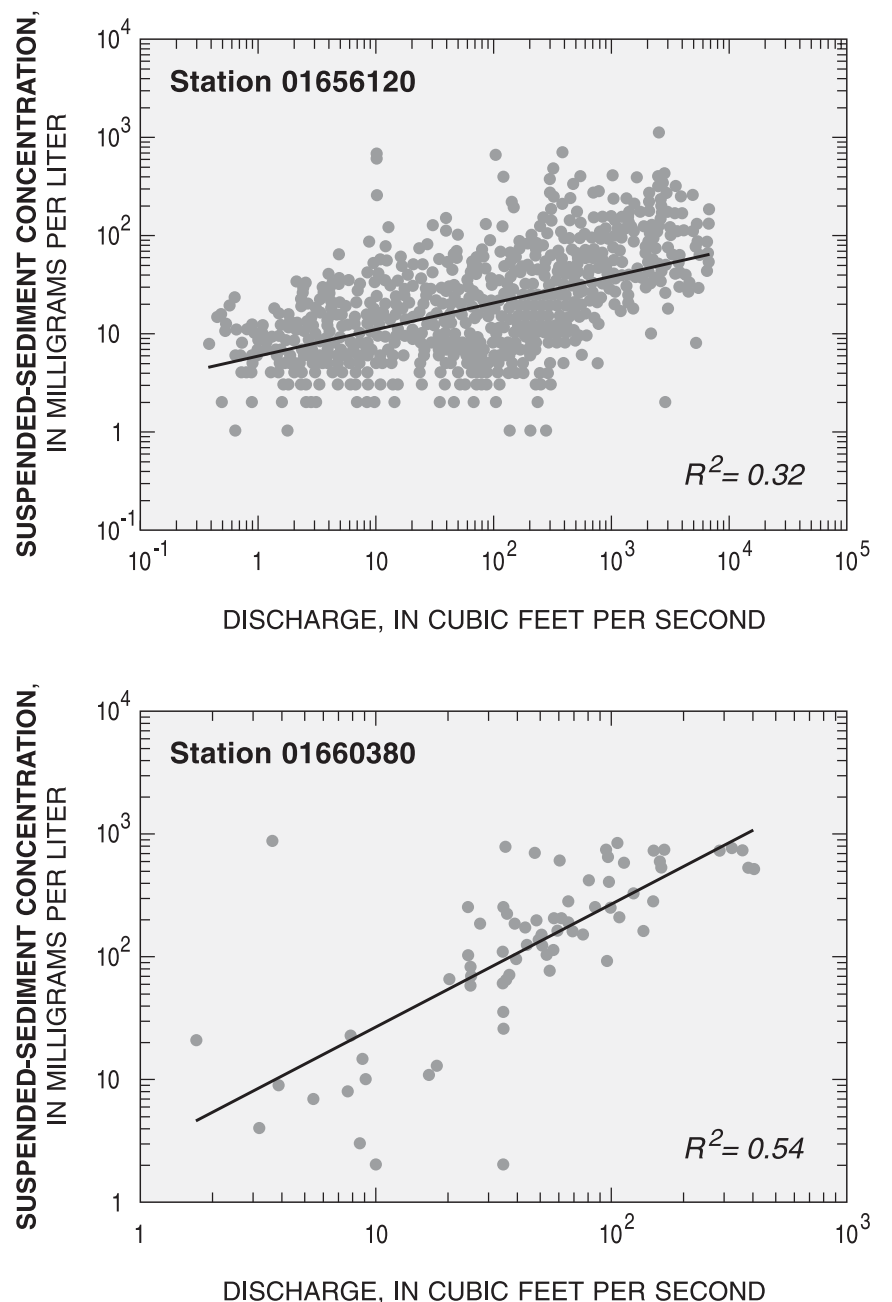
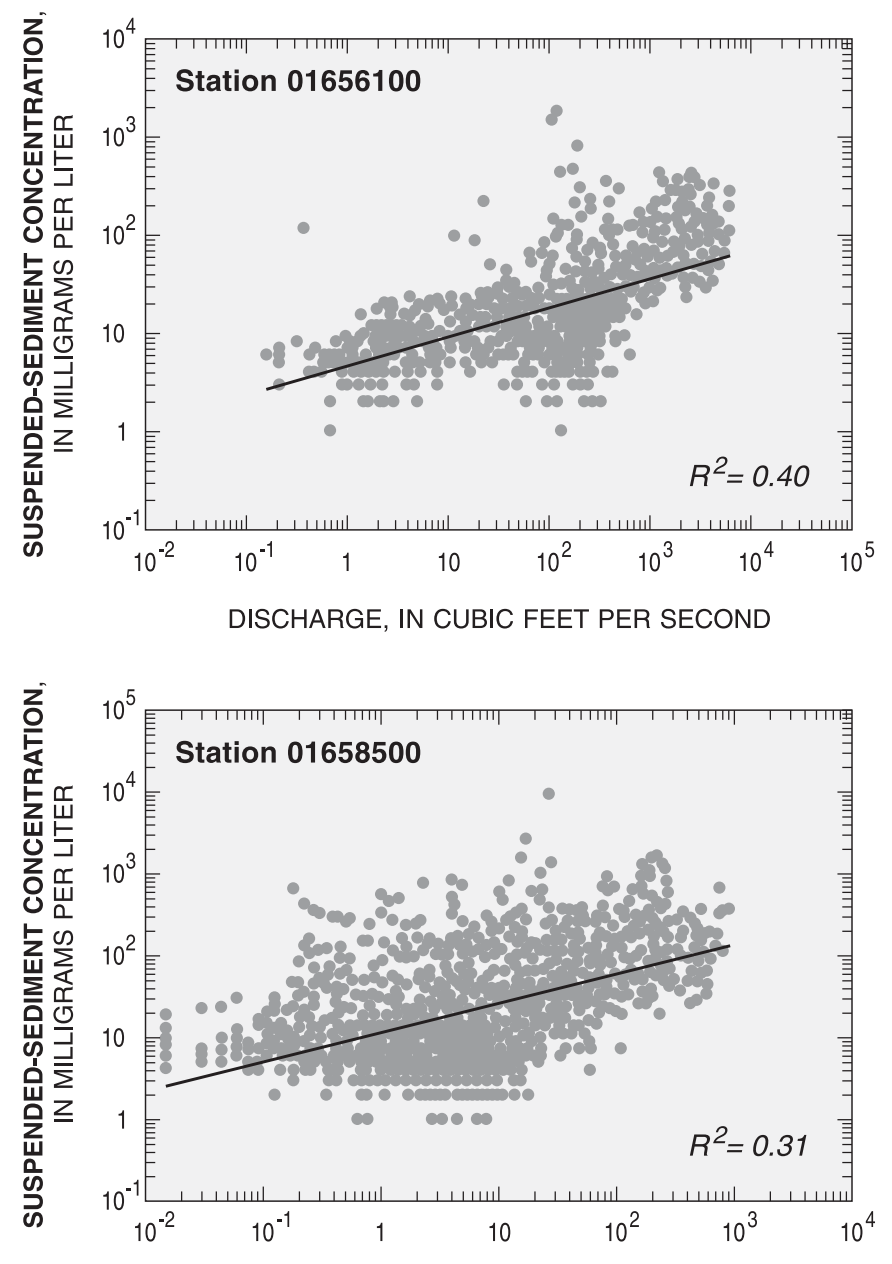

DISCHARGE, IN CUBIC FEET PER SECOND

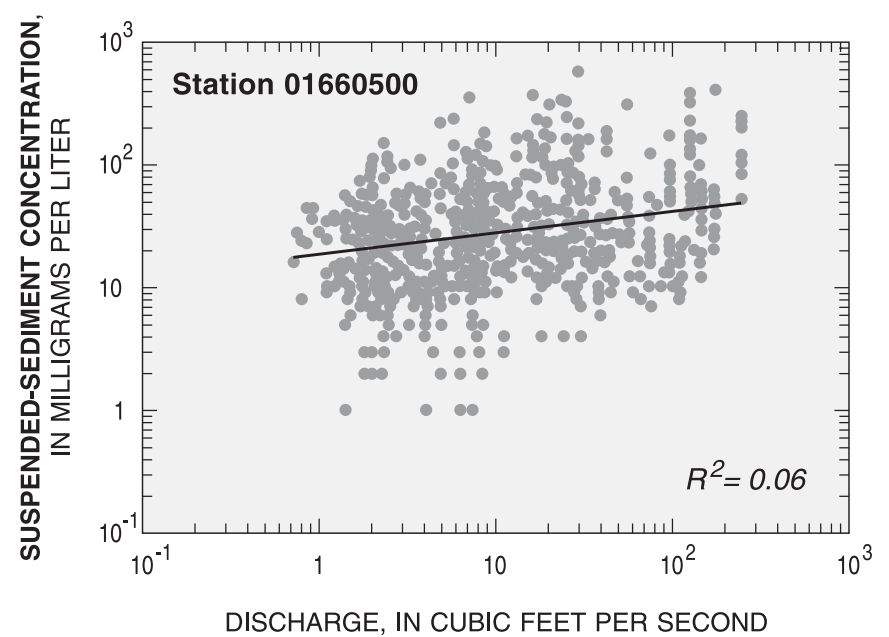

Figure 11d. Sediment-transport curves for the stream-gaging stations in the Potomac River Basin. -- Continued. 
Pamunkey River

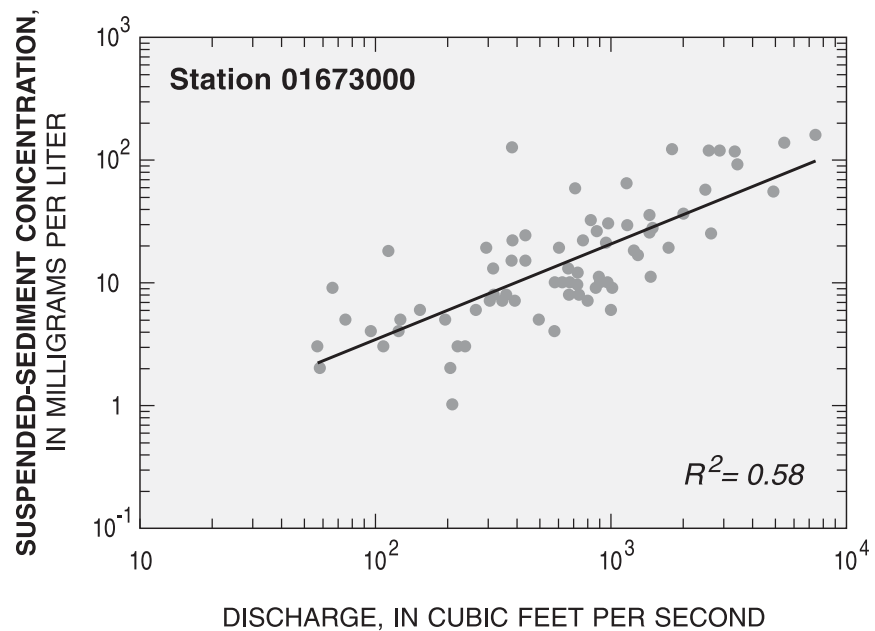

\section{Mattaponi River}

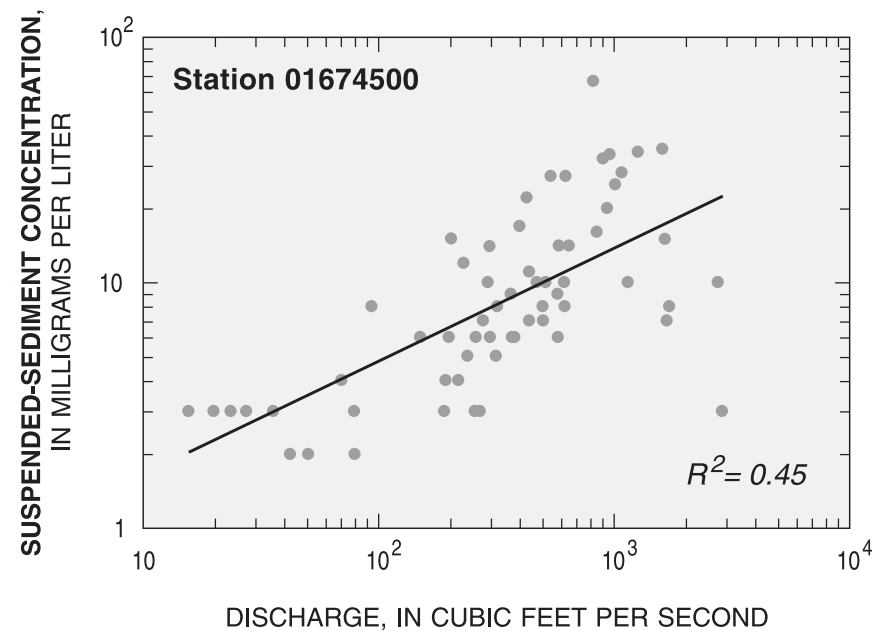

Figure 11e. Sediment-transport curves for the stream-gaging stations in the Pamunkey and Mattaponi River Basins. (Refer to table 7 for listing of stations.) 


\section{Class A}

[>9,650-27,100 square miles]

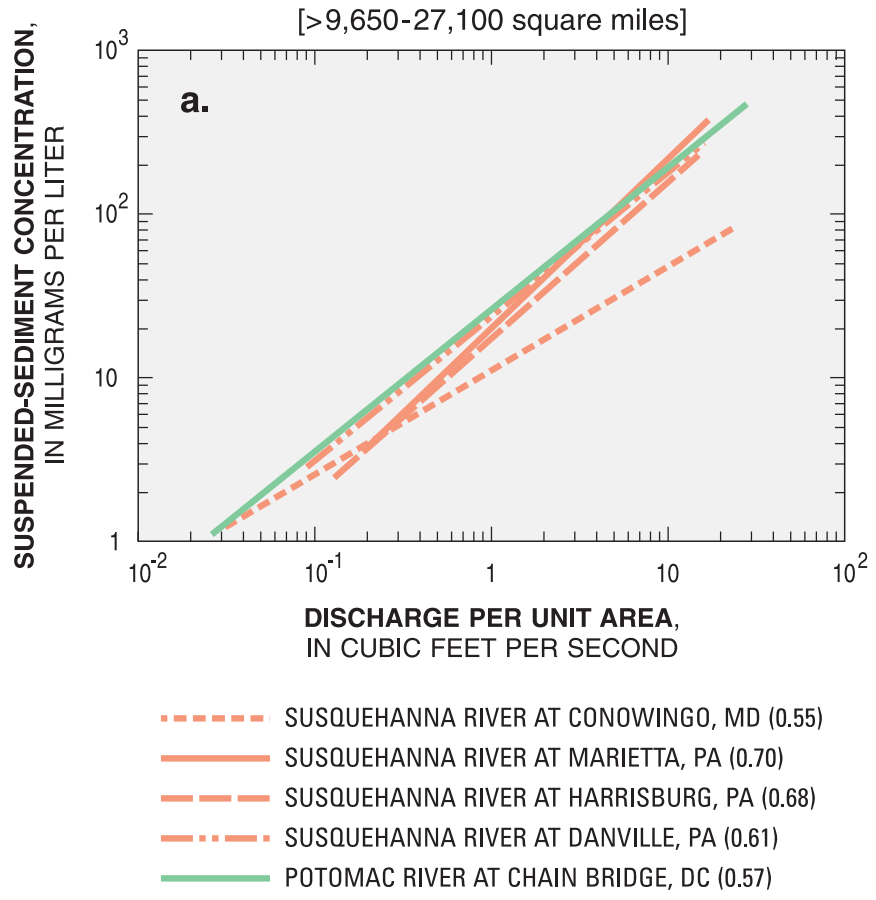

Class C

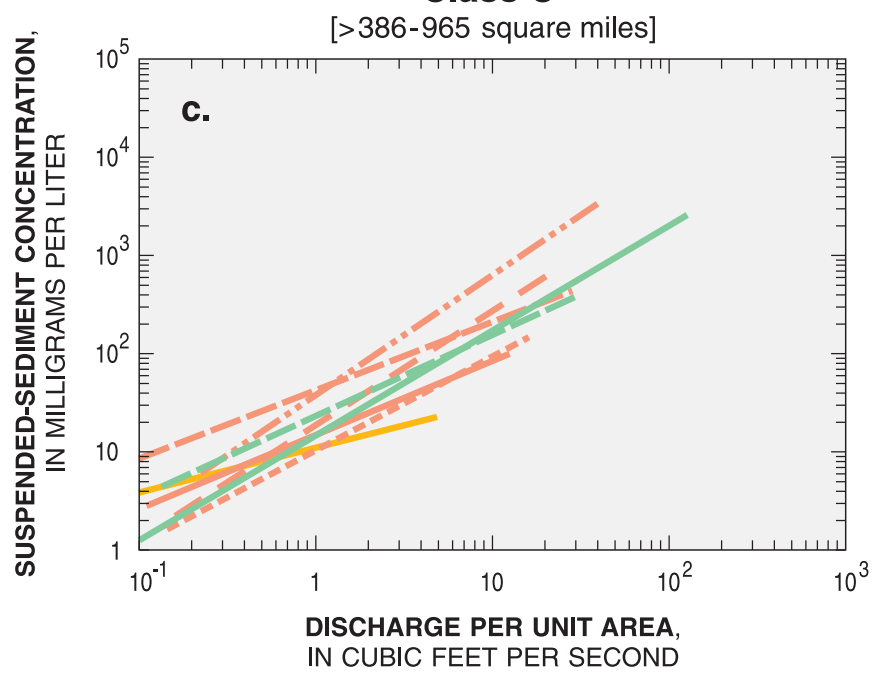

RAYSTOWN BRANCH JUNIATA RIVER AT SAXTON, PA (0.43)

- - W. CONEWAGO CREEK NEAR MANCHESTER, PA (0.47)

- - - SWATARA CREEK NEAR HERSHEY, PA (0.68)

$=-n=-=$ CONODOGUINET CREEK NEAR HOGESTOWN, PA (0.66)

$-\because-=$ CONESTOGA RIVER AT CONESTOGA, PA (0.66)

N. FORK SHENANDOAH RIVER NEAR STRASBURG, VA (0.68)

- CONOCOCHEAGUE CREEK AT FAIRVIEW, MD (0.47)

- MATTAPONI RIVER NEAR BEULAHVILLE, VA (0.45)
Class B

[>965-9,650 square miles]

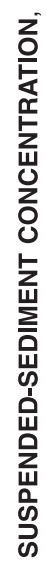

10 兰

b.

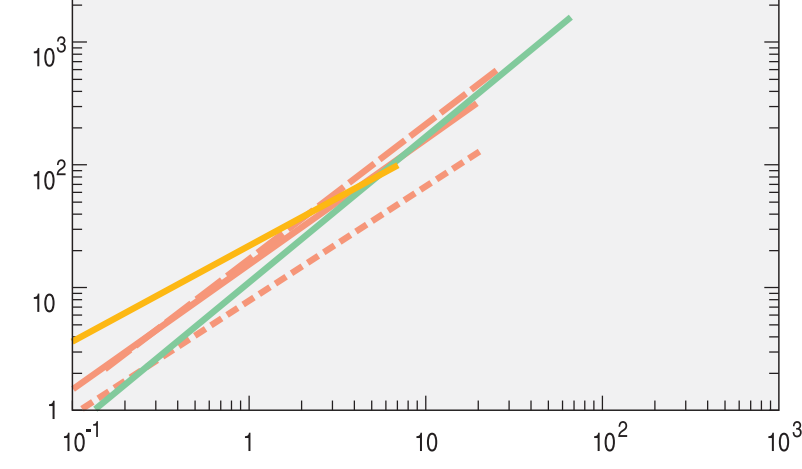

DISCHARGE PER UNIT AREA,

IN CUBIC FEET PER SECOND
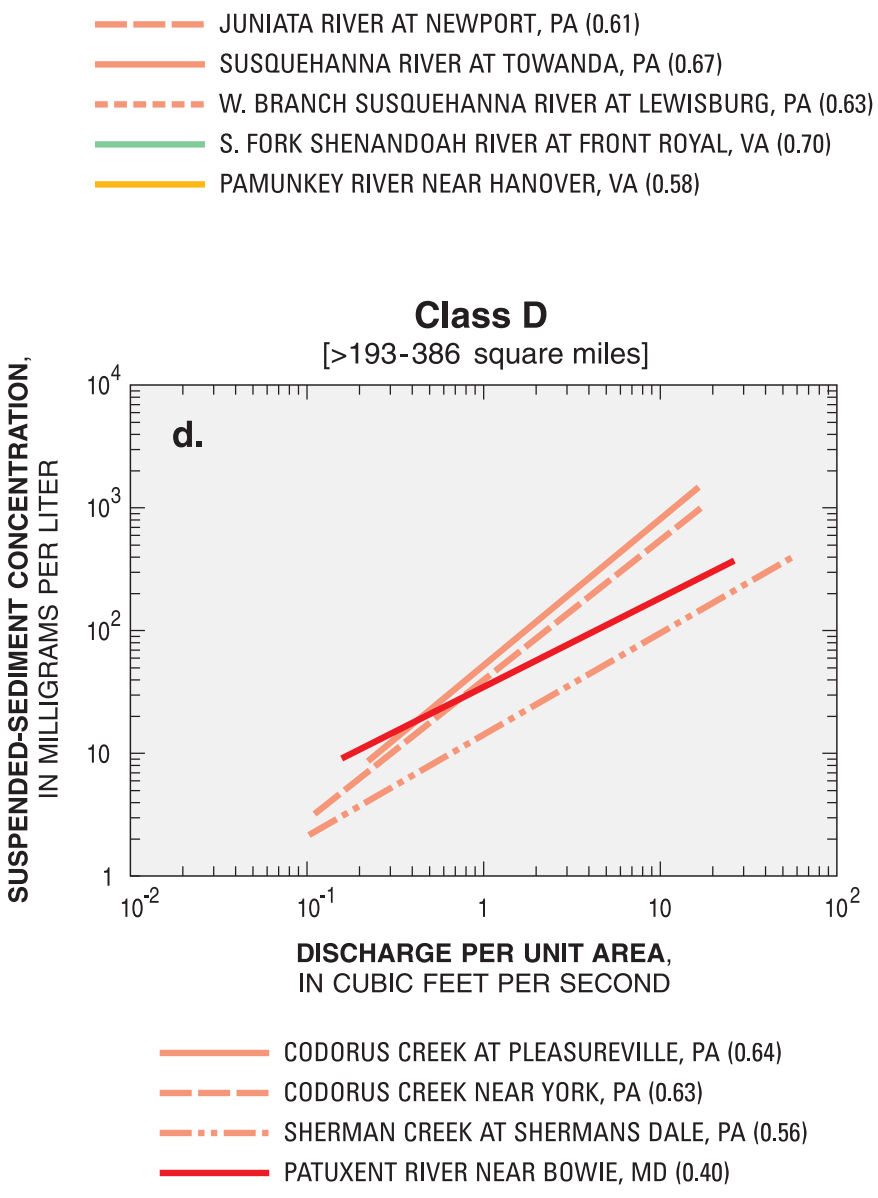

EXPLANATION

CHESAPEAKE BAY WATERSHED BASINS

SUSQUEHANNA RIVER

POTOMAC RIVER

PATUXENT RIVER

YORK RIVER

Figure 12. Sediment-transport curves normalized by drainage area separated into eight classes of drainage area: a. Class A, b. Class $B$, c. Class $\mathrm{C}$, and $\mathbf{d}$. Class $\mathrm{D}$ in the Chesapeake Bay Watershed. ( $R^{2}$ values are shown in parentheses.) 
Class E

[>96.5-193 square miles]

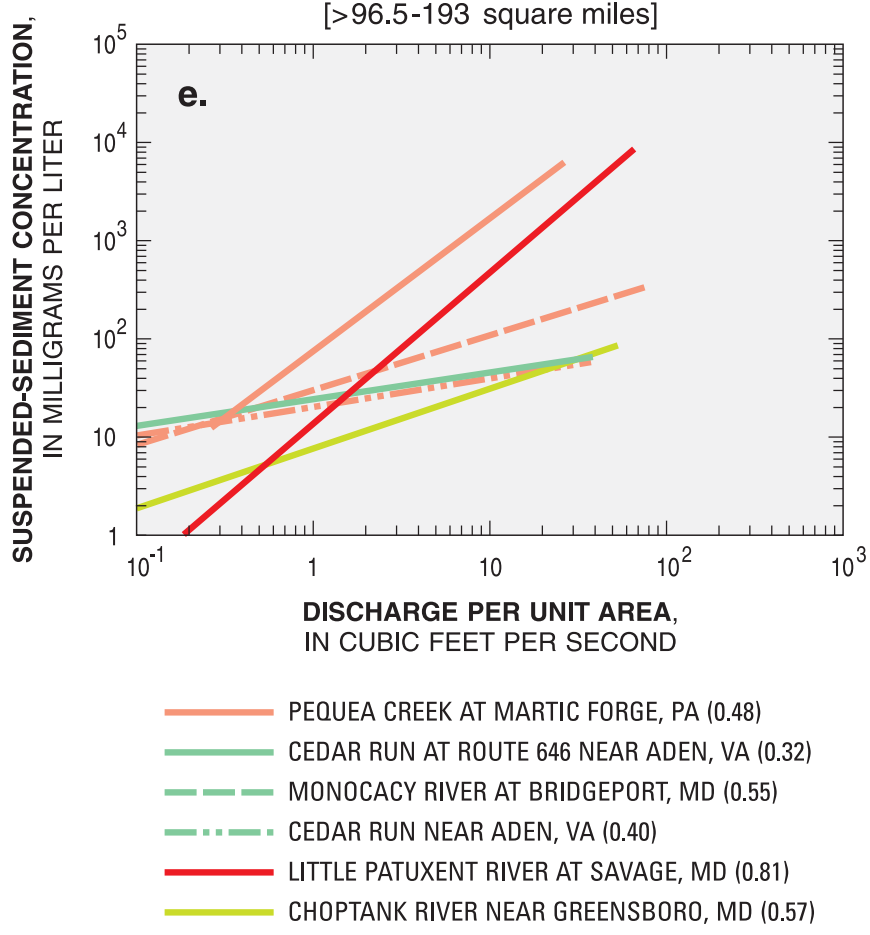

Class G

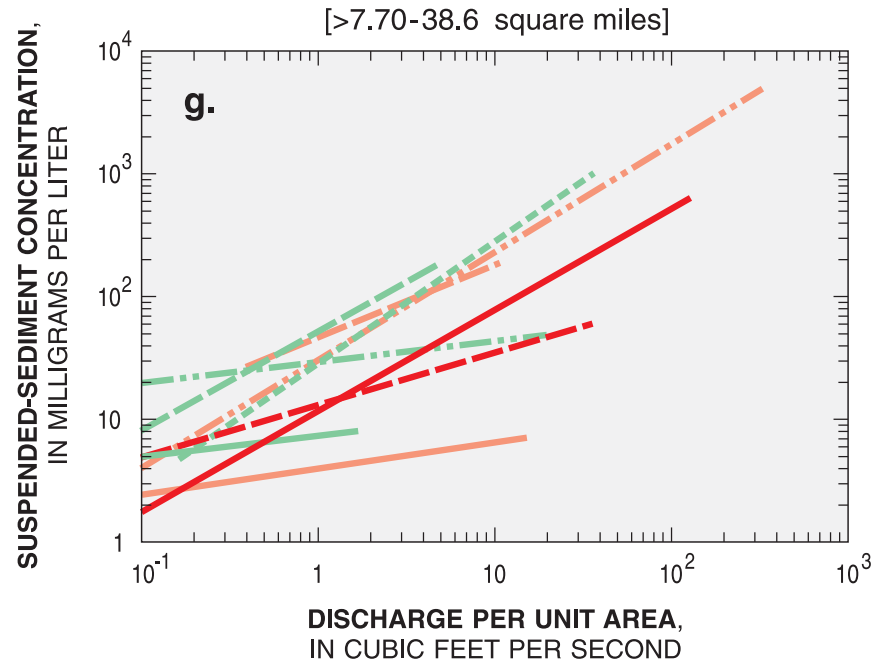

IN CUBIC FEET PER SECOND

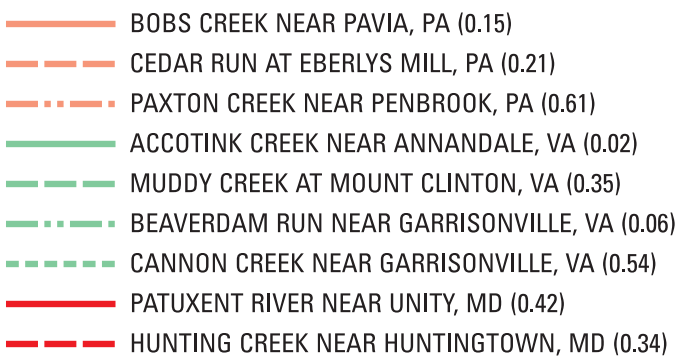

\section{Class F}

[>38.6-96.5 square miles]

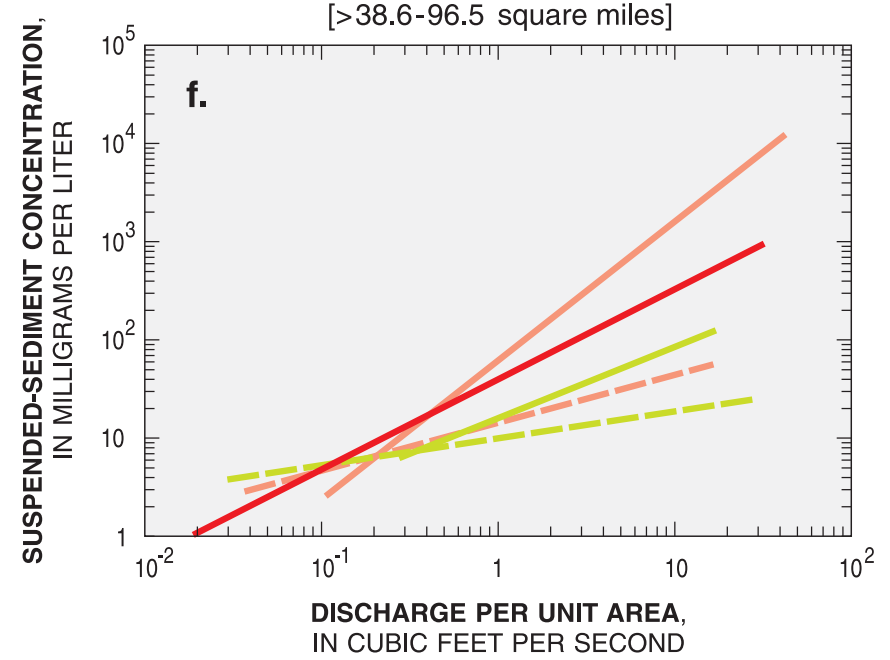

MILL CREEK AT ESHELMAN MILL ROAD NEAR LYNDON, PA (0.73)

- EAST MAHANTANGO CREEK AT KLINGERSTOWN, PA (0.40)

WESTERN BRANCH AT UPPER MARLBORO, MD (0.67)

NANTICOKE RIVER NEAR BRIDGEVILLE, DE (0.24)

- NASSAWANGO CREEK NEAR SNOW HILL, MD (0.19)

\section{Class H}

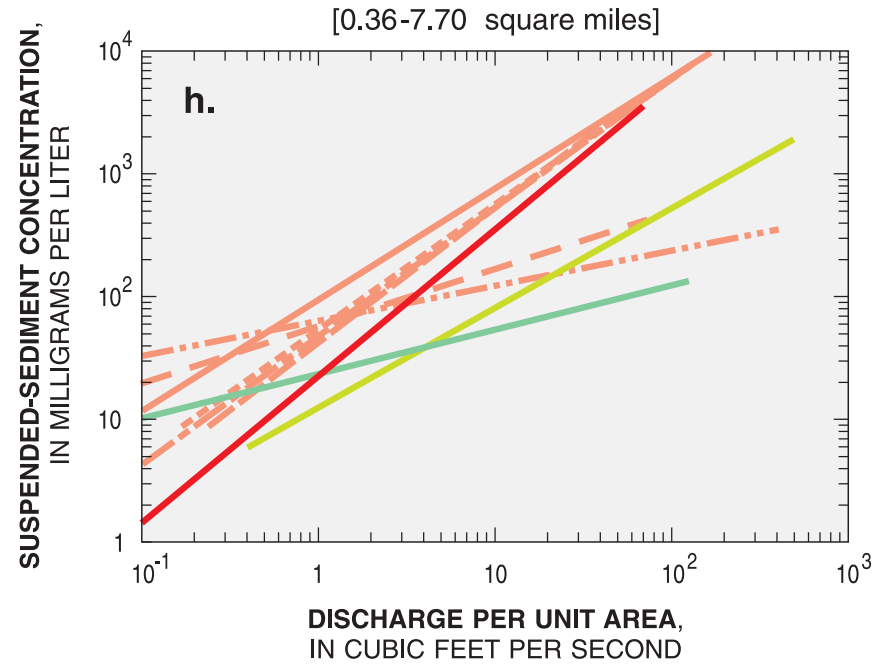

LITTLE CONESTOGA CREEK NEAR CHURCHTOWN, PA (0.63)

- - BIG SPRING RUN NEAR WILLOW STREET, PA (0.32)

- - UNNAMED TRIBUTARY TO BIG SPRING RUN NEAR LAMPETER, PA (0.36)

$m=-m=$ BALD EAGLE CREEK NEAR FAWN GROVE, PA (0.43)

$-\cdots=$ BRUSH RUN, SITE 2, NEAR MCSHERRYSTOWN, PA (0.16)

- - N. FORK UNNAMED TRIBUTARY TO BIG SPRING RUN AT LAMPETER, PA (0.13)

S. FORK QUANTICO CREEK NEAR INDEPENDENT HILL, VA (0.31)

KILLPECK CREEK AT HUNTERSVILLE, MD (0.68)

CHESTERVILLE BRANCH NEAR CRUMPTON, MD (0.56)

\section{EXPLANATION}

\section{CHESAPEAKE BAY WATERSHED BASINS}

SUSQUEHANNA RIVER

POTOMAC RIVER

PATUXENT RIVER

EASTERN SHORE

Figure 12. Sediment-transport curves normalized by drainage area separated into eight classes of drainage area: e. Class $E$, f. Class $F$, g. Class $\mathrm{G}$, and $\mathbf{h}$. Class $\mathrm{H}$ in the Chesapeake Bay Watershed. $\left(R^{2}\right.$ values are shown in parentheses.) -- Continued. 


\section{Summary and Conclusions}

Much of the habitat in the Chesapeake Bay Watershed is degraded because of sediment. Determining potential source areas of sediment in the Watershed is an important component in reduction of erosion and sediment transport. This report describes historical annual suspended-sediment loads, yields, and discharge-weighted concentrations, and instantaneous suspended-sediment concentrations compiled from 65 stations operating from 1952-2002 in the 64,000square-mile Chesapeake Bay Watershed. Suspended-sediment load, yield, and discharge-weighted sediment concentration data were separated into two periods, 1952-84 and 1985-2001. In 1985, the Chesapeake Bay Program began recommending sediment regulations, so 1985 represents an important break in the data. The size of drainage areas for sediment stations where annual suspended-sediment loads were collected ranged from 0.36 to 27,100 square miles. Areas draining 100 to 500 square miles had the most sediment stations operating at any time, and areas draining 50 to 100 square miles had the least sediment stations operating from 1952 through 2001. Suspended-sediment load data compiled for this report were typically computed using two methods, the subdivision method, which was used at dailyload stations, and the linear-regression or ESTIMATOR method, which was used to compute monthly and annual loads. A comparison of both methods for nine stations totaling 36 years of record indicates that the ESTIMATOR method has a tendency to compute higher suspended-sediment loads than the subdivision method.

Average annual suspended-sediment loads are strongly, positively correlated to both drainage area $\left(\mathrm{R}^{2}=0.88\right)$ and average annual mean-daily discharge $\left(\mathrm{R}^{2}=0.88\right)$ for the sediment-collection period (1952-2001). Size of the drainage area shows a weak, inverse relation to both average annual sediment yield $\left(\mathrm{R}^{2}=-0.17\right)$ and average annual dischargeweighted sediment concentration $\left(R^{2}=-0.17\right)$. This inverse relation is expected as more sediment storage sites become available as drainage-area size increases.

The Chesapeake Bay River Input Monitoring Program was established in the mid-1980s to quantify loads and longterm trends in suspended sediment entering the tidal part of the Chesapeake Bay Basin from its nine major tributaries (Appomattox, Choptank, James, Mattaponi, Pamunkey, Patuxent, Potomac, Rappahannock, and Susquehanna). The nine River Input Monitoring stations drain 78 percent of the Chesapeake Bay Watershed, and the data collected at these stations allowed suspended-sediment transport analysis at a large scale. The River Input Monitoring station data for 1985 through 2001 indicated that the Potomac and Susquehanna Rivers had the highest average annual suspended-sediment loads. The Rappahannock and Potomac Rivers had the highest average annual sediment yields and discharge-weighted sediment concentrations. The Choptank, Mattaponi, and Appomattox Rivers had the three lowest average annual sediment loads, sediment yields, and discharge-weighted sediment concentrations.
For stations operating from 1952-84 $(n=43)$, two of the five highest suspended-sediment loads were on the Potomac River (Chain Bridge at Washington, D.C. and at Point of Rocks, Maryland). Three of the five highest average annual suspended-sediment loads from 1952-84 were for stations on the Susquehanna River (at Harrisburg, Pennsylvania; at Sunbury, Pennsylvania; and at Conowingo, Maryland). The highest average annual suspended-sediment loads were for rivers that drain the largest area. The sediment load at the Susquehanna River at Conowingo is affected by three upstream reservoirs that reduce the delivery of sediment to this station; if the reservoirs were not in place, the average annual suspended-sediment loads would likely be higher.

Similar rankings were produced by normalizing average annual suspended-sediment loads by drainage area to produce an average annual sediment yield and normalizing each annual suspended-sediment load by annual runoff to produce an average annual discharge-weighted sediment concentration. The similarity in ranking is because runoff is highly correlated to drainage area. The highest sediment yields and discharge-weighted sediment concentrations from 1952-84 were for streams draining the suburban Washington, D.C. area (Snakeden Branch at Reston, Virginia; Smilax Branch at Reston, Virginia; and Northwest Branch Anacostia River near Colesville, Maryland). The lowest average annual sediment yields and discharge-weighted sediment concentrations for stations with data collected through 1984 were at Young Womans Creek near Renovo, Pennsylvania; Choptank River near Greensboro, Maryland; and the Pamunkey River near Hanover, Virginia. The high sediment yields for streams draining the metropolitan Washington, D.C. region may reflect urbanization and construction practices that were occurring in these basins when the stations were operating (1963-78).

At stations operating from 1985 through $2001(\mathrm{n}=35)$, four of the five highest average suspended-sediment loads were the same as for stations operating from 1952-84 (Potomac River at Chain Bridge at Washington, D.C.; Potomac River at Point of Rocks, Maryland; Susquehanna River at Marietta, Pennsylvania; and Susquehanna River at Conowingo, Maryland). Four of the six highest average annual sediment yields and discharge-weighted sediment concentrations for the period 1985-2001 were for stations in Lancaster County, Pennsylvania, draining to the Conestoga River, a tributary to the Susquehanna River (Conestoga River at Conestoga, Pennsylvania; Little Conestoga Creek near Churchtown, Pennsylvania; Little Conestoga Creek site 3A, near Morgantown, Pennsylvania; and Mill Creek at Eshelman Mill Road near Lyndon, Pennsylvania). The Rappahannock River near Fredericksburg, Virginia, had the third highest average annual sediment yield and dischargeweighted sediment concentration, and Raystown Branch Juniata River at Saxton, Pennsylvania, a tributary of the Susquehanna River, had the fifth highest average annual sediment yield and discharge-weighted sediment concentration.

Percentiles of suspended sediment $\left(10^{\text {th }}, 50^{\text {th }}\right.$, and $\left.90^{\text {th }}\right)$ 
were examined for 51 stations with at least 3 years of data and at least 10 samples in a given year. The four highest suspended-sediment concentrations at the $10^{\text {th }}$ percentile (ranging from 18 to 53 milligrams per liter) were in rivers draining to the Susquehanna River in Pennsylvania (Brush Run, site 2, near McSherrystown; Codorus Creek at Pleasureville; Conestoga River at Conestoga; and Little Conestoga Creek near Churchtown. The $10^{\text {th }}$ percentile of suspended-sediment concentration reflects low-flow conditions. Three of the five sediment stations with the highest $50^{\text {th }}$ percentile of suspended-sediment concentration (ranging from 186 to 548 milligrams per liter) included the same stations in the Susquehanna River Basin as at the $10^{\text {th }}$ percentile (Codorus Creek at Pleasureville; Conestoga River at Conestoga; and Little Conestoga Creek near Churchtown), another station in Pennsylvania (Paxton Creek near Penbrook), and one station in Maryland draining to the Patuxent River (Killpeck Creek at Huntersville, Maryland). At the $90^{\text {th }}$ percentile, the five highest suspended-sediment concentrations (ranging from 1,520 to 3,140 milligrams per liter) were for stations draining the Susquehanna River Basin in Pennsylvania (Little Conestoga Creek near Churchtown; Pequea Creek at Martic Forge; Bald Eagle Creek near Fawn Grove; and Mill Creek at Eshelman Mill Road near Lyndon) and Killpeck Creek at Huntersville, Maryland, in the Patuxent River Basin.

Sediment-transport curves generated for eight classes of drainage areas for 51 stations show that the Susquehanna River Basin had the highest suspendedsediment concentrations in five of the eight classes:

- Class C [>386-965 square miles]_Conestoga River,

- Class D [>193-386 square miles]_Codorus Creek,

- Class E [>96.5-193 square miles] Pequea Creek,

- Class F [>38.6-96.5 square miles]-Mill Creek, and

- Class H [0.36-7.70 square miles]—Little Conestoga Creek.

Three of these five stations drain to the Conestoga River (Little Conestoga Creek near Churchtown, Pennsylvania; Mill Creek near Eshelman Mill Road near Lyndon, Pennsylvania; and Conestoga River at Conestoga, Pennsylvania). Cannon Creek near Garrisonville, Virginia, showed the highest suspended-sediment concentrations at high discharges for Class $\mathrm{G}$ (>7.70-38.6 square miles).

Suspended-sediment loads are highly correlated with area, and therefore, rankings of loads for stations in the Chesapeake Bay Watershed will reflect drainage-area size. Normalizing suspended-sediment loads by drainage area and annual runoff provides additional information on erosion and sediment delivery in each basin. In general, the highest average annual sediment yields were in rivers draining to the Susquehanna River. In the Susquehanna River Basin, the highest sediment yields and discharge-weighted sediment concentrations were in the Conestoga River Basin. The Conestoga River Basin drains primarily agricultural areas, but other sources of sediment, such as from bank erosion, also may be important in this basin.

\section{References Cited}

American Society for Testing and Materials (ASTM), 1999, D 3977-97, Standard test method for determining sediment concentration in water samples: Annual Book of Standards Water and Environmental Technology, 1999, Volume 11.02, p. 389-394.

Belval, D.L., and Sprague, L.A., 1999, Monitoring nutrients in the major rivers draining to Chesapeake Bay: U.S. Geological Survey Water-Resources Investigations Report 99-4238, 8 p.

Brown, L., Pavich, M.J., Hickman, R.E., Klein, J., and Middleton, R., 1988, Erosion of the eastern United States observed with ${ }^{10} \mathrm{Be}$ : Earth Surface Processes and Landforms, v. 13, p. 441-457.

Cohn, T.A., Caulder, D.L., Gilroy, E.J., Zynjuk, L.D., and Summers, R.M., 1992, The validity of a simple statistical model for estimating fluvial constituent loads: An empirical study involving nutrient loads entering Chesapeake Bay: Water Resources Research, v. 289, no. 9, p. 2,353-2,363.

Cohn, T.A., DeLong, L.L., Gilroy, E.J., Hirsh, R.M., and Wells, D.K., 1989, Estimating constituent loads: Water Resources Research, v. 25, no. 5, p. 937-942.

Darrell, L.C., Majedi, B.F., Lizarraga, J.S., and Blomquist, J.D., 1999, Nutrient and suspendedsediment concentrations, trends, loads, and yields from the nontidal part of the Susquehanna, Potomac, Patuxent, and Choptank Rivers, 1985-96: U.S. Geological Survey Water-Resources Investigations Report 98-4177, 38 p.

Edwards, T.K., and Glysson, G.D., 1988, Field methods for measurement of fluvial sediment: U.S. Geological Survey Open-File Report 86-531, 118 p.

Glysson, G.D., 1987, Sediment-transport curves: U.S. Geological Survey Open-File Report 87-218, 47 p.

Gray, J.R., Glysson, G.D., Turcios, L.M., and Schwarz, G.E., 2000, Comparability of suspended-sediment concentration and total suspended solids data: U.S. Geological Survey Water-Resources Investigations Report 00-4191, 14 p.

Guy, H.P., 1964, An analysis of some storm-period variables affecting stream sediment transport: U.S. Geological Survey Professional Paper 462-E, 46 p.

1969, Laboratory theory and methods for sediment analysis: U.S. Geological Survey Techniques of WaterResources Investigations, book 3, chap. C1, $55 \mathrm{p}$.

Guy, H.P., and Ferguson, G.E., 1962, Sedimentation in small reservoirs due to urbanization: Journal of Hydraulics Division of the American Society of Civil Engineers, no. HY2, Proceedings Paper 3070, v. 88, p. 27-37. 
Hainly, R.A., and Loper, C.A., 1997, Water-quality assessment of the Lower Susquehanna River Basin, Pennsylvania and Maryland: Sources, characteristics, analysis, and limitations of nutrient and suspendedsediment data, 1975-90: U.S. Geological Survey WaterResources Investigations Report 97-4209, 138 p.

Helsel, D.R., and Hirsch, R.M., 1992, Statistical methods in water resources: Studies in Environmental Science 49: Elsevier Science Publishers B.V., Netherlands, 522 p.

Horowitz, A.J., 2003, An evaluation of sediment rating curves for estimating suspended sediment concentrations for subsequent flux calculations: Hydrological Processes, v. 17, p. 3,387-3,409.

Jones, B.L., 1966, Effects of agricultural conservation practices on the hydrology of Corey Creek Basin, Pennsylvania, 1954-60: U.S. Geological Survey Water-Supply Paper 1532-C, 55 p.

Knott, J.M., Sholar, C.J., and Matthes, W.J., 1992, Quality assurance guidelines for the analysis of sediment concentration by U.S. Geological Survey Sediment Laboratories: U.S. Geological Survey Open-File Report 92-33, $22 \mathrm{p}$.

Koltun, G.F., Gray, J.R., and McElhone, T.J., 1994, User's manual for SEDCALC, a computer program for computation of suspended-sediment discharge: U.S. Geological Survey Open-File Report 94-459, 46 p.

Langland, M.J., and Hainly, R.A, 1997, Changes in bottom-surface elevations in three reservoirs on the lower Susquehanna River, Pennsylvania and Maryland, following the January 1996 flood: Implications for nutrient and sediment loads to the Chesapeake Bay: U.S. Geological Survey Water-Resources Investigations Report 97-4138, 34 p.

Langland, M.J., Lietman, P.L., and Hoffman, S., 1995, Synthesis of nutrient and sediment data for watersheds within the Chesapeake Bay drainage basin: U.S. Geological Survey Water-Resources Investigations Report 95-4233, $121 \mathrm{p}$.

Meade, R.H., Yuzyk, T.R. and Day, T.J., 1990, Movement and storage of sediment in rivers of the United States and Canada, in Wolman, M.G., and Riggs, H.C., eds., Surface-water hydrology: Geological Society of America, The Geology of North America, v. O-1, p. 255-280.

Porterfield, G., 1972, Computation of fluvial-sediment discharge: U.S. Geological Survey Techniques of Water-Resources Investigations, book 3, chap. C3, 66 p.

Roberts, W. P., and Pierce, J. W., 1976, Deposition in Upper Patuxent Estuary, Maryland, 1968-1969: Estuarine and Coastal Marine Science, v. 4, p. 267-280.

Schumm, S.A., 1977, The fluvial system: New York, Wiley, $338 \mathrm{p}$.
Simon, A., Kuhnle, R., Knight, S., and Dickerson, W., 2001, Reference and enhanced rates of suspendedsediment transport for use in developing clean-sediment TMDL's: Examples from Mississippi and the Southeastern United States, in Proceedings of the American Society of Civil Engineers Conference on Wetlands Engineering and River Restoration, Reno, NV, $10 \mathrm{p}$.

Troendle, C.A., Rosgen, D.L., Ryan, S.E., Porth, L.S., and Nankervis, J.M., 2002, Developing a "reference" sediment transport relationship: Proceedings of the Seventh Federal Interagency Sedimentation Conference, Reno, Nevada, Chapter II, p. 73-80.

U.S. Geological Survey, Water resources data reports: Maryland (1962-93), [variously paged] Water resources data reports, New York (197580), [variously paged] Water resources data reports, Pennsylvania (1952-86), [variously paged]. Water resources data reports, Virginia (1952-99), [variously paged]. 2003, Suspended-sediment database, accessed June 23, 2003 at http://webserver.cr.usgs.gov/sediment

Walling, D.E., 1977, Assessing the accuracy of suspended sediment-rating curves for a small basin: Water Resources Research, v. 13, no. 3, p. 531-538.

1983, The sediment delivery problem: Journal of Hydrology, v. 65, p. 209-237.

Walling, D.E., and Webb, B.W., 1982, Sediment availability and the prediction of storm-period sediment yields: International Association of Hydrological Sciences, Publication No. 137, p. 327-337.

Williams, K.F., and Reed, L.A., 1972, Appraisal of stream sedimentation in the Susquehanna River Basin: U.S. Geological Survey Water-Supply Paper 1532-F, $24 \mathrm{p}$.

Wolman, M.G., 1967, A cycle of sedimentation and erosion in urban river channels: Geografiska Annaler, v. 49A, p. 385-395. 